\title{
ESTUDO DA ELETRORRETINOGRAFIA DO CAMUNDONGO MODELO DE ALZHEIMER (3xTg-AD)
}

Dissertação apresentada ao Instituto de Psicologia da Universidade de São Paulo, como parte dos requisitos para obtenção do grau de Mestre em Ciências

Área de concentração: Neurociências e Comportamento

Orientadora: Profa. Dra. Dora Selma Fix Ventura 
AUTORIZO A REPRODUÇÃO E DIVULGAÇÃO TOTAL OU PARCIAL DESTE TRABALHO, POR QUALQUER MEIO CONVENCIONAL OU ELETRÔNICO, PARA FINS DE ESTUDO E PESQUISA, DESDE QUE CITADA A FONTE.

\section{Catalogação na publicação}

Biblioteca Dante Moreira Leite

Instituto de Psicologia da Universidade de São Paulo

Ioshimoto, Gabriela Lourençon.

Estudo da eletrorretinografia do camundongo modelo de Alzheimer (3xTg-AD) / Gabriela Lourençon loshimoto; orientadora Dora Selma Fix Ventura. -- São Paulo, 2010.

$78 \mathrm{f}$.

Dissertação (Mestrado - Programa de Pós-Graduação em Psicologia. Área de Concentração: Neurociências e Comportamento) Instituto de Psicologia da Universidade de São Paulo.

1. Eletrorretinografia 2. Camundongos 3. Modelos animais 4. Doença de Alzheimer I. Título.

RE79.E4 
Nome: loshimoto, G. L.

Título: Estudo da eletrorretinografia do camundongo modelo de Alzheimer (3xTg-AD)

Dissertação apresentada ao Instituto de Psicologia da Universidade de São Paulo para obtenção do título de Mestre em Neurociências e Comportamento.

Aprovado em:

Banca Examinadora

Prof. Dr.

Instituição: Assinatura:

Prof. Dr.

Instituição: Assinatura:

Prof. Dr.

Instituição: Assinatura:

Prof. Dr. Instituição: Assinatura:

São Paulo 2010 
ESTUDO DA ELETRORRETINOGRAFIA DO CAMUNDONGO MODELO DE ALZHEIMER (3xTg-AD)

Objetivo: Avaliar eletrofisiologicamente a função da retina do camundongo modelo de Alzheimer (3xTg-AD) comparando com seu controle (b6;129-PS1) em um estudo longitudinal com seis idades $(2,4,6,8,10$ e 12 meses).

Métodos: Eletrorretinogramas (ERGs) foram registrados em 44 camundongos 3xTg-AD e em 23 controles, após administrada anestesia. Para o registro foi colocado um eletrodo de lente de contato sobre a córnea, um eletrodo de referência na cabeça e um terra na cauda. Em sessão de 30-40min de duração foram expostos ao seguinte protocolo de estimulação: 1) Adaptação ao escuro seguida de flashes nas intensidades: 0,003; 0,03; 0,3; 3 e 30 cd.s $/ \mathrm{m}^{2} ; 2$ ) Estimulação periódica $\left(30 \mathrm{~cd} . \mathrm{s} / \mathrm{m}^{2}\right.$ ) nas freqüências de 12,18 , e $30 \mathrm{~Hz}$, sob luz de fundo (30 $\left.\mathrm{cd} / \mathrm{m}^{2}\right)$.

Resultados: Os ERGs mostraram dois tipos de respostas escotópicas tanto no grupo dos camundongos controles (b6;129- PS1) quanto nos modelos de Alzheimer. $13 \%$ dos camundongos controles e $72 \%$ dos modelos de $A D$ apresentaram ERGs com potenciais oscilatórios presentes e tempo implícito da onda-b dentro da faixa esperada $(45,31 \pm 6,74$ $\mathrm{ms})$, enquanto no restante dos grupos, O ERG apresentou latência da onda- $b$ muito aumentada $(111,73 \pm 22,56 \mathrm{~ms})$ e potenciais oscilatórios ausentes. Devido a estes resultados, os grupos controle e experimental foram subdivididos em: b6;129 com OP, b6;129 sem OP; 3xTg-AD com OP e 3xTg-AD sem OP. Também foi incluído um grupo controle adicional constituído por 9 camundongos C57/B6. Comparando os cinco grupos, nenhuma diferença foi encontrada em relação à amplitude e à latência da onda- $a$. A amplitude da onda- $b$ também foi semelhante para todos, ao contrário da latência para atingir o pico da onda-b dos grupos b6;129 sem OP e 3xTg-AD sem OP, que se apresentou duas vezes maior do que nos grupos com OP. As amplitudes dos cinco potenciais oscilatórios foram medidas individualmente e não mostraram diferenças entre os controles e os 3xTg-AD. Para o estímulo periódico, a amplitude do 1 o harmônico dos grupos com OP mostrou clara diferença entre os grupos controle e o $3 \times T g-A D$, tanto em $12 \mathrm{~Hz}$ como em $18 \mathrm{~Hz}$. Os resultados dos dois grupos controle b6;129 e C57/B6 mantiveram-se muito próximos. Os grupos sem OP mantiveram-se sempre próximos a $10 \mu \mathrm{V}$ para as três freqüências de estimulação e mostraram atraso na diferença de fase média do 10 harmônico em 18 e $30 \mathrm{~Hz}$, indicando maior lentidão de resposta, quando comparados aos primeiros.

Conclusão: $O$ camundongo 3xTg-AD e seu controle $(b 6 ; 129)$ apresentam uma variante lenta e sem OPs do ERG escotópico em parte da população. Células bipolares, amácrinas e ganglionares podem estar alteradas nesses subgrupos (b6;129 sem OP e 3xTg-AD sem OP). Os grupos controle e 3xTg-AD com OPs diferiram quanto à amplitude de resposta à estimulação intermitente, diferença essa que implica em menor capacidade de processamento temporal para o modelo de AD. Sugerimos que as células bipolares de cones podem estar alteradas nos modelos de $A D$ devido às amplitudes mais baixas dos $1^{\text {os }}$ harmônicos desse grupo. 
STUDY OF THE ELECTRORETINOGRAM OF THE ALZHEIMER`S DISEASE MODEL MOUSE (3xTg$A D)$

Objective: To evaluate electrophysiologically the function of the retina of the Alzheimer model mouse (3xTg-AD) comparing it with its control (b6;129-PS1) in a longitudinal study at six ages $(2,4,6,8,10$ e 12 months)

Methods: Electroretinograms (ERGs) were recorded in 44 anesthetized mice 3xTg-AD and in 23 controls, with a contact lens electrode placed on the cornea, a reference electrode on the head and a ground on the tail. During a $30-40 \mathrm{~min}$ duration session the mice were exposed to the following stimulation protocol: 1) Scotopic response - Dark adaptation followed by flashes at the following intensities: 0,$003 ; 0,03 ; 0,3 ; 3$ e $30 \mathrm{~cd} . \mathrm{s} / \mathrm{m}^{2} ; 2$ ) Periodic stimulation $\left(30 \mathrm{~cd} . \mathrm{s} / \mathrm{m}^{2}\right.$ ) at the temporal frequencies of 12,18 , e $30 \mathrm{~Hz}$, under background light (30 $\left.\mathrm{cd} / \mathrm{m}^{2}\right)$.

Results: The ERGs showed two types of scotopic responses, which ocurred in both the control mice (b6;129- PS1) and the Alzheimer's models (3xTg-AD). 13\% of the controls and $72 \%$ of the Alzheimer's models mice presented ERGs with oscillatory potentials (OPs) and bwave implicit times within the expected range $(45,31 \pm 6,74 \mathrm{~ms})$, while for the other groups the ERG presented a very delayed b-wave latency $(111,73 \pm 22,56 \mathrm{~ms})$ and absence of OPs. Given these results, the control and experimental groups were subdivided into: b6;129 with OPs, b6;129 without OPs; 3xTg-AD with OPs e 3xTg-AD without OPs. An additional control group with 9 mice C57/B6 was included. Comparing the five groups, no difference was found in a-wave amplitude and latency. The b-wave amplitude also did not differ among the groups, but the latency of the b-wave for the groups b6;129 without OPs and 3xTg-AD without OPs, was twice as long as in the groups with OPs. The amplitudes of the five OPs, measured individually, did not show differences between controls and 3xTg-AD groups. For the periodic stimulation the amplitude of the first harmonic of the Fourier transform of the groups with OPs showed a clear difference between the control and the 3xTg-AD groups, both for the $12 \mathrm{~Hz}$ and for the $18 \mathrm{~Hz}$ stimuli. The results of the two control groups (b6;129 and $\mathrm{C} 57 / \mathrm{B} 6)$ were very close. The groups without OPs had responses always close to $10 \mu \mathrm{V}$ for the three frequencies of stimulation and showed phase delay for the first harmonic, indicating response slowing, compared to the other groups.

Conclusions: We found that a sub-group of both triple transgenic (3xTg-AD) and control mice (b6;129) manifest strikingly slow scotopic ERGs that lack OPs. We hypothesize that these response feature may reflect alterations in bipolar, amacrine and ganglion cells. The subgroup of triple transgenic and control mice that exhibited OPs differed in their response to flicker. Alzheimer model had significantly lower flicker-response amplitudes than the controls, suggesting impaired retinal temporal processing. We propose that the flicker results are consistent with alteration in cone bipolar cells in the Alzheimer model mice. 


\section{SUMÁRIO}

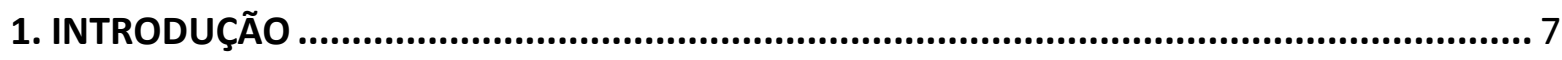

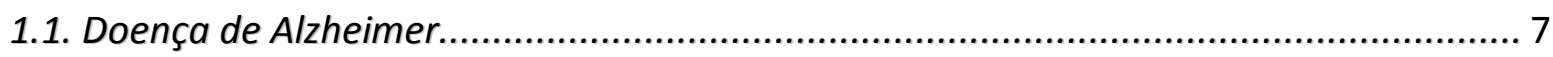

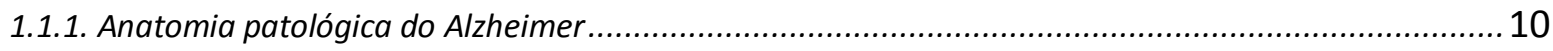

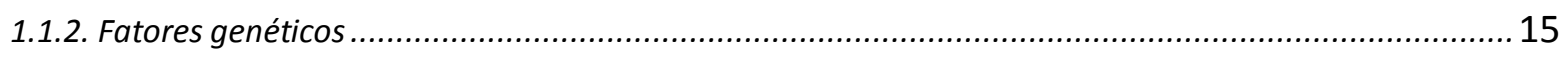

1.2. O sistema visual em pacientes com Alzheimer........................................................ 16

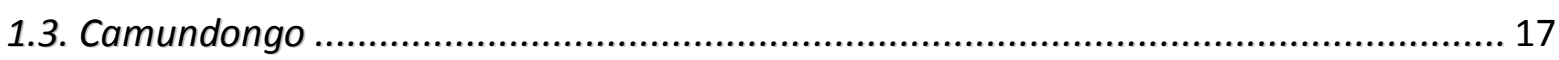

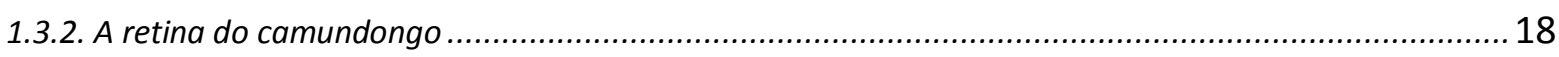

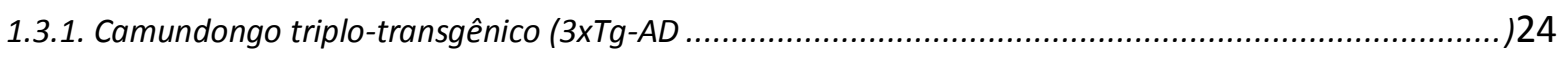

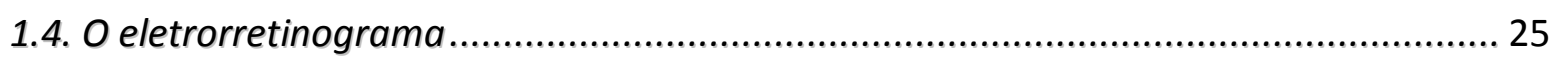

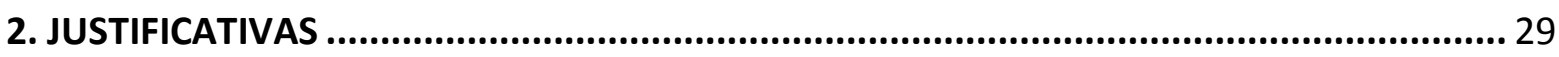

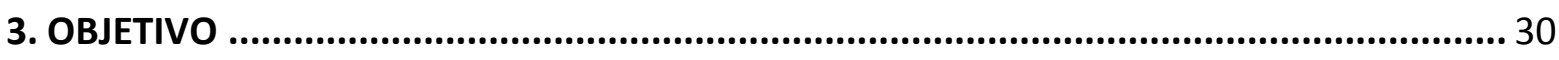

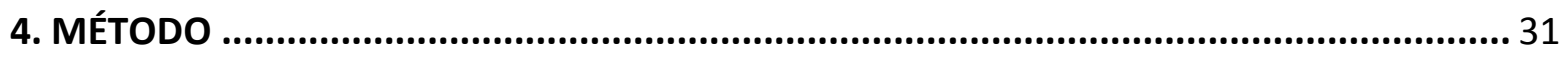

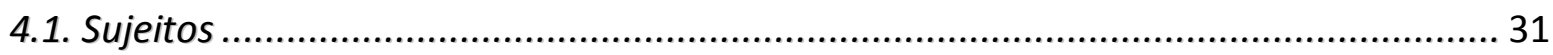

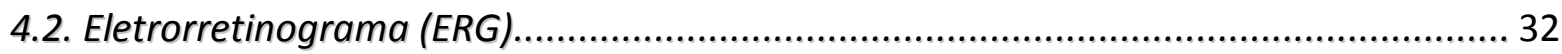

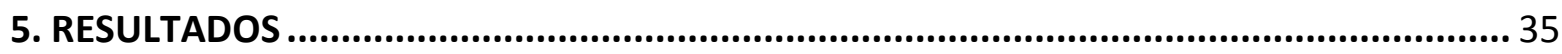

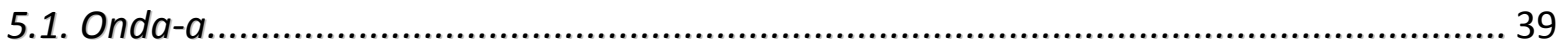

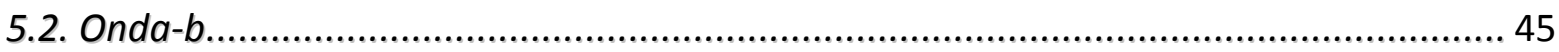

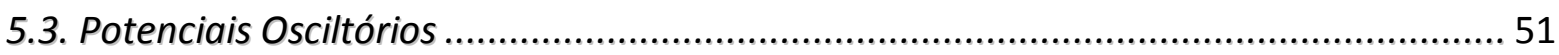

5.4. Respostas a diferentes freqüências temporais de estimulação (flicker)....................... 52

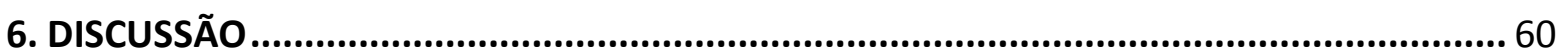

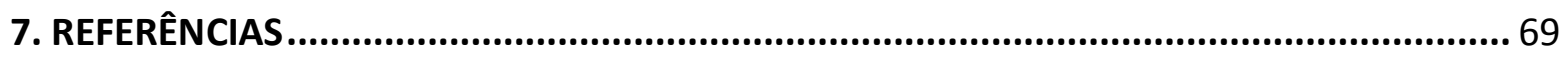




\section{INTRODUÇÃO}

\subsection{Doença de Alzheimer}

A Doença de Alzheimer (DA) é uma desordem neurodegenerativa progressiva do sistema nervoso central, de etiologia ainda não esclarecida e é a forma mais comum de demência em pessoas idosas no Brasil e no mundo. Em 1907, pela primeira vez, o médico Alois Alzheimer já descrevia que acúmulos de algumas proteínas e lesões no cérebro eram indicativos histopatológicos desta doença demencial (Möller, 1998; Mucke, 2009; Perrin et al, 2009).

Segundo o Instituto Brasileiro de Geografia e Estatística (www.ibge.gov.br), na década de 80, a proporção de idosos com 65 anos era de cinco milhões de pessoas, e, em 2050, será de sessenta milhões (figura 1).

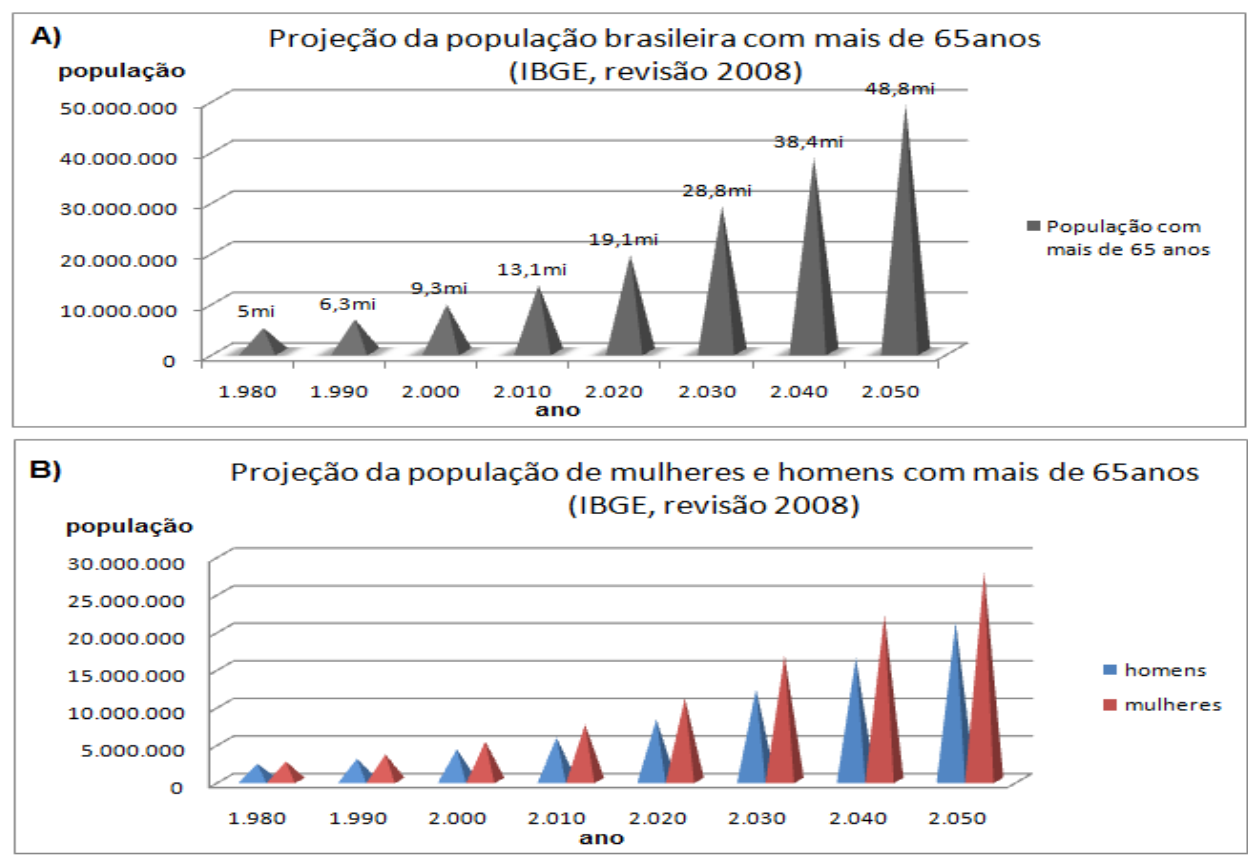

Figura 1. A) Projeção da população idosa brasileira. B) Projeção da população idosa feminina e masculina (www.ibge.gov.br).

Estimativas sugerem que esta doença afete mais de doze milhões de pessoas no mundo (Chaimowicz, 1997; Ferri et al, 2005). No Brasil, Herrera e colaboradores fizeram um 
estudo populacional em Catanduva (interior de São Paulo) com aproximadamente $25 \%$ dos idosos deste município. Eles encontraram uma prevalência de demência semelhante à literatura: 7,1\% de casos de demência em uma população de 1.656 indivíduos com idade igual ou maior a 65 anos (Herrera et al, 1998).

Associando este estudo em Catanduva com os dados do IBGE, extrapola-se que atualmente temos 930 mil portadores de Alzheimer e em 2050, teremos 4 milhões.

Um estudo brasileiro realizado por Cintra e colaboradores em 2009 avaliou a taxa de cobertura do Programa Público de Tratamento da Doença de Alzheimer em 2008 através do levantamento de dados do sistema público (como o IBGE e SUS). Foram encontrados 799.220 pacientes portadores de Alzheimer e um gasto de $\mathrm{R} \$ \mathbf{9 9 . 7 4 7 . 3 5 6 , 5 3}$ pelo Ministério da Saúde para apenas 47.886 pacientes (www.abraz.com.br).

Assim como as outras síndromes demenciais, a Doença de Alzheimer implica em grandes transtornos mentais, físicos e psicológicos; sua instalação é insidiosa e a evolução é lenta, geralmente, arrasta-se por mais de dois anos (Aprahamian, 2009), podendo ser classificada como pré-senil, quando o início da doença ocorre antes dos 65 anos de idade, ou senil, quando ocorre após os 65 anos (Dalgalarrondo, 2000).

Os principais sintomas encontrados em pacientes com Doença de Alzheimer leve a moderada são: prejuízo na memória recente; dano global do funcionamento intelectual (déficit no julgamento e raciocínio lógico); diminuição do QI (quociente de inteligência); perda na fluência verbal e redução na linguagem variável (dificuldade de nomear). Em pacientes moderados a avançados, além destas disfunções cognitivas, há um aumento na atividade motora grosseira, alteração no ciclo de sono, disforia e irritabilidade (Parks et al, 1993).

Apenas com um exame post mortem detalhado do cérebro pode-se fornecer um diagnóstico incontestável para a Doença de Alzheimer (Mucke, 2009) e, segundo a Academia Brasileira de Neurologia (Nitrini, 2005 a; Nitrini, 2005 b) o diagnóstico in vivo da Doença de Alzheimer deve ser estabelecido por exames laboratoriais e clínicos, os quais estão baseados nos critérios da Associação Psiquiátrica Americana (DSM) e no NINCDS-ADRDA (National Institute of Neurological and Communicative Disorders and Stroke and the Alzheimer's 
Disease and Related Disorders Association). Estes exames devem excluir outras possíveis causas para a demência (aquelas que são conseqüências de doenças vasculares ou associadas às demências subcorticais), além de excluir aquela que é comumente encontrada em idades mais avançadas (Dalgalarrondo, 2000; Nitrini, 2005 a; Nitrini, 2005 b).

O quadro abaixo mostra as principais funções cognitivas avaliadas em pacientes com suspeitas de Alzheimer (Nitrini, 2005 b, Dalgalarrondo, 2000):

\begin{tabular}{|ll|}
\hline \multicolumn{1}{|c|}{ Aspectos clínicos debilitados } & \multicolumn{1}{c|}{ Características } \\
\hline Memória & $\begin{array}{l}\text { O déficit de memória é uma das primeiras } \\
\text { características apresentadas pelo paciente } \\
\text { com DA. }\end{array}$ \\
\hline Múltiplas funções cognitivas & $\begin{array}{l}\text { Disfasias, afasias, agnosias, apraxias e } \\
\text { dificuldades na aprendizagem e } \\
\text { julgamento. }\end{array}$ \\
\hline Funções executivas associadas ao lobo & Perda do pensamento abstrato, \\
frontal & planejamento, diminuição da fluência \\
& verbal. \\
\hline Personalidade & Perda do controle emocional. \\
\hline Percepção visual & $\begin{array}{l}\text { O paciente se sente disperso e } \\
\text { desorientado em sua própria casa e/ou } \\
\text { apresenta dificuldade em reconhecer os } \\
\text { rostos dos familiares }\end{array}$ \\
\hline Sintomas psiquiátricos associados & Paranóide, depressão, ansiedade, \\
& alucinações e agressividade. \\
\hline
\end{tabular}

Os exames laboratoriais recomendados pelo Departamento Científico de Neurologia Cognitiva e do Envelhecimento da Academia Brasileira de Neurologia (Nitrini, 2005 a) são:

1) Hemograma: exames laboratoriais de dosagem de hormônio estimulante da tireóide (TSH), nível sérico de vitamina B12, reações sorológicas para sífilis e, em pacientes com idade inferior a 60 anos, sorologia para HIV.

2) Exame do líquido cefalorraquidiano: pode identificar infecções do sistema nervoso central e doenças neoplásicas e inflamatórias.

3) Exames de neuroimagem: a tomografia computadorizada e a ressonância magnética do crânio podem excluir outras causas de demência. 
4) PET (pósitron emission tomography) e SPECT (single-photon Emission computed tomography): estes exames indicam a degeneração e disfunção neuronal em pacientes com DA (Parks, 1993).

Outros exames mais sofisticados podem ser realizados nos grandes centros clínicos do Brasil, mas, como as condições básicas de saúde no nosso país ainda não são as ideais, estes exames mais avançados não alcançam a população geral e a melhor e principal ferramenta para diagnosticar o Alzheimer é a investigação clínica com anamneses e avaliações das funções cognitivas de pacientes sob maior suspeita (Nitrini, 2005(a)).

Vários estudos demonstraram que alguns fatores podem ser responsáveis por aumentar o risco da demência na Doença de Alzheimer:

- alterações genéticas, como as mutações do gene da proteína precursora do amilóide (cromossomo 21), dos genes das presenilinas 1 e 2 (cromossomos 14 e 1, respectivamente), assim como o polimorfismo da apolipoproteína E (cromossomo 19) (Dawbarn \& Allen, 1995);

- história familiar, uma vez que gêmeos idênticos apresentam concordância para Alzheimer de $40 \%$ aproximadamente (Nee, 1987);

- síndrome de Down, seus portadores apresentam expressão elevada do gene da proteína precursora do amilóide localizado no cromossomo 21 (Goldgaber et al, 1987);

- nível de escolaridade, pois, no estudo de Herrera na cidade de Catanduva, em indivíduos com oito anos ou mais de escolaridade a prevalência foi de $3,5 \%$, enquanto que nos analfabetos foi de 12,2\% (Herrera et al, 1998);

Além disso, trauma cranioencefálico, sexo feminino e etnia caucasiana também podem ser considerados fatores de risco para o Alzheimer (Aprahamian, 2009).

\subsubsection{Anatomia patológica do Alzheimer}

Em 1906, após a autópsia da primeira paciente suspeita de ser portadora desta doença (Auguste D.), Alois Alzheimer já descrevia que além das funções cognitivas 
prejudicadas, esta doença apresentava características anatômicas exclusivas: fibrilas diferentes das normais, desaparecimento das camadas do córtex, lesões com depósitos de uma substância cerebral e formações vasculares novas (Möller \& Graeber, 1998). As duas principais lesões anatômicas da Doença de Alzheimer são:

a) APP, 6-amilóide e placas senis

A proteína precursora do amilóide (APP) é responsável pela regulação do desenvolvimento celular e formação da proteína $\beta$-amilóide, que por sua vez está associada à formação de placas senis (figura 2).

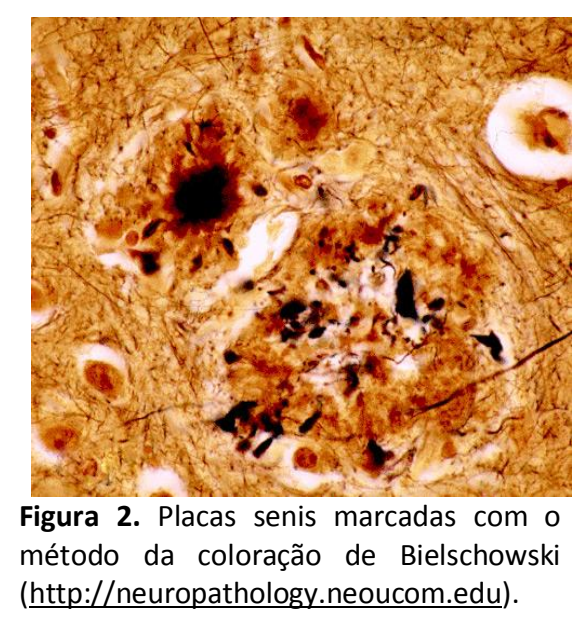

As placas senis são lesões encontradas no sistema nervoso central de pessoas portadoras da Doença de Alzheimer e são formadas por dendritos e axônios alterados, os quais são circundados pelo depósito extracelular de filamentos da proteína $\beta$-amilóide (Goldgaber et al, 1987; Maurer, Volk \& Gerbaldo, 1997; Aprahamian, Martinelli \& Yassuda, 2009).

A síntese da proteína precursora do amilóide ocorre no retículo endoplasmático e é glicosilada no complexo de Golgi. As enzimas responsáveis pela clivagem da APP são genericamente conhecidas como secretases, com isto, as terminações carboxila e amina são os produtos da clivagem pela $\beta$ - e $\gamma$ - secretase, respectivamente (Dawbarn \& Allen, 1995). 
Além de caracterizar a Doença de Alzheimer, a proteína $\beta$-amilóide também é produzida por um processo natural. Um estudo in vitro indicou que culturas de células cerebrais secretam a $\beta$-amilóide solúvel no plasma humano e no líquido cefalorraquidiano (Seubert et al., 1993). Outro estudo utilizou a técnica de imunoprecipitação e analisou este mesmo líquido retirado da autópsia de pacientes com Alzheimer e de controles; concluindo que a $\beta$-amilóide é secretada durante seu metabolismo normal (Shoji et al., 1992) e, portanto, esta proteína também é produzida por organismos sadios.

As placas senis não estão presentes apenas em humanos, Selkoe e colaboradores testaram anticorpos marcadores de placas neuríticas em humanos nos blocos do neocórtex de diferentes animais e, interessantemente, encontraram marcações nos seguintes animais: macaco rhesus (Macaca mulatta); orangotango (Pongo pgmaeus), macaco-de-cheiro (Saimiri sciureus); cachorro (Canis lupus familiaris) e urso polar (Ursus maitimus), todos com idades avançadas (Selkoe et al, 1987).

Aparentemente, no sistema nervoso central de pacientes com Alzheimer, a formação das placas senis possui a seguinte seqüência (Dawbarn \& Allen, 1995, p. 20):

1. Depósito da $\beta$-amilóide nas fendas sinápticas, degradação e perda da conectividade sináptica.

2. Lenta agregação da $\beta$-amilóide formando as fibrilas (as apolipoproteínas -ApoE- estão envolvidas neste processo).

3. Degeneração e regeneração dos neurônios associados com a ativação da microglia, fosforilação da proteína tau, distúrbios no metabolismo do cálcio e perda sináptica.

4. Condensação do amilóide, degeneração celular com o desarranjo do citoesqueleto e, finalmente, a formação das placas neuríticas.

\section{b) Proteína tau e emaranhados neurofibrilares}

A proteína tau é encontrada em todos os compartimentos do neurônio, possui seis isoformas e é encontrada em diferentes estados de fosforilação no sistema nervoso central. Sua função está associada ao arranjo estrutural dos neurônios, uma vez que sua projeção determina o espaço entre os microtúbulos, regulando o diâmetro axonal (Chen et al, 1992). 
Além disso, a tau também é responsável pelo equilíbrio entre a rigidez e a plasticidade nos processos neuronais (Matus, 1988).

$\mathrm{Na}$ Doença de Alzheimer, as proteínas ativadas por mitógenos (MAP) são responsáveis pela fosforilação anormal da proteína tau, que se agrega entre os filamentos neuronais, apresentando polímeros insolúveis. Esta lesão é conhecida como emaranhado neurofibrilar (figura 3) e junto com as placas senis fecha o diagnóstico da Doença de Alzheimer. Deste modo, a proteína tau patológica distingue-se da comumente encontrada no sistema nervoso central pelo seu estado de fosforilação (Grundke-lqbal, 1986 (a); Drewes et al, 1992; Buée et al, 2000).

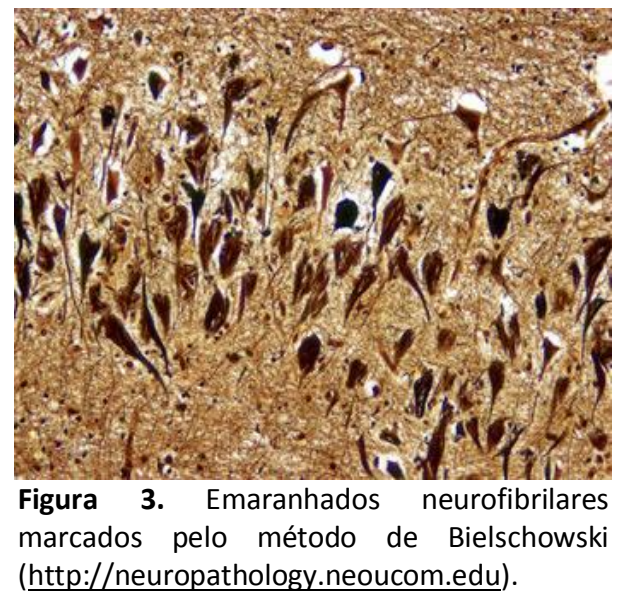

Lindwall e Cole acreditam que a patogenicidade da proteína tau teria um efeito significativo no tamanho e na extensão da polimerização dos microtúbulos, isto ocasionaria uma menor afinidade com os mesmos e esta desestabilização prejudicaria o transporte axonal dos neurônios (Lindwall \& Cole, 1984; Dawbarn \& Allen, 1995).

Na microscopia eletrônica os emaranhados apresentam-se como filamentos paralelos de feixes densos, de comprimentos indefinidos e que circundam o núcleo. Com uma alta definição, estes filamentos parecem formar uma dupla hélice (figura 4) (Kidd, 1963; Schweers et al, 1994; Arima, 2006). 


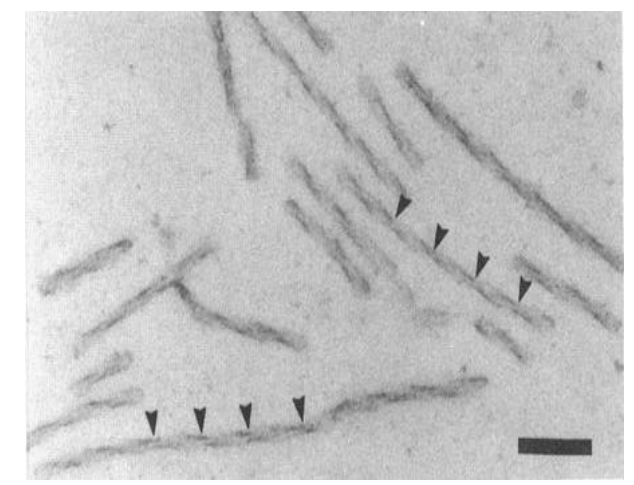

Figura 4. Micrografia eletrônica de marcação negativa dos filamentos helicoidais pareados do tecido de um paciente com Alzheimer. As pontas das setas indicam uma periodiocidade longitudinal (aproximadamente de 75 a 80 $\mathrm{nm}$ ) e a barra equivale a $100 \mathrm{~nm}$ (Schweers et al, 1994).

Esta aparência diferencia-se de qualquer outra fibrila normal do citoplasma e diversas proteínas participam da composição molecular desta dupla hélice (Grundke-Iqba et al (b), 1985; Goedert, 2006).

A distribuição dos emaranhados neurofibrilares é muito menor do que as placas senis ( $\beta$-amilóide), pois eles seguem um padrão neuroanatômico estereotipado com os seguintes estágios (Goedert, 2006):

Estágio 1: presença dos emaranhados no córtex entorrinal, na camada CA1 do hipocampo e no neocórtex, cujos locais são pouco mielinizados.

Estágio 2: maior ocorrência dos emaranhados neurofibrilares nas áreas entorrinal, transentorrinal, CA1 do hipocampo e no neocórtex (estágios do sistema límbico). Os fragmentos ficam gradativamente arredondados, difundindo-se em áreas neocorticais adjacentes e no hipocampo.

Estágio 3: os emaranhados são encontrados nas áreas mielinizadas, nas áreas de associação cortical e no córtex estriado.

Como conseqüência deste processo, os emaranhados neurofibrilares danificam as células piramidais, desconectando o hipocampo (Dawbarn \& Allen, 1995). 
Por fim, a proteína $\beta$-amilóide e a tau são fatores muito importantes na Doença de Alzheimer, pois o acúmulo anormal de ambas induz a fragmentação do DNA, indicando que a morte celular ocorre através do processo apoptótico (Loo et al, 1993; Fath et al, 2002).

\subsubsection{Fatores genéticos}

Citamos duas importantes lesões que são as principais características da Doença de Alzheimer, contudo, a etiologia da doença ainda é desconhecida, mas vários estudos demonstram que componentes genéticos estão associados a esta doença.

A característica genética do Alzheimer ou FAD (Familial Alzheimer Disease) pode apresentar no mínimo cinco genes defeituosos que causam a DA. As posições de três destes genes, FAD1, FAD2 e FAD3, são conhecidas e estão respectivamente nos cromossomos 21, 19 e 14. Com isso, pode-se explicar o motivo, no qual portadores da Síndrome da Down (conseqüência da trissomia do cromossomo 21) possuem uma maior predisposição em manifestar o Alzheimer (Goldgaber et al, 1987).

Outro fator ligado à doença é a apolipoproteína ApoE (Buée et al, 2000). ApoE é um componente da lipoproteína de densidade muito baixa que é sintetizada no fígado e sua função é transportar triglicérides deste órgão para os tecidos periféricos. Não obstante, a ApoE também pode ser um componente do complexo de lipoproteína de densidade alta e sua função está relacionada à redistribuição do colesterol nas células (Dawbarn \& Allen, 1995).

O gene responsável pela produção desta apolipoproteína é polimórfico e possui três isoformas: $\varepsilon 2$, $\varepsilon 3$ e $\varepsilon 4$ ApoE (Mahley, 1988). Notavelmente, quando encontrado em homozigose, o alelo $\varepsilon 4$ tem sido associado com o início do Alzheimer, mas, quando encontrado em heterozigose, esta associação não ocorre, a menos que haja uma interação com outros fatores, como o histórico familiar da doença (van Diuijn et al, 1994). 


\subsection{O sistema visual em pacientes com Alzheimer}

Diversas evidências suportam a idéia de que pacientes com Alzheimer possam apresentar déficits no sistema visual (Bayer et al, 2002; Mckinnon, 2003; Blancks et al, 2006 (a); Blancks et al, 2006 (b); Berisha et al, 2007).

Um fator importante que associa a Doença de Alzheimer com a visão é que as células ganglionares sintetizam a proteína precursora do amilóide (APP), a qual é transportada em vesículas pequenas para o nervo óptico em um processo rápido (Morin et al, 1993). Um estudo imunohistológico que utilizou anticorpos anti-tau, anti-APP e anti- $\beta$-amilóide em retinas de pessoas idosas sadias demonstrou que apenas a proteína $\beta$-amilóide é encontrada no epitélio pigmentar e está associada à idade (Löffler et al, 1995).

Outros estudos utilizaram portadores da doença para comprovar esta associação. Um exemplo é o estudo post-mortem de Blanks e colaboradores, que demonstrou uma diminuição das células ganglionares em pacientes com a Doença de Alzheimer nas seguintes regiões: fovéola (52\%); excentricidade de 0,5 a $1 \mathrm{~mm}$ (24\%) e de 1 a 1,5 mm (26\%) (Blanks et al, 1996 (a)). Este mesmo grupo demonstrou que portadores de Alzheimer apresentam um aumento na proporção astrócitos/neurônios de $87 \%$ na retina e a autopsia revelou que a perda das células ganglionares pode ser ocasionada pelo glaucoma ou por outra doença oftalmológica grave (Blanks et al, 1996 b).

Estudos in vivo também fazem esta associação; um deles comprovou que pacientes com Alzheimer apresentam uma diminuição do campo visual e/ou danos no disco óptico compatível com o glaucoma, porém, sem apresentar um aumento da pressão intraocular (Bayer et al, 2002). A Tomografia de Coerência Óptica (OCT) detectou um afinamento na camada de fibras nervosas da retina de pacientes com sintomatologia leve a moderada e, através do dopplerfluxométrico do olho, foram encontradas alterações no sistema circulatório da retina, semelhantes às encontradas no cérebro de portadores de Alzheimer (Berisha et al, 2007). 
Testes psicofísicos também detectaram déficits na visão de cores e na acuidade visual nos pacientes cuja doença apresentava-se moderada a grave (Pache et al, 2003).

Da mesma forma, diversos estudos utilizaram cobaias para comprovar as anomalias do sistema visual em pacientes com Alzheimer, inclusive a Drosofila tornou-se um modelo da doença. Em 2004, Greeve e colaboradores encontraram uma grave degeneração nos fotorreceptores, nas projeções axônicas e na neuropapila óptica, além disso, também foram observadas placas de amilóides na retina de Drosofilas transgênicas (Greeve et al, 2004).

Estudos morfológicos e eletrofisiológicos também usaram roedores para associar esta doença com disfunções no sistema visual e, no geral, os estudos apontaram que a proteína $\beta$-amilóide mostrou-se tóxica nos roedores modelos de Alzheimer, causando degenerações na retina de ratos (Jen et al, 1998) e em diferentes camundongos transgênicos:

- camundongo com os genes presenilina-1 (PS1) e APP mutantes inseridos: apresentou uma perda de células ganglionares e uma proliferação anormal das células da microglia (Ning et al, 2008);

- camundongo Tg2576: também apresentou uma perda de células ganglionares e uma proliferação anormal das células da microglia (Dutescu et al, 2009); e

- camundongo duplo-transgênico (APPswe/PS1deltaE9): apresentou alterações anatômicas e fisiológicas, pois, além da presença das placas senis nas camadas plexiformes internas e externas, ocorreu um aumento na atividade das células da microglia e a eletrorretinografia mostrou-se alterada, com uma redução das amplitudes das ondas - $a$ e - $b$ (Perez et $a l, 2009$ ).

\subsection{Camundongo}

Os camundongos (Mus musculus) são excelentes modelos biológicos, visto que podem ser manipulados em espaços pequenos, são fáceis de criar e não necessitam de uma dieta nutricional específica ou cara. Reproduzem-se durante o ano inteiro, possuem um 
curto tempo de gestação e, quando comparados com outros mamíferos, os camundongos geram uma grande quantidade de filhotes por ninhada (Hedrich et al, 2004).

As mais recentes vantagens da utilização destes animais estão ligadas à engenharia genética, pois, os camundongos são uma das únicas espécies que desenvolvem célulastroncos totipotentes in vitro, as quais são geneticamente manipuladas e, quando reintroduzidas no embrião, estes animais mantêm a capacidade de reproduzir uma nova linhagem (Hedrich, 2004).

Outra enorme descoberta digna de apreço foi o seqüenciamento completo do genoma do camundongo (Waterston et al, 2002), permitindo uma melhor compreensão da relação entre os genes e as doenças.

Assim, após centenas de estudos, o comportamento, a fisiologia e a genética dos camundongos tornaram-se bem compreendidos pelos cientistas e isto possibilitou com que vários camundongos fossem modificados geneticamente com o propósito de mimetizar as doenças humanas.

\subsubsection{A retina do camundongo}

\section{"Verdadeiro centro nervoso."}

(Ramon y Cajal, 1894 apud Granit, 1968)

A organização da retina de vertebrados é laminar, com camadas de diferentes tipos celulares intercaladas por camadas de conexões neurais (revisão em Ventura \& Hamassaki, 2005). A retina do camundongo (figura 6) possui as dez camadas conhecidas nas retinas dos vertebrados em geral: (1) epitélio pigmentado, (2) camada de fotorreceptores cones e bastonetes (segmentos externos e internos), (3) membrana limitante externa, (4) camada nuclear externa, com os núcleos dos fotorreceptores, (5) camada plexiforme externa, contendo as sinapses das células bipolares e horizontais com os fotorreceptores, (6) camada nuclear interna dos corpos celulares das células bipolares, horizontais e amácrinas, (7) camada plexiforme interna, contendo as conexões das células ganglionares com as células 
bipolares e amácrinas, (8) camada de células ganglionares, (9) camada de fibras nervosas, contendo os axônios das células ganglionares, passando para o nervo óptico, (10) membrana limitante externa (figura 5).

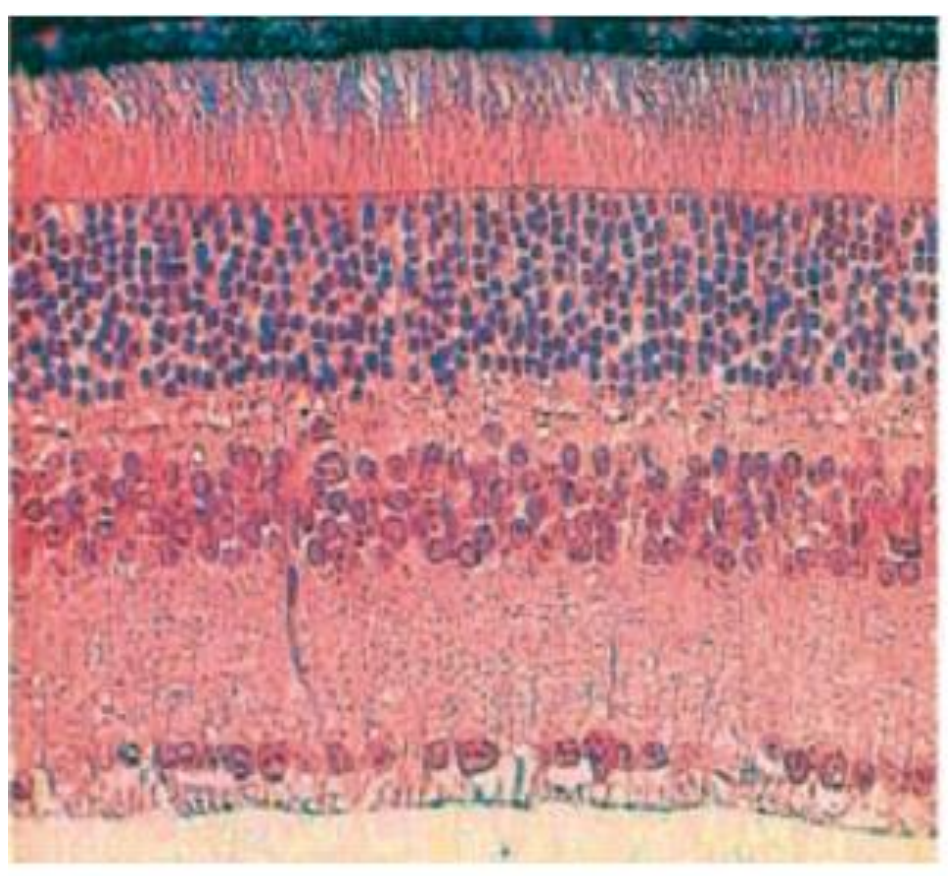

Figura 5. Corte radial da retina de um camundongo com 6 meses de idade corado com Hematoxilina-Eosina, mostrando disposição de todas as camadas celulares e intercelulares. (Amplificação: x800) (Numeração equivalente à figura 1) (Cuthbertson \& Mandel, 1986).

Dentro do padrão de organização anatômica presente em diferentes vertebrados, as características de cada camada, como o arranjo e a densidade celular, podem variar de espécie para espécie.

Em 1998, Jeon e colegas descreveram quantitativamente as células da retina do camundongo C57/B6 (uma das linhagens mais comuns utilizadas em pesquisas) e encontraram a densidade média dos cones: 12.400 células $/ \mathrm{mm}^{2}$; a densidade média dos bastonetes: 437.000 células $/ \mathrm{mm}^{2}$ (representando $97 \%$ do total dos fotorreceptores) e na camada nuclear interna encontraram: $41 \%$ de células bipolares, 39\% de amácrinas, 16\% de células de Müller e 3\% de células horizontais (Figura 6) (Jeon et al, 1998). 


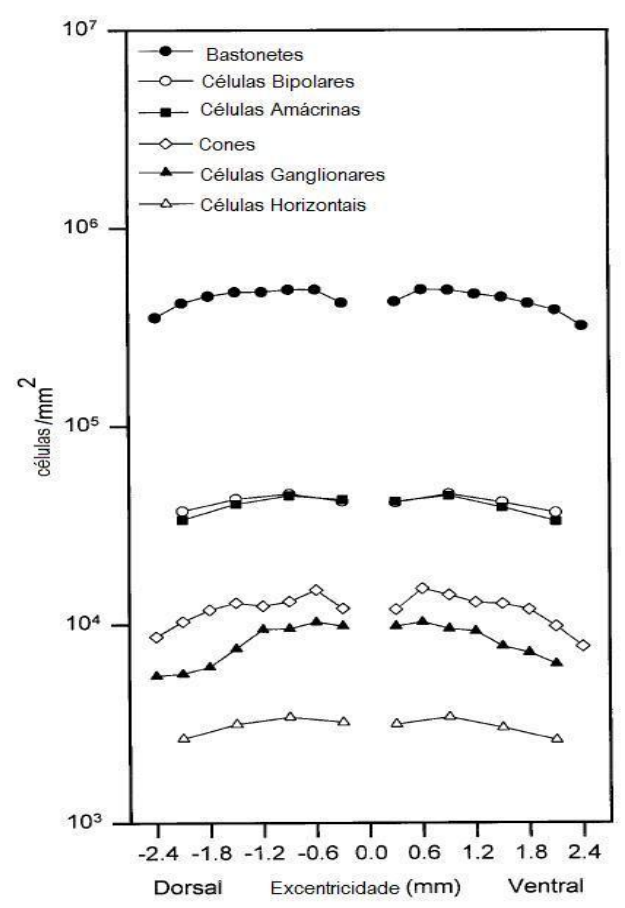

Figura 6. Distribuições comparativas das maiores classes de células na retina do camundongo. Todos os dados são da colônia americana do camundongo C57BL6 (Jeon et al 1998).

Assim como qualquer mamífero não primata, os camundongos apresentam apenas duas classes de cones, caracterizando seu sistema visual como dicromata (Jacobs \& Howe, 2004). Na figura 7, podemos observar que os fotorreceptores dos camundongos estão organizados em um mosaico sistematicamente regular (Jeon et al, 1998; Fei, 2003).

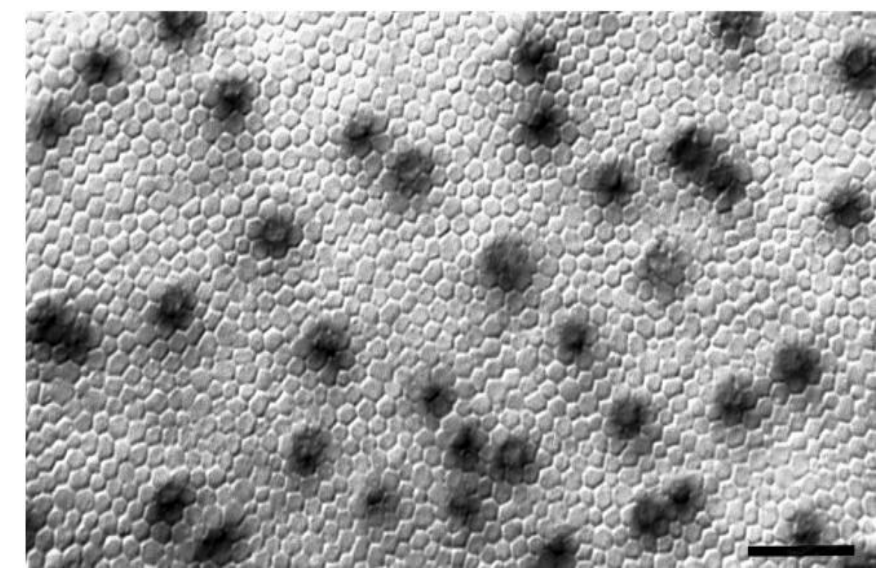

Figura 7. Mosaico de cones e bastonetes da retina de camundongo. Plano focal através dos segmentos internos dos fotorreceptores. As estruturas poligonais mais claras são os segmentos internos dos bastonetes e as estruturas escuras são os segmentos internos dos cones (reação com diaminobenzidina). Barra $=10 \mu \mathrm{m}$ (Jeon et al, 1998). 
Outra característica da retina do camundongo é a variabilidade da densidade das células horizontais encontrada em diferentes linhagens. Williams e colaboradores, através da marcação positiva à calbindina- $\mathrm{D}_{28 \mathrm{k}}$, marcaram a população de células bipolares de seis linhagens diferentes de camundongos e encontraram diferenças significativas nas densidades. A figura 8 compara as células horizontais marcadas entre as duas linhagens que tiveram maior diferença de densidade: C57/B6 e A/j (Williams et al, 1998).

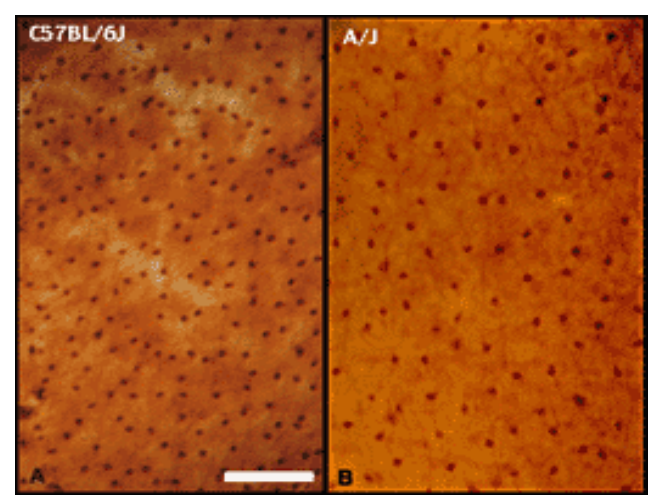

Figura 8. Micrografias das células horizontais marcadas com calbindina de duas linhagens de camundongo. Densidades: C57/B6 1151/mm² (17.5) e A/J 561 (8.09). Barra: $100 \mu \mathrm{m}$ (Williams et al, 1998).

No camundongo, há nove tipos morfológicos diferentes de células bipolares de cones e um tipo de célula bipolar de bastonete classificados com base no padrão das ramificações e no nível da estratificação das terminações dos axônios na camada plexiforme interna, segundo marcações com Neurobiotina e Lucifer yellow (figura 9). Estas células bipolares do camundongo segregam os sinais de luz e constituem a base do processamento paralelo da informação visual (Ghosh et al, 2004).

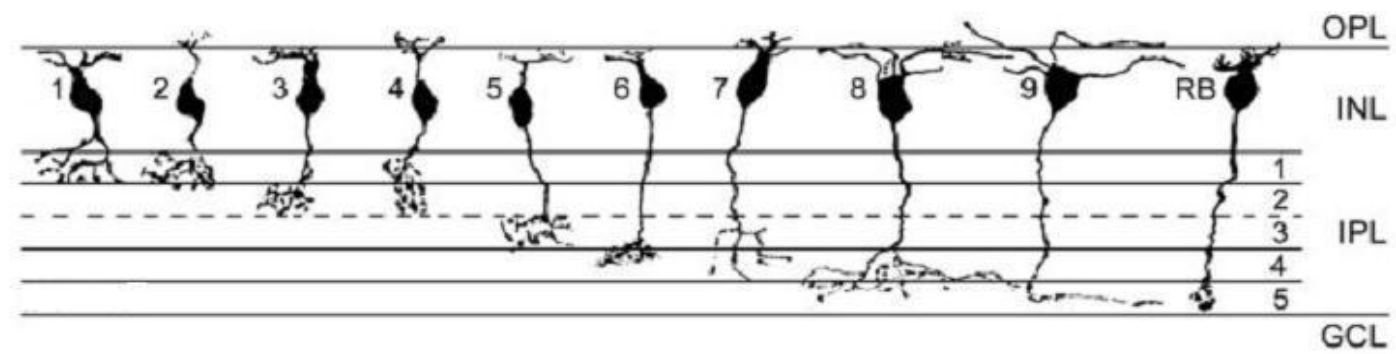

Figura 9. Diagrama das células bipolares encontradas no camundongo: nove são de cones $(1-9)$ e uma é de bastonetes (RB) (Ghosh et al, 2004). 
As células amácrinas são interneurônios que modulam a transferência dos sinais de luz através da retina. No camundongo, as amácrinas que possuem campo pequeno e médio contêm dendritos difusos na camada plexiforme interna, que podem fazer conexões em diversos estratos. Lin e Masland encontraram vários subtipos de amácrinas que possuem campo grande (figura 10), neste caso, as células são responsáveis em mediar as interações laterais (Lin \& Masland, 2006).

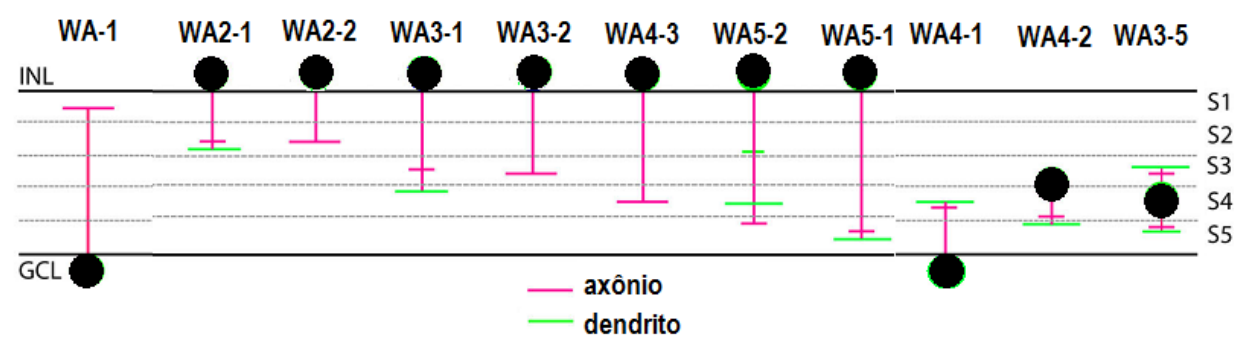

Figura 10. Diagrama das células amácrinas de campo grande encontradas por Lin e Masland. Os nomes correspondentes estão escritos acima das células. Os processos verdes representam a profundidade dos dendritos e os rosas, dos axônios. S1 - S4 são os estratos (Lin \& Masland, 2006).

A distribuição das células ganglionares dos camundongos apresenta maior densidade ao redor do nervo óptico (Dräger e Olsen, 1981; figura 11A) e as populações de ganglionares deslocadas são encontradas na camada nuclear ( $2 \%$ do total das células ganglionares) (figura 11B) (Drädger \& Olsen, 1981).
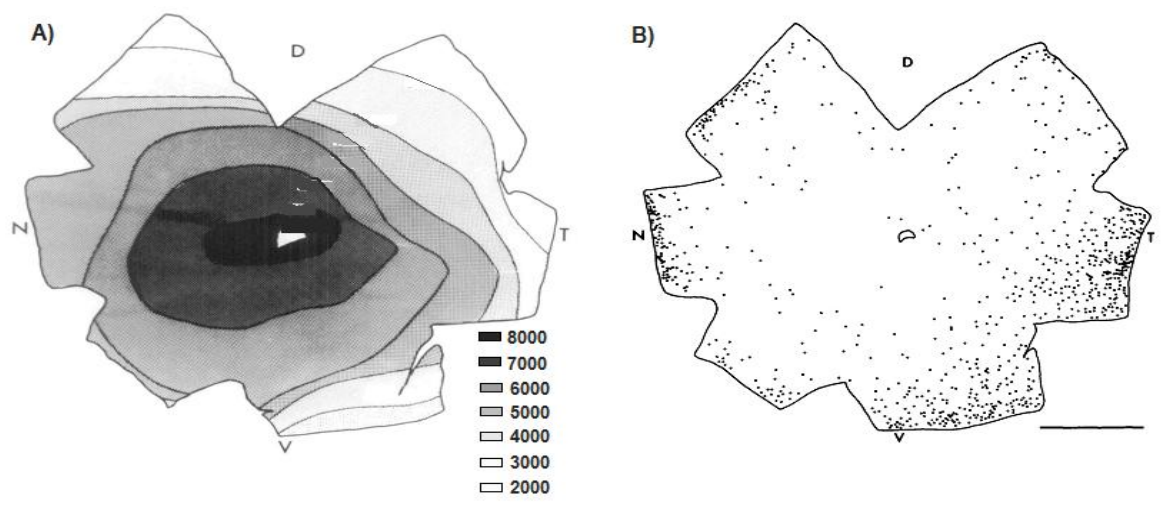

Figura 11. Contornos da retina de camundongo. A) Sumário da isodensidade padrão das células ganglionares marcadas com a técnica de Nissl. B) Cada ponto indica uma célula ganglionar deslocada que foi corada com peroxidase de raiz forte $(D=$ dorsal, $V=$ ventral, $N=$ nasal, $\mathrm{T}=$ temporal e barra $=1 \mathrm{~mm}$ ) (Drädger \& Olsen, 1981). 
Parâmetros morfométricos, como o formato, tamanho do corpo celular, diâmetro, morfologia e estratificação do dendrito, aplicados em células injetadas com Neurobiotina permitiram a identificação de 22 subtipos de ganglionares nos camundongos C57/B6; figura 12 (Volgyi et al., 2009).

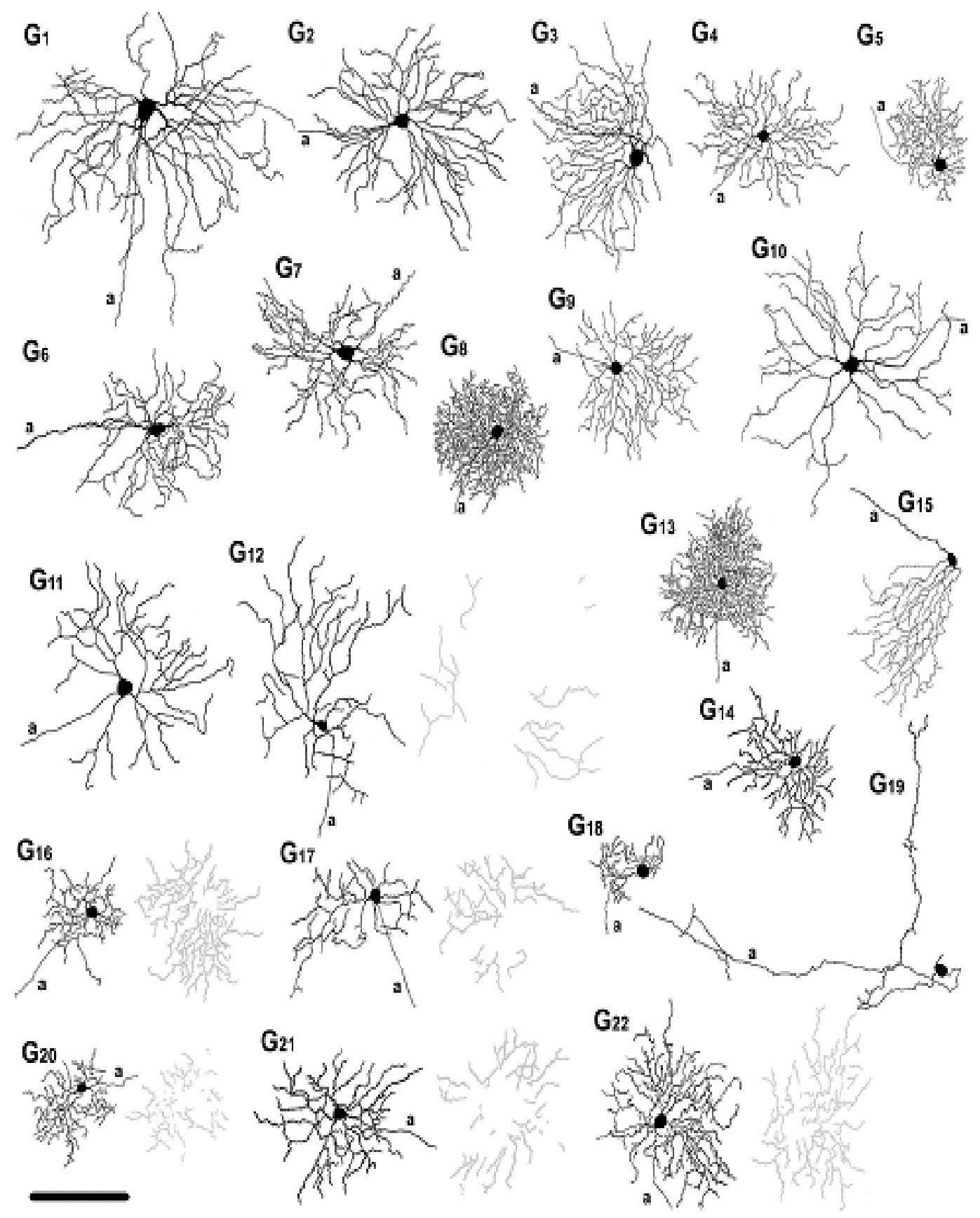

Figura 12. Diagrama dos 22 subtipos de células ganglionares (G1 - G22). As células ganglionares biestratificadas, cujos dendritos são proximais estão desenhadas em preto e os distais, em cinza (Barra = 100 $\mu \mathrm{m}$ ) (Volgyi et al, 2009). 


\subsubsection{Camundongo triplo-transgênico (3xTg-AD)}

O camundongo triplo-transgênico (3xTg-AD) foi desenvolvido por Frank M. LaFerla da Universidade da Califórnia. Este modelo distingue-se dos outros por desenvolver as duas lesões histopatológicas que caracterizam a Doença de Alzheimer em regiões relevantes do cérebro, como a amígdala, o hipocampo e o córtex (LaFerla \& Oddo, 2005).

Ao invés de cruzar três linhagens independentes, os pesquisadores derivaram o $3 \times \mathrm{Tg}$ $A D$ da introdução direta de 2 transgenes mutantes adicionais - transgene é o material genético que foi transferido de um animal para outro através da engenharia genética (Watson et al, 2006)- $\mathrm{APP}_{S W E} \mathrm{e}$ tau $\mathrm{P}_{301 \mathrm{~L}}$, no embrião de camundongos geneticamente modificados (homozigotos PS1M146V knock-in) (figura 13). Estes transgenes foram inseridos no mesmo loco genético, possibilitando que futuras gerações desenvolvessem os dois genes de forma dependente, além disso, a inserção destes genes ao embrião do camundongo homozigoto PS1 (Guo et al, 1999) foi realizada de modo que a reprodução destes animais triplo-transgênicos fosse semelhante a qualquer camundongo transgênico simples (Oddo et $a l, 2003)$.

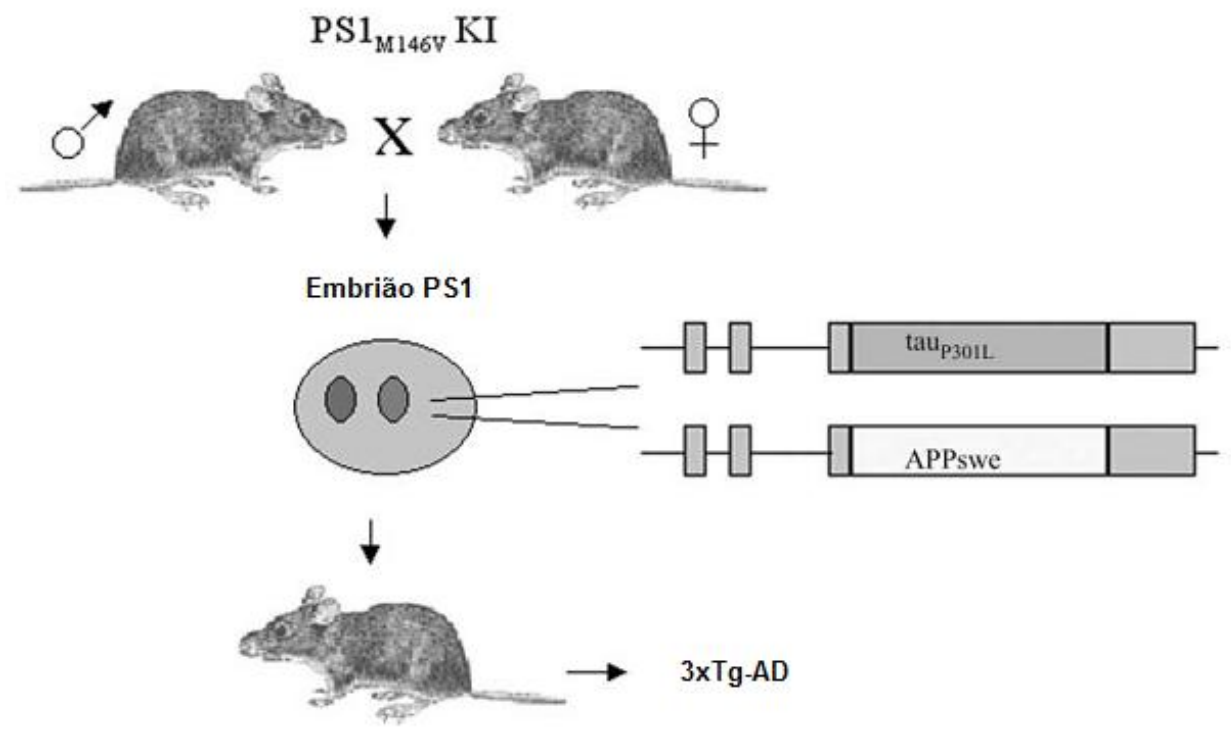

Figura 13. Estratégia utilizada no desenvolvimento do camundongo 3xTg-AD. Foram coinjetados dois transgenes, $\mathrm{APP}_{\mathrm{SWE}_{\mathrm{E}}}$ e tau ${ }_{\mathrm{P} 301 \mathrm{~L}}$, no embrião do camundongo transgênico PS1, o cruzamento desta nova linhagem de camundongos originou o camundongo modelo de Alzheimer, 3xTg-AD (Oddo et al, 2003). 
É importante ressaltar que a linhagem primordial do nosso modelo experimental já é transgênica (camundongo PS1 $1_{\mathrm{M} 146 \mathrm{~V}}$ ) e, portanto, o grupo controle dos camundongos $3 \times \mathrm{xTg}$ $\underline{A D}$ também é transgênico, possuindo apenas o gene PS1 humano não mutante.

Justamente por serem transgênicos, estudos com estes controles foram realizados para descartarem qualquer tipo de alteração fenotípica neste animal e, até agora, não há evidências de alterações funcionais fisiológicas da presenilina humana presente nos camundongos PS1 $1_{\mathrm{M} 146 \mathrm{~V}}$ (Shen et al, 1997; Qian et al, 1998; Guo et al, 1999).

Por outro lado, o camundongo 3xTg-AD apresentou um acúmulo da proteína $\beta$ amilóide que precede a formação dos emaranhados neurofibrilares. Este fato está de acordo com a hipótese do amilóide, a qual, através de estudos genéticos, moleculares, bioquímicos e neuropatológicos, prediz que o acúmulo desta proteína possui um papel central, iniciando a cascata patogênica da Doença de Alzheimer. Aparentemente o processo patológico, incluindo o desenvolvimento dos emaranhados neurofibrilares, é uma conseqüência do desequilíbrio entre a síntese e a desnaturação desta proteína (Hardy \& Selkoe, 2002; Rohn et al, 2008).

A $\beta$-amilóide é encontrada no neocórtex dos camundongos 3xTg-AD entre três e quatro meses de idade; ao atingirem seis meses, os animais apresentam um acúmulo da proteína no hipocampo, disfunções sinápticas e déficit da potenciação de longa duração (LTP). Já os emaranhados neurofibrilares aparecem nestes animais a partir dos dezoito meses de idade (Oddo et al, 2003).

\subsection{O eletrorretinograma}

O eletrorretinograma (ERG) é um registro elétrico do olho em resposta a um estímulo luminoso. Esta resposta é obtida por meio do registro da diferença de potencial entre um eletrodo posicionado na córnea e um eletrodo de referência. Alguns componentes da onda são analisados através das medições das amplitudes e latências, as quais são respostas de neurônios, células da glia e células do epitélio pigmentar (figura 14). 

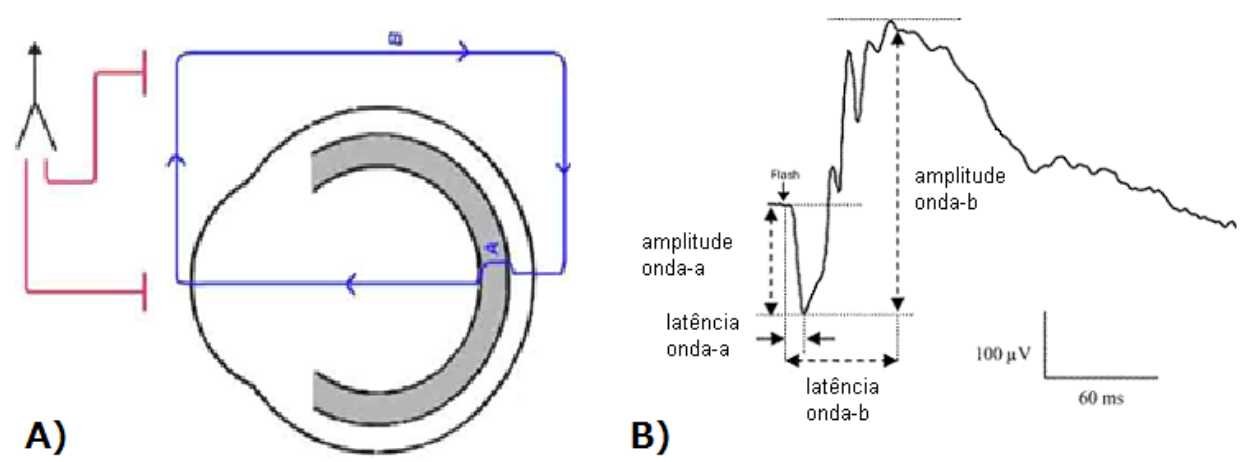

Figura 14. A) Representação das correntes extracelulares formadas quando ocorre uma estimulação luminosa. A trajetória $A$ representa a corrente local dentro da retina. A trajetória $B$ mostra as correntes que saem da retina através do vítreo e da córnea e retornam à retina através da coróide e do epitélio pigmentar. O registro do eletrorretinograma se dá pela trajetória $B$ (fonte: webvision.med.utah.edu). B) Resposta escotópica máxima do camundongo C57/B6 e marcações das amplitudes e latências das ondas $-a$ e $-b$ (resposta registrada do camundongo controle b6;129 em nosso laboratório).

A figura 14 mostra duas ondas muito estudadas: onda- $a$ e onda- $b$. A primeira referese à hiperpolarização dos fotorreceptores e a onda-b, à despolarização das células de Müller ocasionada pelo aumento da concentração de potássio na retina interna e pela ativação das células bipolares on (Wachtmeister, 1998).

Para facilitar a comparação da eletrorretinografia em diferentes laboratórios e clínicas, a Sociedade Internacional de Eletrofisiologia Clínica da Visão (ISCEV) padronizou um protocolo básico que visa avaliar as seguintes respostas (Marmor et al, 2008):

- escotópica de bastonetes,

- escotópica máxima,

- escotópica de potenciais oscilatórios,

- fotópica de cones ao flash único e

- fotópica de flicker.

Os laboratórios que realizam ERGs em animais também baseiam-se neste mesmo protocolo. 


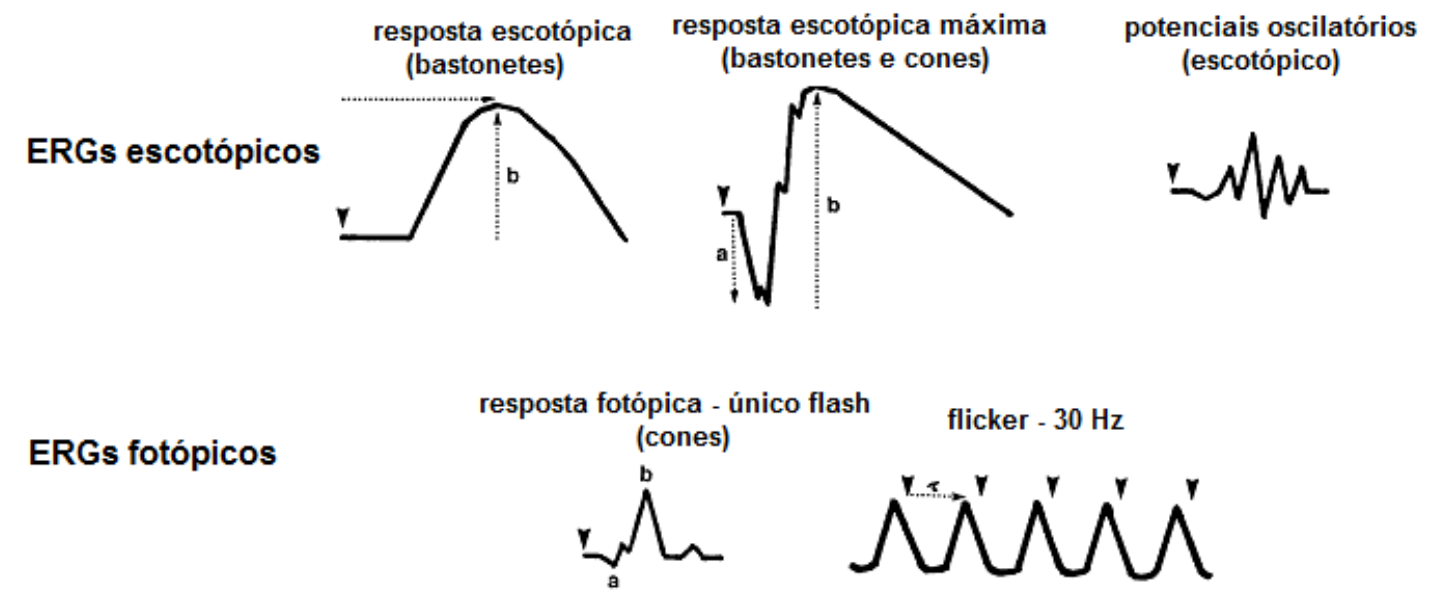

Figura 15. Diagrama do esboço das principais respostas de ERGs baseadas no protocolo da ISCEV. As cabeças das setas indicam o momento do estímulo (flash) (Marmor et al, 2008).

Utilizando o eletrorretinograma, estudos realizados pelo nosso laboratório correlacionaram as disfunções eletrofisiológicas da retina com algumas doenças:

1) Intoxicação mercurial

Trabalhadores de indústrias de lâmpadas fluorescentes aposentados por motivo de intoxicação mercurial resultante de exposição ao vapor de mercúrio apresentaram várias alterações no ERG de campo total comparados com controles: redução da amplitude da onda b escotópica máxima, da soma de potenciais oscilatórios, da resposta ao flicker de $30 \mathrm{~Hz}$ e da resposta adaptada à luz de cones. Também no ERG multifocal foram encontradas reduções da amplitude da resposta e aumento da latência, mostrando comprometimento da retina central (Ventura et al., 2004) . Estes achados revelaram pela primeira vez que há comprometimento da retina na intoxicação mercurial.

\section{2) Diabetes tipo 2}

Foram encontrados alguns componentes alterados do ERG de campo total em pacientes diabéticos do tipo 2 com fundo de olho normal: diminuição da amplitude da onda- $b$, diminuição dos potenciais oscilatórios e aumento das latências (Gualtieri, 2004). Reduções de amplitude e aumento de latência também foram encontradas no ERG multifocal (Gualtieri, 2009).

3) Distrofia Muscular de Duchenne 
Confirmando estudos anteriores, foram encontradas alterações nos ERGs de sujeitos com Distrofia Muscular de Duchenne como: redução da amplitude e aumento da latência da onda- $b$; ERG negativo (razão das amplitudes entre as ondas - $b$ e - $a$ menor que 1) e redução significativa no $3^{\circ}$ e no $4^{\circ}$ potenciais oscilatórios (Costa, 2004).

\section{4) Glaucoma}

Utilizando estímulos heterocromáticos com modulação de LEDs vermelho e verde em contra fase no eletrorretinograma de campo total, Barboni e colaboradores encontraram mudança de fase nas respostas dos canais visuais de luminância e de oponência cromática no componente fundamental e no segundo harmônico em pacientes com glaucoma (Barboni et al, 2010).

Além dos estudos em humanos, através do ERG em animais, nosso laboratório demonstrou a ausência da curva de sensibilidade espectral do cone $M$ em camundongos com mutação no receptor do hormônio tireóideo (gene (TR)- $\beta$ ) em resposta a flashes de diferentes comprimentos de onda, cuja expressão imunohistoquímica esteve também ausente nos mesmos animais (Pessôa et al, 2008)

Assim, estes exemplos ilustram a importância do eletrorretinograma como uma ferramenta que avalia a eletrofisiologia da retina, muitas vezes, diagnosticando algumas doenças retinianas e detectando alterações visuais antes da ocorrência de alterações fundoscópicas (Pereira et al, 2003). 


\section{JUSTIFICATIVAS}

A literatura prévia indica que algumas funções e estruturas do sistema visual podem estar prejudicadas nos pacientes com Alzheimer, por exemplo: diminuição das fibras do nervo óptico, opacidade do cristalino, perdas funcionais na via magnocelular, diminuição da sensibilidade ao contraste e do processamento temporal (Pache et al, 2003; Valenti, 2010). Constatou-se também que estes portadores possuem uma maior probabilidade de desenvolver lesões no nervo óptico semelhantes àquelas ocorrentes no glaucoma (Blanks et al, 1996 a; Blanks et al, 1996 b; Bayer et al, 2002).

Além dos aspectos funcionais, estudos morfológicos demonstraram que a $\beta$-amilóde, a tau e as placas senis podem ser encontradas na retina (Morin et al, 1993; Greeve et al, 2004; Ning et al, 2008; Dutescu et al, 2009; Perez et al, 2009). Esta relação entre o Alzheimer e a visão pode ser estudada em modelos animais com a finalidade de se preparar um modelo para analisar longitudinalmente os efeitos de drogas neuroprotetoras e aprofundar os conhecimentos da etiologia da doença.

Apesar de o camundongo 3xTg-AD ser um transgênico considerado o modelo mais completo da Doença de Alzheimer por produzir tanto a proteína humana tau quanto a $\beta$ amilóde (Carroll et al, 2007; Rohn; Gautheron et al, 2009; Blurton-Jones et al, 2009), inexistem estudos sobre alterações visuais neste camundongo e para detectar estas alterações visuais associadas à Doença de Alzheimer, em específico, as disfunções retinianas, o eletrorretinograma seria um equipamento muito eficiente.

Assim, baseando-se nos estudos citados acima e admitindo que as disfunções eletrofisiológicas e morfológicas da retina em pacientes com Alzheimer sejam semelhantes àquelas encontradas em pacientes glaucomatosos, nosso objetivo ulterior será comparar os resultados aqui obtidos com os que estão sendo encontrados pelo grupo de Jan Kremers, cujo trabalho analisou a eletrofisiologia e a morfologia da retina do modelo biológico de glaucoma (Mus musculus DBA/2J) (Harazny et al, 2009). 


\section{OBJETIVO}

O objetivo deste trabalho é estudar as possíveis repercussões funcionais da retina na Doença de Alzheimer em um modelo animal in vivo, utilizando respostas eletrofisiológicas não invasivas.

Objetivos específicos:

Através do eletrorretinograma de campo total, analisar e caracterizar a função retiniana do camundongo modelo de Alzheimer (Mus musculus 3xTg-AD) e seu controle (linhagem B6;129) ao longo de 5 idades $(2,4,6,8,10$ e 12 meses), medindo as seguintes funções,:

1. Função escotópica de luminância.

2. Função fotópica de processamento temporal de luminância.

3. Resposta de bastonetes.

4. Resposta de cones. 


\section{MÉTODO}

\subsection{Sujeitos}

A partir da importação de 4 casais de camundongos Mus musculus (3xTg-AD) e de seu controle $(B 6 ; 129)$ (Charles River) foi constituída uma colônia desses animais na Faculdade de Medicina Veterinária e Zootecnia da Universidade de São Paulo sob responsabilidade da Profa. Dra. Maria Lucia Zaidan Dagli. O estudo recebeu autorização da CTNBio (1438-2008) por envolver animais transgênicos e foi realizado sob supervisão da CIBio da unidade, com CQB número 100/99. O projeto recebeu também aprovação do Comitê de Ética em Pesquisa Animal (CEPA) do Instituto de Psicologia da USP.

Após o desmame, os camundongos ficaram alojados em uma estante ventilada no biotério do Instituto de Psicologia para a realização dos experimentos. Foram mantidos grupos de cinco animais por gaiola de poliestireno apropriada com ração e água ad libitum,

Foram realizados os eletrorretinogramas nos seguintes animais:

- 23 camundongos controles (PS1) da linhagem B6;129,

- 44 camundongos transgênicos 3xTg-AD e

- 9 camundongos controles C57/B6* .

* Como o grupo controle b6;129- PS1 apresentou respostas divergentes que serão descritas nos resultados, foi necessária a inclusão de um outro grupo controle -camundongos da linhagem C57/B6 (não transgênico)- o qual se tornou referencial.

A genotipagem de todos os camundongos utilizados foi realizada no Centro de Pesquisa Experimental do Instituto Israelita de Ensino e Pesquisa do Hospital Israelita Albert Einstein por Daniela Bonci e Camila do Carmo Gogoni.

Antes da realização dos ERGs, todos os camundongos foram adaptados ao escuro, no mínimo, durante 18 horas na sala de experimentação. Os ERGs foram registrados nos camundongos sucessivamente aos 2, 4, 6, 8, 10 e 12 meses de idade, em procedimento longitudinal. 


\subsection{Eletrorretinograma}

Para a realização dos ERGs, os animais eram anestesiados através da injeção intraperitoneal da solução de hidrocloreto de cetamina, hidrocloreto de xilazina e soro fisiológico $(1: 1: 10$, sendo $100 \mathrm{ml} / \mathrm{kg})$, as pupilas eram dilatadas com fenilefrina e três eletrodos eram posicionados no animal:

- um eletrodo de lente de contato sobre a córnea (Mayo Corporation, Japão) (Figura 16B),

- um eletrodo agulha de referência na cabeça e

- um terra na cauda (Figura 16C).

Para o registro eletrofisiológico, os animais eram devidamente posicionados dentro de uma gaiola de Faraday $(60 \mathrm{~cm} \times 60 \mathrm{~cm})$ sobre um refratário com água morna para manter a temperatura do animal. Os pulsos de luz eram gerados por um estimulador GRASS (PS33 Plus) e apresentados em um Ganzfeld (LKC 2503B) situado dentro da gaiola de Faraday (Figura 16A). A resposta elétrica obtida passava por um amplificador e era digitalizada (interface National Instruments) para ser analisada com o programa de aquisição de dados (Labview) gentilmente cedido ao laboratório por Steve Nusinowitz e John Ramirez.
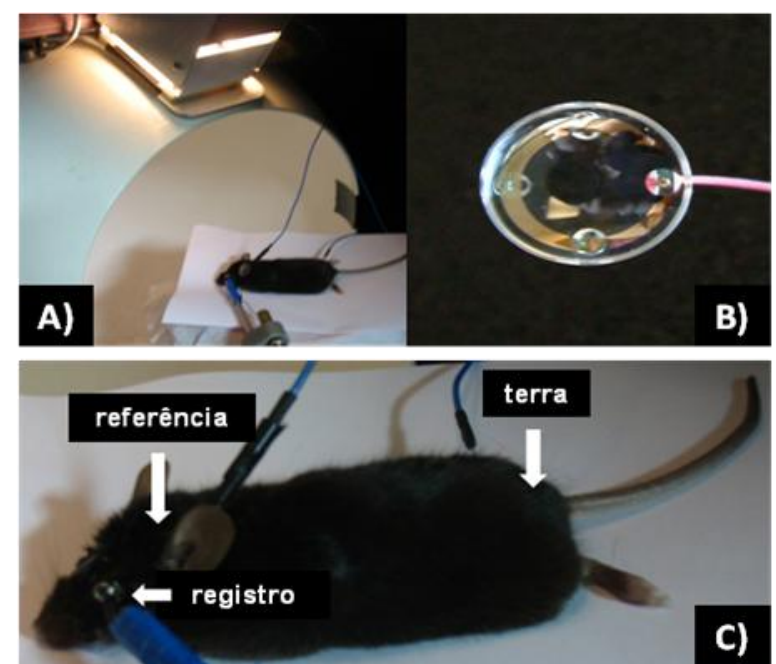

Figura 16. A) Camundongo C57/B6 anestesiado dentro do Ganzfeld com a luz de fundo. B) Eletrodo de registro do tipo lente (Mayo corporation), diâmetro da lente $=3 \mathrm{~mm}$. C) Camundongo com os eletrodos terra e referência do tipo agulha e eletrodo de registro do tipo lente sobre a córnea. 


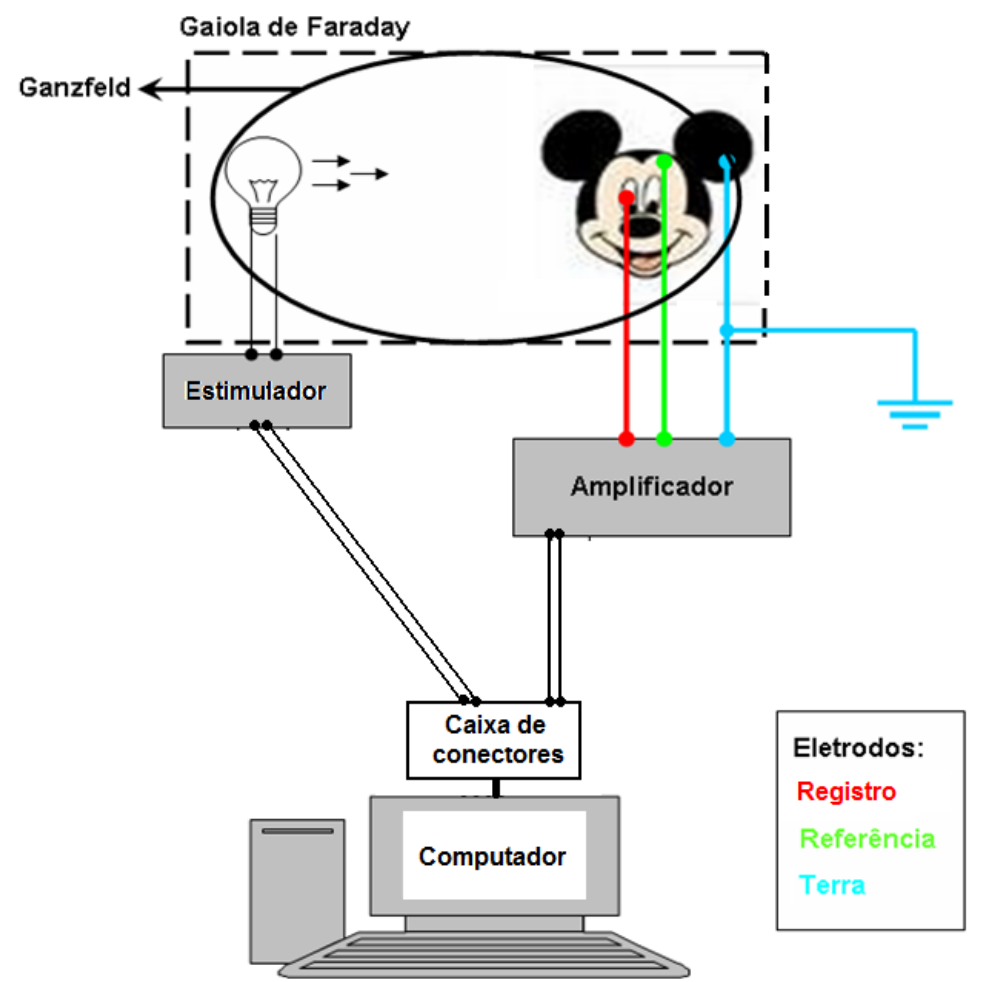

Figura 17. Esquema do eletrorretinograma utilizado neste trabalho.

Em sessão de 30 a 40 minutos de duração, o experimento era baseado no protocolo padrão da ISCEV, ampliado por Jan Kremers (Harazny et al, 2009):

1) Resposta escotópica - com o animal adaptado ao escuro, foram emitidos 10 flashes em cinco intensidades: $\underline{0,003} ; \underline{0,03} ; \underline{0,3} ; \underline{3}$ e $\underline{30} \mathrm{~cd} . \mathrm{s} / \mathrm{m}^{2}$. Os intervalos inter-flashes foram de 5,8 , 10,13 e 15 segundos, respectivamente;

2) Resposta de cones - com o animal adaptado à luz $\left(30 \mathrm{~cd} / \mathrm{m}^{2}\right)$ durante 2 minutos, foram emitidos 10 flashes $\left(30 \mathrm{~cd} / \mathrm{m}^{2}\right)$ com intervalo inter-flash de 5 segundos sob uma luz de fundo de $30 \mathrm{~cd} / \mathrm{m}^{2}$;

2) Resposta de flicker - foram emitidos 50 flashes $\left(30 \mathrm{~cd} . \mathrm{s} / \mathrm{m}^{2}\right.$ ) em 12,18 e $30 \mathrm{~Hz}$ sob uma luz de fundo de $30 \mathrm{~cd} / \mathrm{m}^{2}$. 
Para a análise estatística comparamos os diferentes grupos (variáveis independentes) e também animais do mesmo grupo ao longo do tempo (variáveis dependentes).

Para as comparações entre os diferentes grupos cujos dados apresentassem distribuição normal, o teste ANOVA foi utilizado. Não sendo compravada normalidade, foi utilizado o teste Kruskal-Wallis. Tukey foi o teste post hoc utilizado. Para as comparações dentro do mesmo grupo, ao longo do tempo, foi utilizado o teste de Wilcoxon.

Todos os testes estatísticos foram realizados apenas para os grupos com mais de três dados.

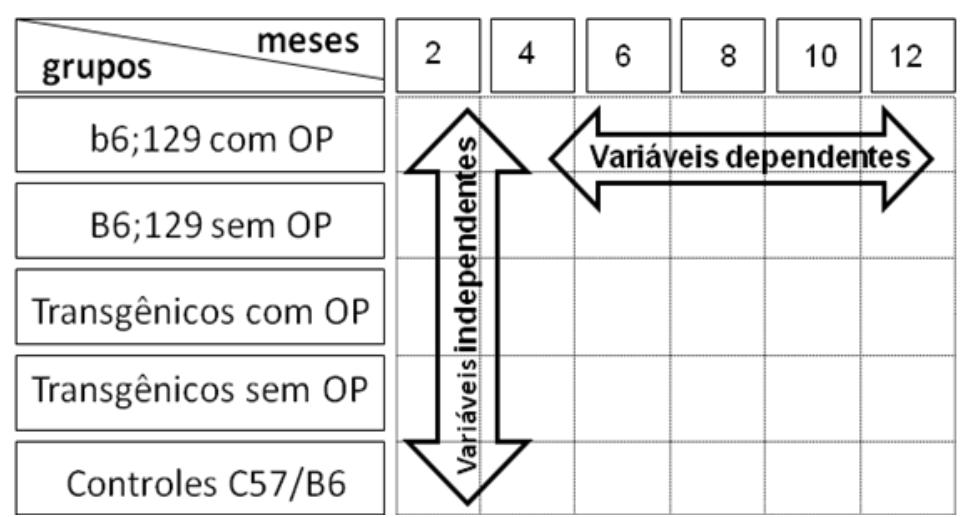

Figura 24. Variáveis dependentes e independentes presentes em nosso estudo. 


\section{RESULTADOS}

Diferentemente do esperado, ao serem expostos a estímulos escotópicos, tanto o grupo controle (b6;129-PS1) quanto o grupo modelos de Alzheimer (3xTg-AD) apresentaram dois tipos de respostas eletrorretinográficas (Figura 18):

\section{Resposta com potenciais oscilatórios}

Resposta cujas características assemelham-se àquelas encontradas no grupo dos camundongos C57/B6 e em relatos prévios de outros camundongos controles (Bayer et al, 2001; Fu et al, 2005; Harazny et al, 2009) (figura 20).

\section{$>$ Resposta sem potenciais oscilatórios}

Resposta cuja onda- $b$ apresenta-se muito mais lenta e geralmente de menor amplitude quando comparada à resposta anterior. Além disso, não possui potenciais oscilatórios.
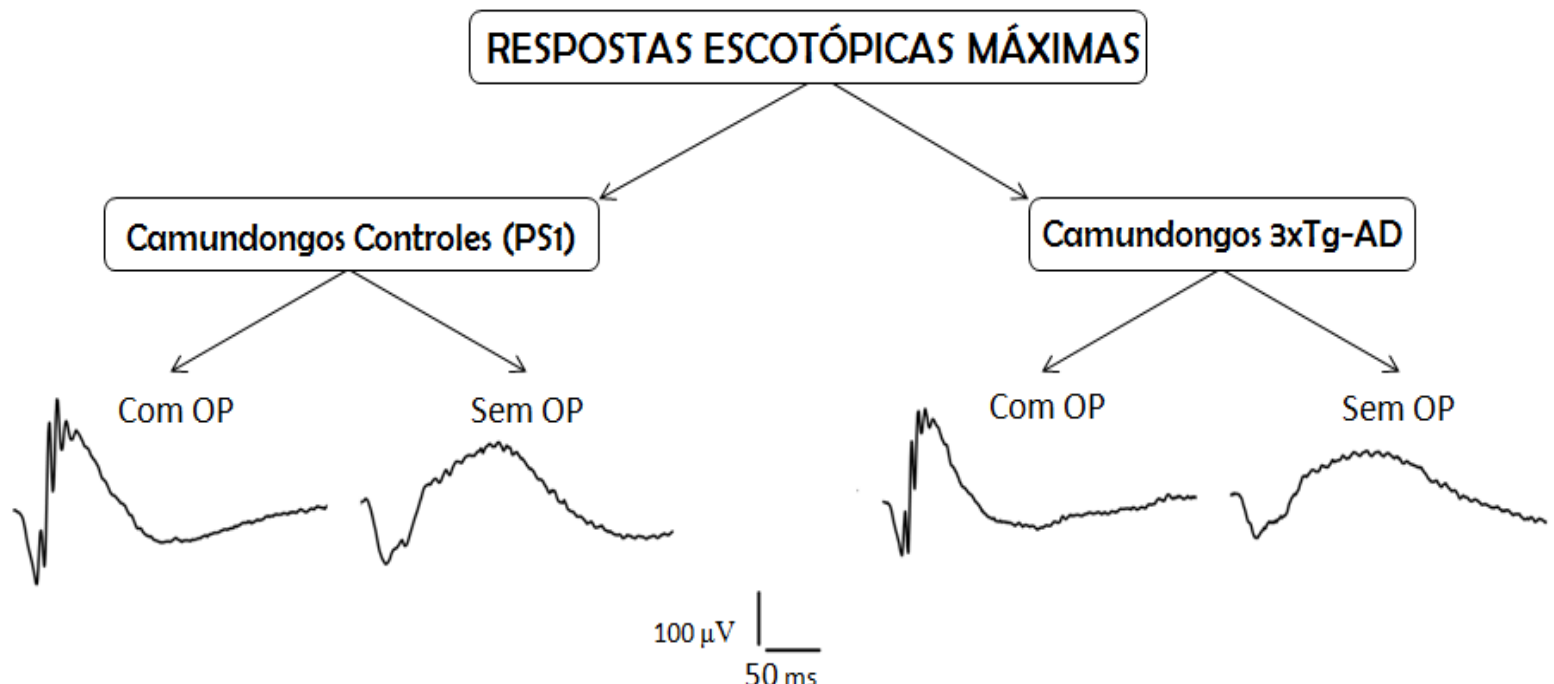

Figura 18. Diagrama das respostas escotópicas máximas registradas nos camundongos controles (PS1) e modelos de Alzheimer (3xTg-AD). Nota-se que ambos os grupos apresentam dois tipos de ondas cujos componentes são totalmente diferentes: OP presentes e OP ausentes; este último grupo também possui uma latência maior quando comparado ao grupo que contém os potenciais oscilatórios.

Para visualizarmos melhor os potenciais oscilatórios, filtramos as respostas escotópicas máximas através do programa MATLAB (passa banda 100-300 Hz) e eliminamos 
os componentes lentos destas ondas. Na figura seguinte, podemos observar claramente a presença destes potenciais em alguns animais e sua ausência em outros.

Respostas escotópicas máximas filtradas entre 100 e $300 \mathrm{~Hz}$

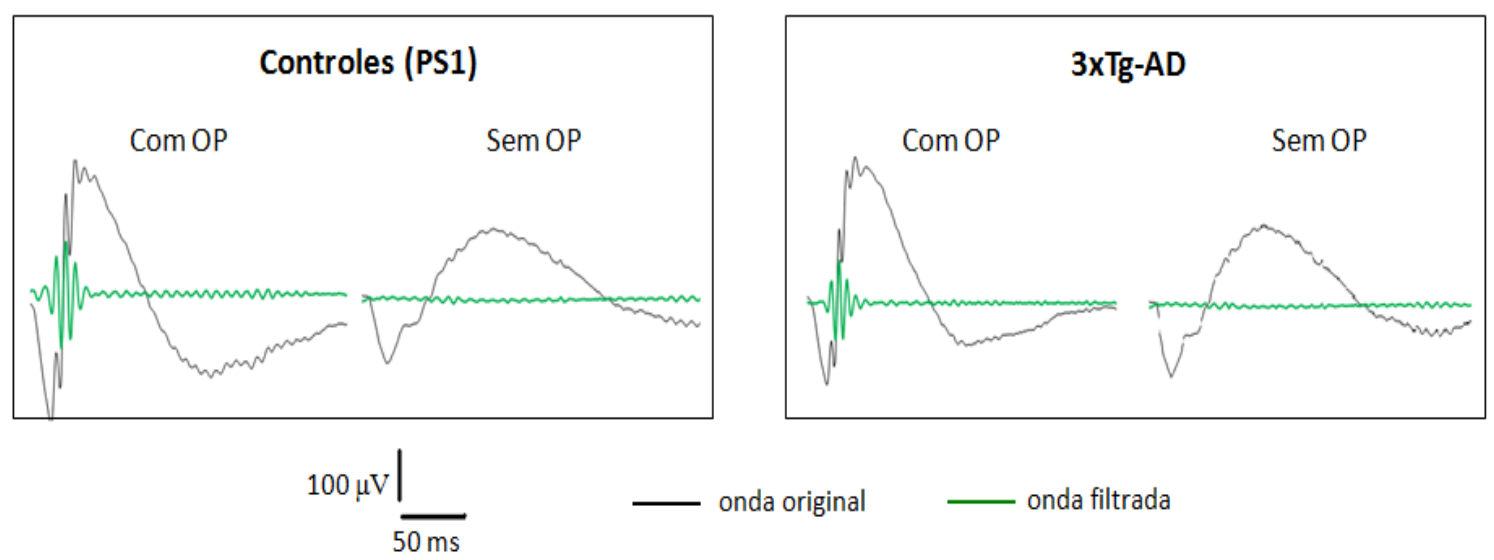

Figura 19. Gráficos das respostas escotópicas máximas filtradas pelo programa MATLAB (passa banda: $100 \mathrm{~Hz}-$ $300 \mathrm{~Hz}$ ) dos camundongos controles b6;129 (PS1) e dos modelos de Alzheimer (3xTg-AD). O traçado em preto é a resposta escotópica máxima registrada originalmente pelo eletrorretinograma e o traçado em verde é o resultado da filtragem. Nota-se que estes componentes rápidos são bem evidentes nos grupos com OP e quase ausentes nos grupos sem OP.

Como citado anteriormente, as respostas que possuem potenciais oscilatórios do grupo controle e do grupo experimental assemelham-se muito aos ERGs de outros trabalhos que também utilizaram camundongos (Bayer et al, 2001; Saszik et al, 2002; Fu et al, 2005; Rakoczy et al, 2006; Harazny et al, 2009) (Figura 20); por outro lado, as respostas de ambos os grupos com potenciais oscilatórios ausentes e enormes latências diferem dos trabalhos publicados com Mus Musculus.

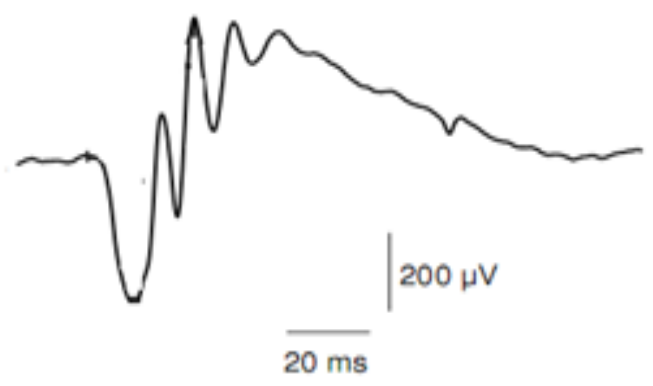

Figura 20. Resposta escotópica máxima (3 cd.s $/ \mathrm{m}^{2}$ ) do camundongo C57/B6 registrada pelo grupo do professor Jan Kremers (Harazny et al, 2009). 
Estes resultados discrepantes evidenciam a presença de respostas eletrofisiológicas diferentes entre os animais do mesmo grupo. Assim, a partir da filtragem das respostas escotópicas máximas $(100-300 \mathrm{~Hz})$, subdividimos os grupos controle e triplo-transgênico de acordo com a presença ou ausência dos potenciais oscilatórios; além disso, adicionamos um terceiro grupo controle de camundongos da linhagem C57/B6, cujas respostas escotópicas máximas são apenas do tipo com OP presentes, tornando-se um grupo referencial.

No diagrama abaixo, podemos observar os grupos e subgrupos formados:

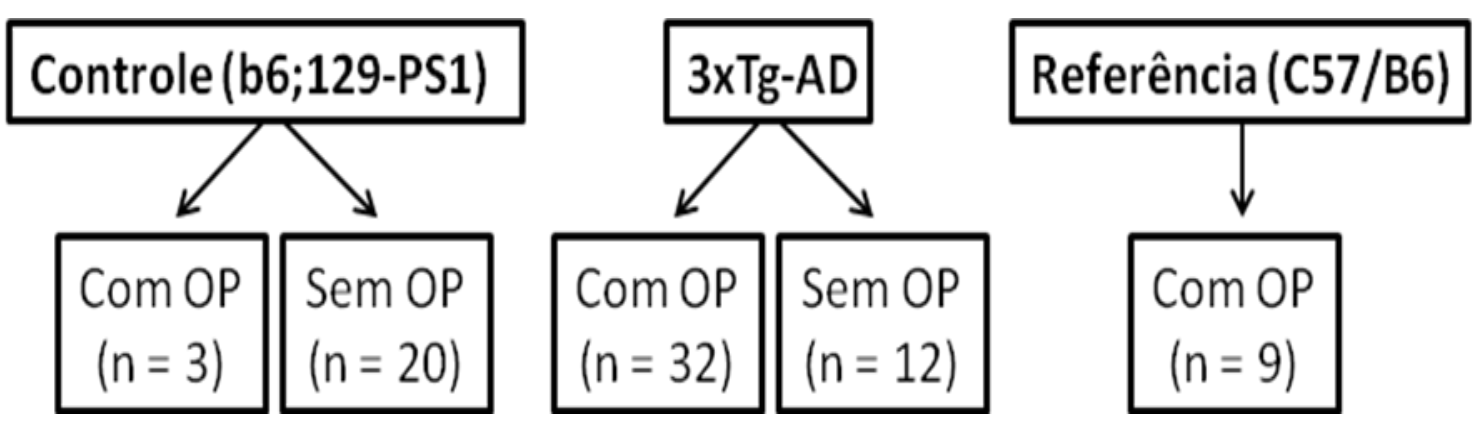

Figura 21. Diagrama dos grupos e subgrupos e a quantidade dos animais (n) utilizados neste trabalho. A divisão dos grupos foi realizada a partir do genótipo dos animais e a divisão dos subgrupos foi realizada a partir do fenótipo, neste caso, da presença ou ausência dos potenciais oscilatórios nas respostas escotópicas máximas.

A figura 22 ilustra os diferentes tipos de respostas de cada grupo/subgrupo e, através das respostas escotópicas em três intensidades diferentes, podemos observar que estes camundongos já apresentam respostas com características diferentes desde jovens. Além disso, a partir da intensidade de $3 \mathrm{~cd} . \mathrm{s} / \mathrm{m}^{2}$, notamos que a onda- $a$ pode ser observada em todos os grupos e os potenciais oscilatórios podem ser observados nos grupos com OP. 


\section{RESPOSTAS ESCOTÓPICAS EM 3 INTENSIDADES DIFERENTES}

b6;129 com OPs

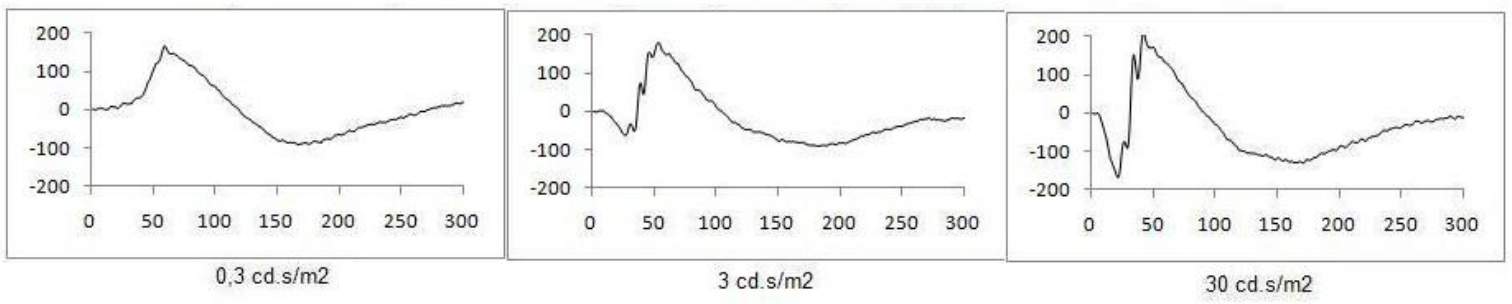

b6;129 sem OPs

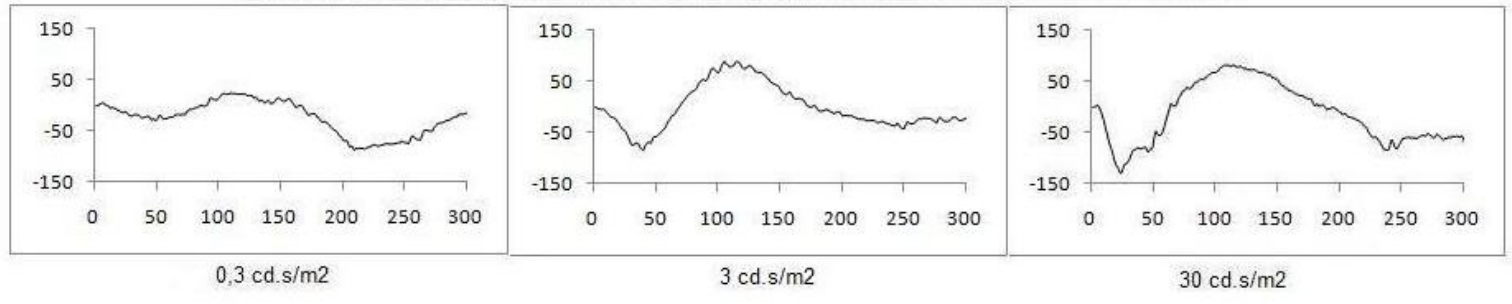

3xTg-AD com OPs

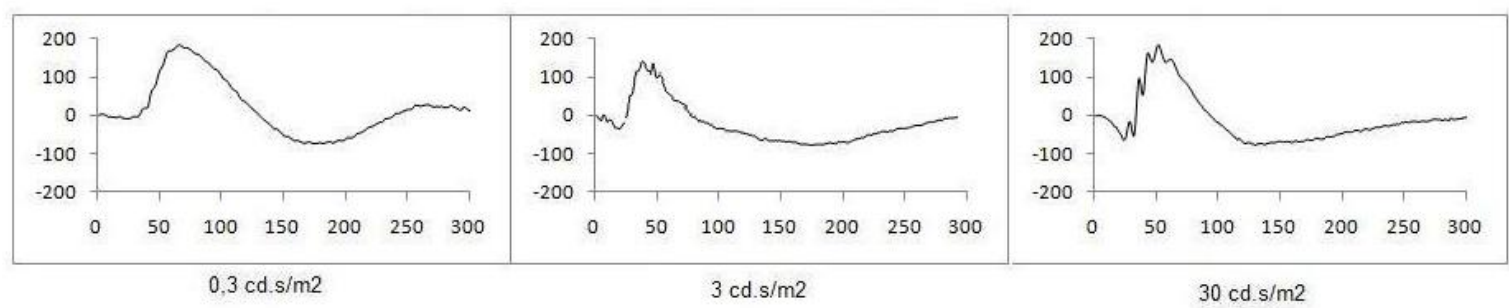

3xTg-AD sem OPs

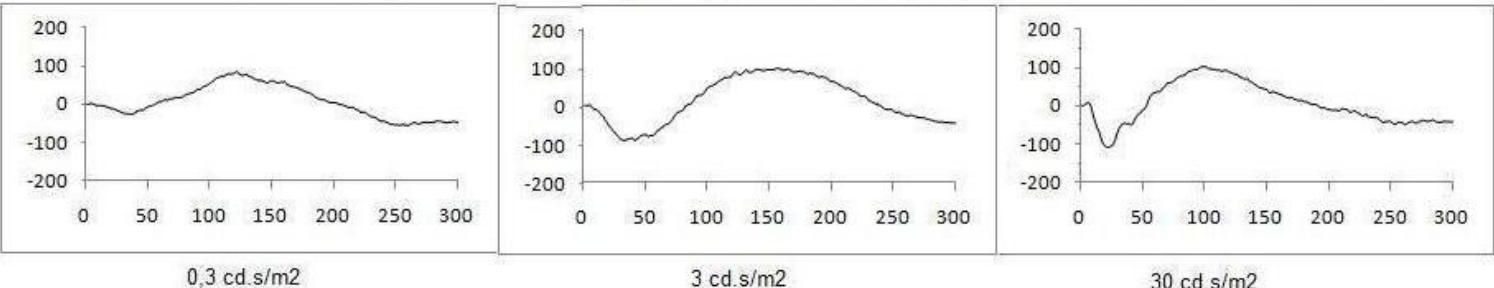

C57/B6

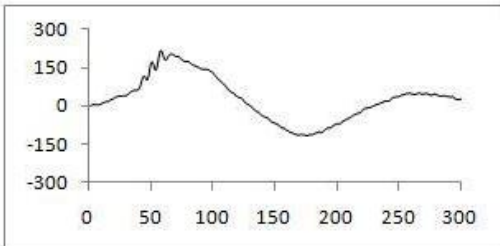

$0,3 \mathrm{~cd} . \mathrm{s} / \mathrm{m} 2$

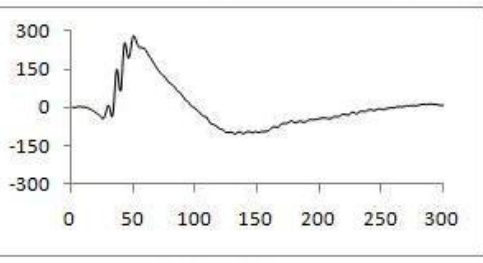

$3 \mathrm{~cd} . \mathrm{s} / \mathrm{m} 2$

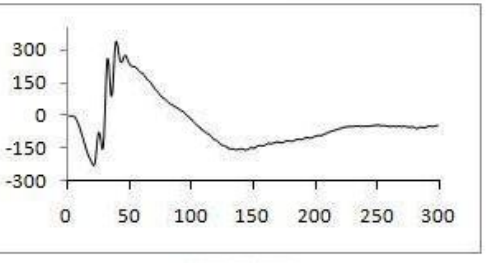

$30 \mathrm{~cd} . \mathrm{s} / \mathrm{m} 2$

Figura 22. ERGs escotópicos de cinco sujeitos diferentes em resposta a 3 intensidades: 0,3; 3 e $30 \mathrm{~cd} . \mathrm{s} / \mathrm{m}^{2}$.. ilustrando a ocorrência de respostas com e sem OPs em: camundongos b6;129 e 3xTg, respectivamente controle e transgênico para a Doença de Alzheimer, e no camundongo C57;B6. 
A medida da amplitude de resposta foi precedida da verificação de que os potenciais oscilatórios não influenciam os valores de amplitude e latência das ondas- $a$ e - $b$. Para isso, as respostas escotópicas máximas originais foram comparadas com os dados das mesmas ondas filtradas entre 1 e $100 \mathrm{~Hz}$ (Figura 23) e, segundo a análise do teste-t (Student), não houve diferença significativa entre elas $(p=0,83)$.

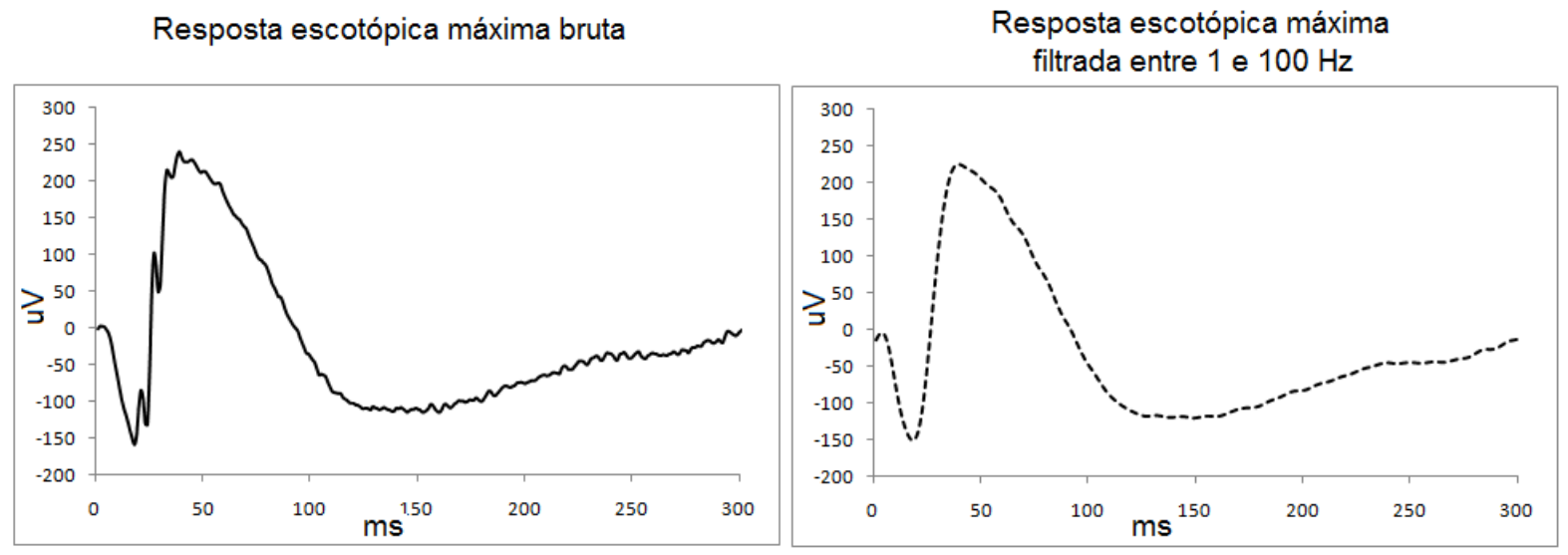

Figura 23. A esquerda, resposta escotópica máxima de um camundongo C57/B6 e a direita, a mesma onda filtrada com passa banda entre 1 e $100 \mathrm{~Hz}$, sem os potenciais oscilatórios.

\subsection{Onda-a}

Comparando as amplitudes da onda- $a$ dos diferentes grupos em cada mês (figura 25A), notamos que as médias dos grupos diferem significativamente aos seis, oito e doze meses de idade (tabela 1).

Na mesma figura (figura 25B), se confrontarmos cada grupo ao longo das idades, observamos que as amplitudes não variaram muito ao longo das seis idades, com exceção dos animais b6;129 com OP que tiveram uma queda acentuada nos últimos meses; este dado pode ser visualizado na tabela 2, que mostra uma diferença significativa das amplitudes da onda- $a$ do grupo b6;129 com OP entre os seis e doze meses de idade ( $p=$ $0,02)$ 

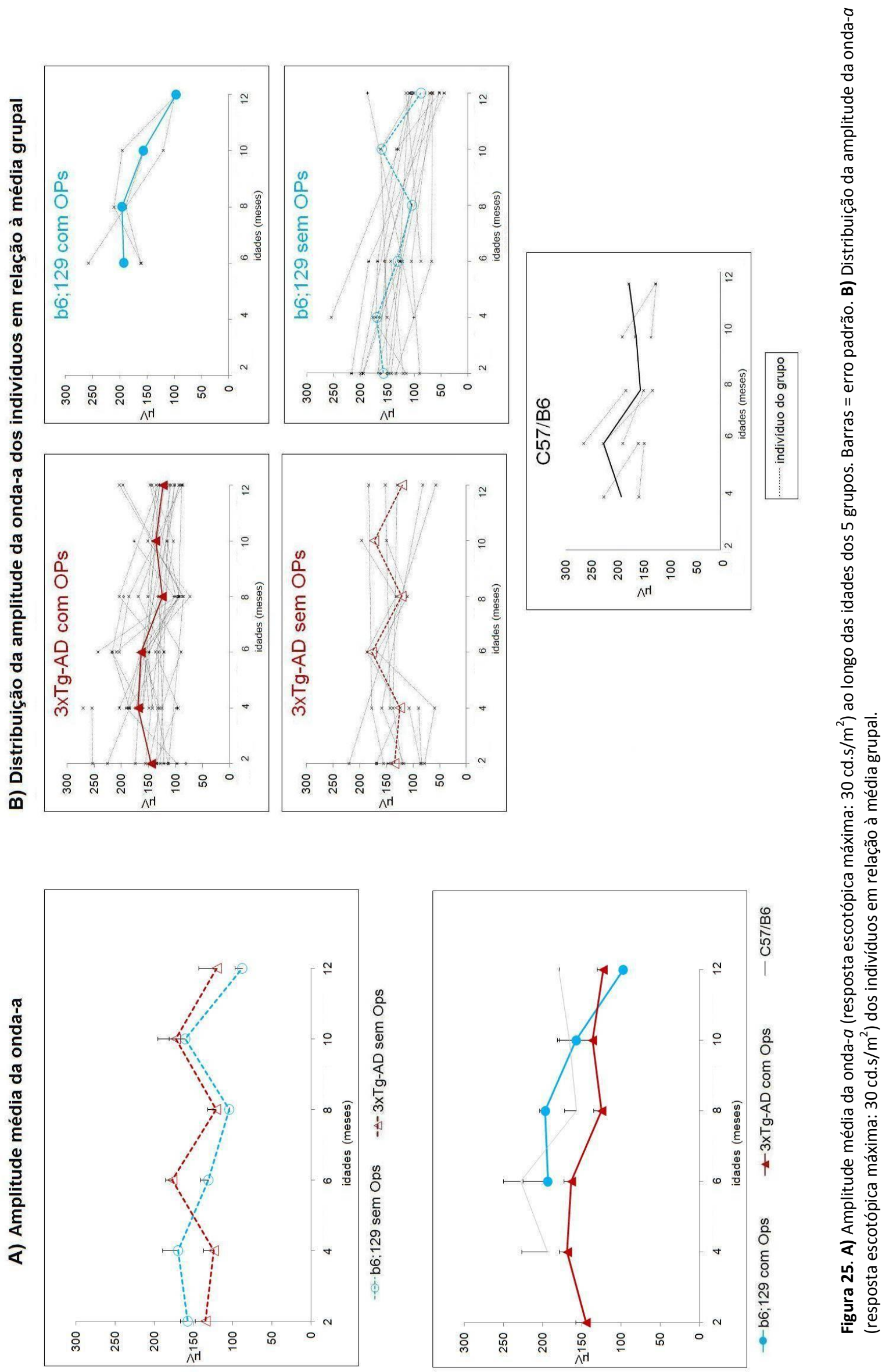
Tabela 1. Resultados da comparação da amplitude da onda- $a$ entre os cinco grupos (valores do nível de significância $p$ dos testes de hipóteses).

\section{Comparação entre os grupos (variáveis independentes)}

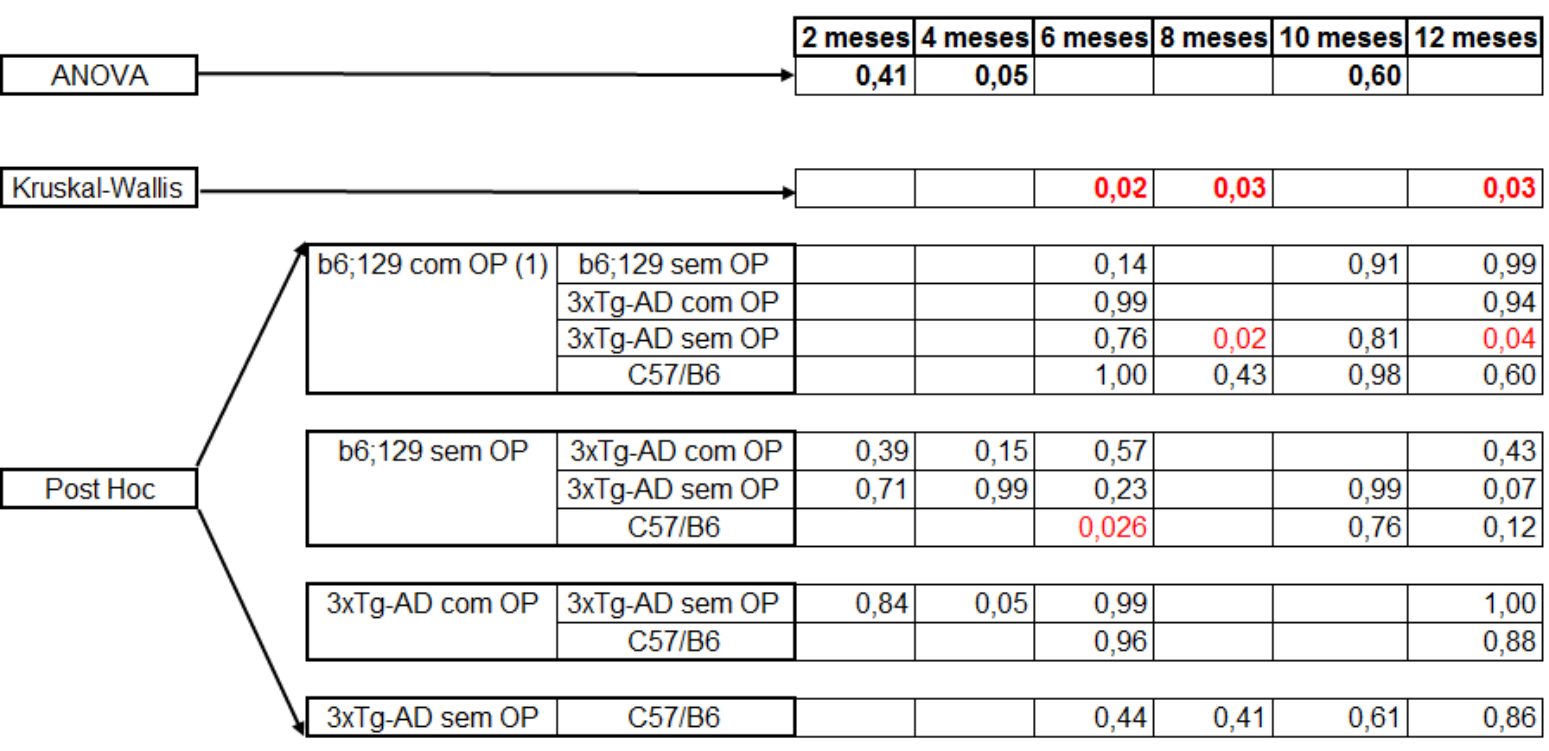

Tabela 2. Resultados da comparação da amplitude da onda- $a$ entre as diferentes idades de cada grupo (valores do nível de significância $p$ dos testes de hipóteses).

Comparação entre as idades (variáveis dependentes) - teste Wilcoxon

\begin{tabular}{|c|c|c|c|c|c|c|}
\hline & & b6;129 com OP & b6;129 sem OP & $3 \times T g-A D$ com OP & $3 \times \mathrm{Tg}-\mathrm{AD}$ sem OP & C57/B6 \\
\hline 2 meses & 4 meses & & & 0,49 & 0,46 & \\
\hline & 6 meses & & 0,13 & & 0,34 & \\
\hline & 8 meses & & & & 0,13 & \\
\hline & 10 meses & & & & 1,00 & \\
\hline & 12 meses & & 0,08 & 0,46 & & \\
\hline
\end{tabular}

\begin{tabular}{|c|c|c|c|c|}
\hline 4 meses & 6 meses & & & 0,93 \\
\hline & 8 meses & & & 0,11 \\
\hline & 10 meses & 0,28 & & 0,46 \\
\hline & 12 meses & 0,27 & 0,71 & 0,66 \\
\hline
\end{tabular}

\begin{tabular}{|r|r|r|r|r|r|r|}
\hline 6 meses & 8 meses & 1,00 & & & & \\
\hline & 10 meses & 0,28 & & & 0,46 & 0,10 \\
\hline & 12 meses & & 0,02 & & 0,93 & \\
\hline
\end{tabular}

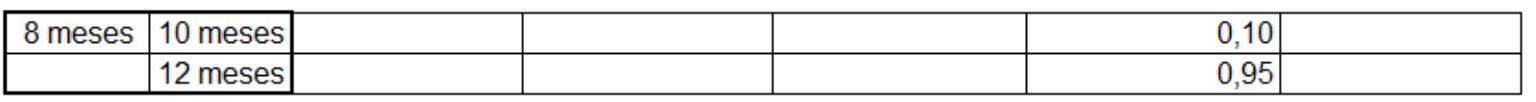

\begin{tabular}{|l|l|r|r|r|r|}
\hline 10 meses & 12 meses & 0,10 & 0,12 & 0,65 & 0,59 \\
\hline
\end{tabular}


Com relação às latências da onda- $a$, os cinco grupos tiveram médias semelhantes como podemos observar pela sobreposição das curvas e das barras do erro padrão entre os diferentes grupos na figura 26A. Além disso, a tabela 3 mostra que apenas os grupos b6;129 sem OP e 3xTg-AD sem OP tiveram uma diferença significativa aos 12 meses de idade.

Ao longo da idade, apenas os grupos b6;129 sem OP e 3xTg-AD sem OP variaram suas médias (tabela 4).

Individualmente, notamos que os camundongos do grupo controle b6;129 com OP distanciaram-se muito aos 12 meses de idade em relação à média do grupo, mas, também se nota que este grupo é composto por apenas 3 indivíduos (Figura 26B). 

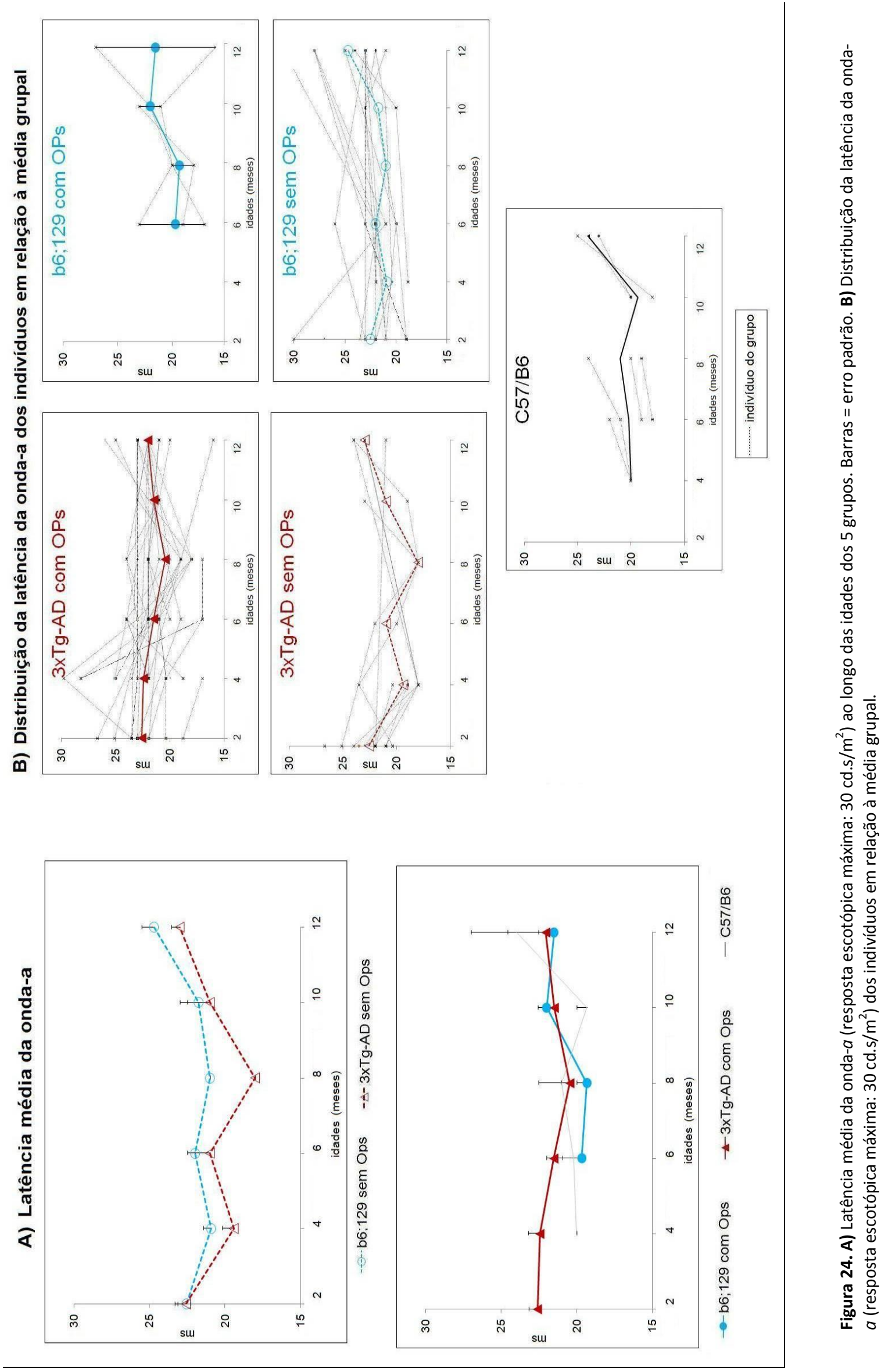
Tabela 3. Resultados da comparação da latência da onda- $a$ entre os cinco grupos (valores do nível de significância $p$ dos testes de hipóteses).

\begin{tabular}{|c|c|c|c|c|c|c|c|c|}
\hline & & & 2 meses & 4 meses & 6 meses & 8 meses & 10 meses & 12 meses \\
\hline Kruskal-Wallis & & & 0,94 & 0,52 & 0,26 & 0,67 & 0,89 & 0,021 \\
\hline & \multirow[t]{4}{*}{ b6;129 com OP } & b6;129 sem OP & & & 0,30 & & 0,99 & \\
\hline & & 3xTg-AD com OP & & & & & & \\
\hline & & 3xTg-AD sem OP & & & 0,45 & 0,68 & 0,94 & \\
\hline & & C57/B6 & & & 0,98 & 0,62 & 0,85 & \\
\hline & \multirow[t]{3}{*}{ b6;129 sem OP } & 3xTg-AD com OP & 0,99 & 0,62 & & & & 0,49 \\
\hline \multirow[t]{5}{*}{ Post Hoc } & & 3xTg-AD sem OP & 0,99 & 0,45 & 0,92 & & 0,99 & 0,013 \\
\hline & & C57/B6 & & & 0,36 & & 0,09 & 0,96 \\
\hline & \multirow[t]{2}{*}{$3 \times \mathrm{Tg}-\mathrm{AD}$ com OP } & 3xTg-AD sem OP & 1,00 & 0,05 & & & & 0,85 \\
\hline & & $\mathrm{C} 57 / \mathrm{B} 6$ & & & & 0,92 & & 0,93 \\
\hline & $3 x T g-A D$ sem OP & C57/B6 & & & 0,56 & & 0,14 & 0,53 \\
\hline
\end{tabular}

Tabela 4. Resultados da comparação da latência da onda- $a$ entre as diferentes idades de cada grupo (valores do nível de significância $p$ dos testes de hipóteses).

Comparação entre as idades (variáveis dependentes) - teste Wilcoxon

\begin{tabular}{|r|r|r|r|r|r|r|}
\cline { 3 - 7 } \multicolumn{1}{c|}{} & b6;129 com OP & b6;129 sem OP & 3xTg-AD com OP & 3xTg-AD sem OP & \multicolumn{1}{c|}{ C57/B6 } \\
\hline 2 meses & 4 meses & & & 0,09 & 0,71 & \\
\hline & 6 meses & & 0,73 & & 0,13 & \\
\hline & 8 meses & & & & 0,11 & \\
\hline 10 meses & & 0,01 & 0,71 & 1,00 & \\
\hline & 12 meses & & & & 0,04 & \\
\hline
\end{tabular}

\begin{tabular}{|r|r|r|r|r|r|l|}
\hline 4 meses & 6 meses & & & 0,24 & \\
\hline & 8 meses & & & & 0,01 & \\
\hline & 10 meses & 0,66 & & 0,71 & \\
\hline & 12 meses & & 0,27 & 0,10 & 0,12 & \\
\hline
\end{tabular}

\begin{tabular}{|r|r|r|r|r|r|r|}
\hline 6 meses & 8 meses & 0,78 & & & 0,08 & 0,10 \\
\hline & 10 meses & 0,27 & & & 0,41 & \\
\hline & 12 meses & & 0,02 & & 0,30 & \\
\hline
\end{tabular}

\begin{tabular}{|l|l|r|l|r|r|l|}
\hline 8 meses & 10 meses & 0,10 & & & 0,71 & \\
\hline & 12 meses & & & & 0,14 & \\
\hline
\end{tabular}

\begin{tabular}{|l|l|r|r|r|r|}
\hline 10 meses & 12 meses & 0,85 & 0,15 & 0,10 \\
\hline
\end{tabular}




\subsection{Onda-b}

A figura $27 \mathrm{~A}$ e a tabela 5 , mostram que para os grupos 3xTg-AD com OP, 3xTg-AD sem OP e b6;129 sem OP a amplitude da onda- $b$ varia pouco ao longo do desenvolvimento evoluindo de forma semelhante para esses grupos, com médias que oscilam em torno de $300 \mu \mathrm{V}$.

O grupo b6;129 com OP, dos seis aos oito meses de idade, apresentou amplitudes maiores quando comparado com os outros grupos, porém, teve uma queda relevante nos dois últimos meses, alcançando os grupos com menores amplitudes. Já o grupo C57/B6 manteve-se com as maiores amplitudes ao longo de todas as idades, com exceção dos oito meses. Infelizmente, estes dados não se encontram na tabela 4, pois a estatística não pode ser realizada com poucos sujeitos, mas, os resultados podem ser observados através da análise descritiva da figura 27A.

Observando a distribuição da amplitude da onda- $b$ individual, notamos que em todos os grupos houve uma variação muito grande (figura 27B). 

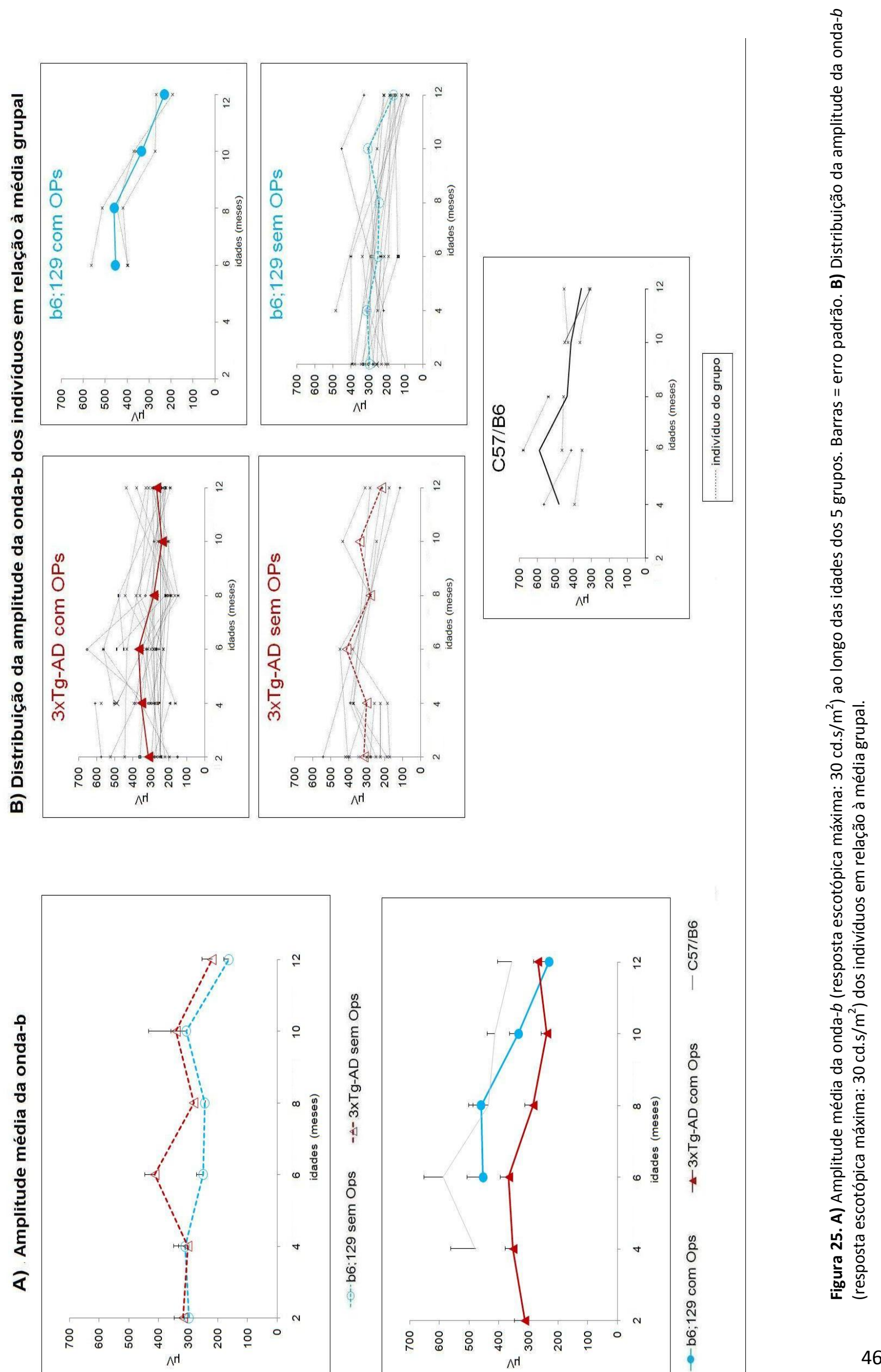
Tabela 5. Resultados da comparação da amplitude da onda- $b$ entre os cinco grupos (valores do nível de significância $p$ dos testes de hipóteses).

\section{Comparação entre os grupos (variáveis independentes)}

\begin{tabular}{|c|c|c|c|c|c|c|}
\hline & 2 meses & 4 meses & 6 meses & 8 meses & 10 meses & 12 meses \\
\hline ANOVA & 0,87 & 0,50 & & \begin{tabular}{l|l|}
0,01 \\
\end{tabular} & 0,11 & \\
\hline Kruskal-Wallis & & & 0,03 & & & 0,001 \\
\hline
\end{tabular}

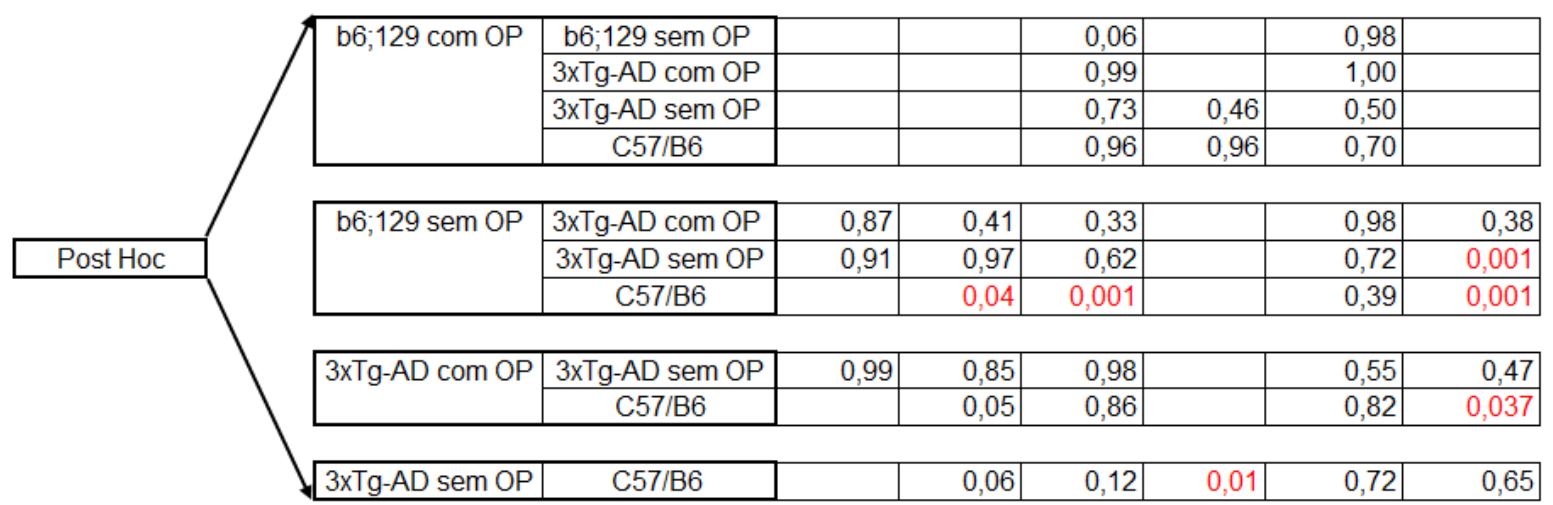

Tabela 6. Resultados da comparação da amplitude da onda- $b$ entre as diferentes idades de cada grupo (valores do nível de significância $p$ dos testes de hipóteses).

Comparação entre as idades (variáveis dependentes) - teste Wilcoxon

\begin{tabular}{|c|c|c|c|c|c|c|}
\hline & & b6;129 com OP & b6;129 sem OP & $3 \times \mathrm{Tg}-\mathrm{AD}$ com OP & 3xTg-AD sem OP & C57/B6 \\
\hline 2 meses & 4 meses & & & 0,23 & 0,91 & \\
\hline & 6 meses & & 0,31 & & 0,22 & \\
\hline & 8 meses & & & & 0,22 & \\
\hline & 10 meses & & & & 0,28 & \\
\hline & 12 meses & & 0,007 & 0,22 & 0,39 & \\
\hline
\end{tabular}

\begin{tabular}{|c|c|c|c|c|c|}
\hline 4 meses & 6 meses & & & 0,75 & 0,91 \\
\hline & 8 meses & & & 0,76 & 0,90 \\
\hline & 10 meses & 1,00 & & 0,68 & 0,75 \\
\hline & 12 meses & 0,27 & 0,10 & 0,37 & 0,65 \\
\hline
\end{tabular}

\begin{tabular}{|r|r|r|r|r|r|r|}
\hline 6 meses & 8 meses & 0,59 & & & 0,10 & 0,04 \\
\hline & 10 meses & 0,10 & & & 0,14 & 0,03 \\
\hline & 12 meses & & 0,01 & & 0,13 & 0,03 \\
\hline
\end{tabular}

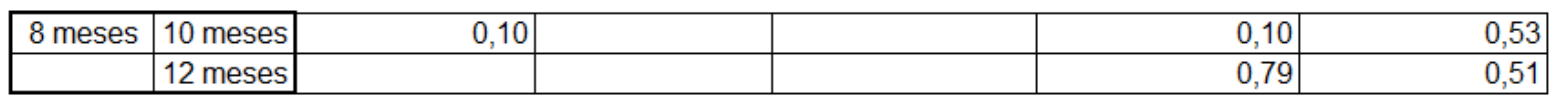

\begin{tabular}{|l|l|r|r|r|r|}
\hline 10 meses & 12 meses & 0,68 & 0,18 & 0,55 \\
\hline
\end{tabular}


O desenvolvimento médio da latência da onda- $b$ dos grupos pode ser observado na figura seguinte (figura 28A), que mostra a extraordinária diferença das respostas eletrofisiológicas dos diferentes animais, deixando evidente a presença dos dois subgrupos entre os camundongos b6;129 e entre os 3xTg-AD. Este dado também está explicito na tabela 7.

Nos resultados individuais da latência da onda-b (figura 28B) os grupos com OPs, incluindo a linhagem C57/B6, apresentam menor variabilidade, enquanto os grupos sem OPs estão mais dispersos e mais distantes desta curva. 

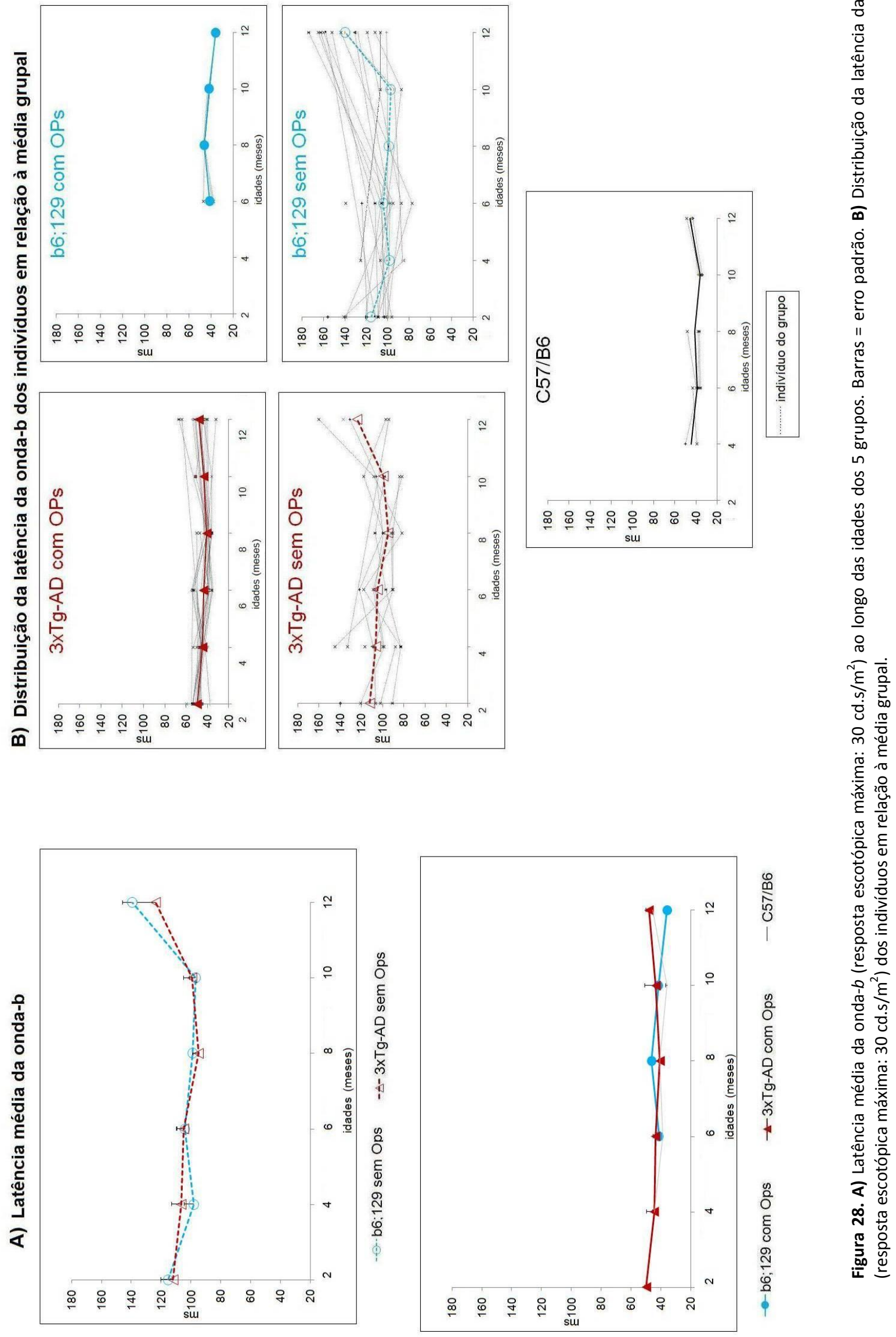
Tabela 7. Resultados da comparação da latência da onda-b entre os cinco grupos (valores do nível de significância $p$ dos testes de hipóteses).

\section{Comparação entre os grupos (variáveis independentes)}

\begin{tabular}{|c|c|c|c|c|c|c|}
\hline & 2 meses & 4 meses & 6 meses & 8 meses & 10 meses & 12 meses \\
\hline ANOVA & & 0,001 & & & & 0,001 \\
\hline \begin{tabular}{|l|} 
Kruskal-Wallis \\
\end{tabular} & 0,001 & & 0,001 & 0,003 & 0,01 & \\
\hline
\end{tabular}

\begin{tabular}{|c|c|c|c|c|c|c|c|c|}
\hline & \multirow[t]{4}{*}{ b6;129 com OP } & b6;129 sem OP & & & 0,001 & & 0,001 & 0,001 \\
\hline & & 3xTg-AD com OP & & & 0,99 & & 1,00 & 0,89 \\
\hline & & 3xTg-AD sem OP & & & 0,001 & 0,001 & 0,001 & 0,001 \\
\hline & & C57/B6 & & & 0,99 & 0,96 & 0,95 & 0,97 \\
\hline & \multirow[t]{3}{*}{ b6;129 sem OP } & 3xTg-AD com OP & 0,001 & 0,001 & 0,001 & & 0,001 & 0,001 \\
\hline \multirow[t]{5}{*}{ Post Hoc } & & 3xTg-AD sem OP & 0,86 & 0,67 & 1,00 & & 0,99 & 0,46 \\
\hline & & C57/B6 & & 0,001 & 0,001 & & 0,001 & 0,001 \\
\hline & \multirow[t]{2}{*}{$3 x T g-A D$ com OP } & 3xTg-AD sem OP & 0,001 & 0,001 & 0,001 & & 0,001 & 0,001 \\
\hline & & C57/B6 & & 0,99 & 0,98 & & 0,99 & 0,95 \\
\hline & 3xTg-AD sem OP & C57/B6 & & 0,001 & 0,001 & 0,001 & 0,001 & 0,001 \\
\hline
\end{tabular}

Tabela 8. Resultados da comparação da latência da onda- $b$ entre as diferentes idades de cada grupo (valores do nível de significância $p$ dos testes de hipóteses).

Comparação entre as idades (variáveis dependentes) - teste Wilcoxon

\begin{tabular}{|r|r|r|r|r|r|r|}
\cline { 3 - 7 } \multicolumn{2}{c|}{} & b6;129 com OP & b6;129 sem OP & 3xTg-AD com OP & 3x Tg-AD sem OP & C57/B6 \\
\hline 2 meses & 4 meses & & & 0,14 & 0,28 & \\
\hline & 6 meses & & 0,26 & 0,28 & 0,003 & \\
\hline & 8 meses & & & 0,28 & 0,08 & \\
\hline & 10 meses & & 0,005 & 0,59 & & \\
\hline & 12 meses & & & & 0,59 & \\
\hline
\end{tabular}

\begin{tabular}{|r|r|r|r|r|r|r|}
\hline 4 meses & 6 meses & & 0,73 & 0,76 & 0,65 \\
\hline & 8 meses & & 0,34 & 0,02 & \\
\hline & 10 meses & 0,27 & 0,75 & & \\
\hline & 12 meses & 0,46 & 0,71 & 0,34 & \\
\hline
\end{tabular}

\begin{tabular}{|r|r|r|r|r|r|r|}
\hline 6 meses & 8 meses & 0,27 & & 0,34 & 0,28 & 0,10 \\
\hline & 10 meses & 1,00 & & 0,24 & & \\
\hline & 12 meses & & 0,01 & 0,59 & 0,11 & \\
\hline
\end{tabular}

\begin{tabular}{|l|l|r|r|r|r|r|}
\hline 8 meses & 10 meses & 0,10 & & 0,41 & & \\
\hline & 12 meses & & & 0,28 & 0,02 & \\
\hline
\end{tabular}

\begin{tabular}{|l|l|r|r|r|r|}
\hline 10 meses & 12 meses & 0,10 & 0,28 & 0,10 \\
\hline
\end{tabular}




\subsection{Potenciais Oscilatórios}

Os potenciais oscilatórios foram filtrados entre 100 e $300 \mathrm{~Hz}$ a partir da resposta escotópica máxima e, para a nossa análise, foram medidas as amplitudes dos cinco OPs separadamente (figura 29) dos três grupos: b6;120 com OP, 3xTg-AD com OP e C57/B6 (figura 30).

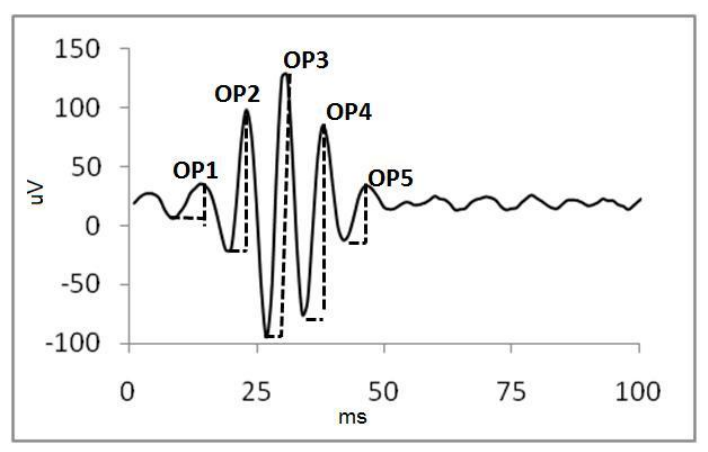

Figura 29. Marcações das amplitudes dos cinco potenciais oscilatórios presentes na resposta escotópica máxima de um animal do grupo b6;129 com OP.

b6;129 com OP

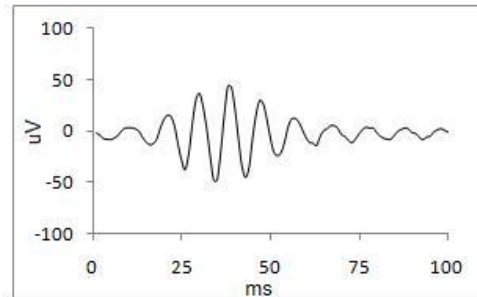

3xTg-AD comOP

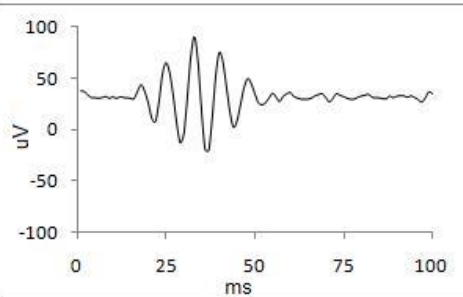

C57/B6

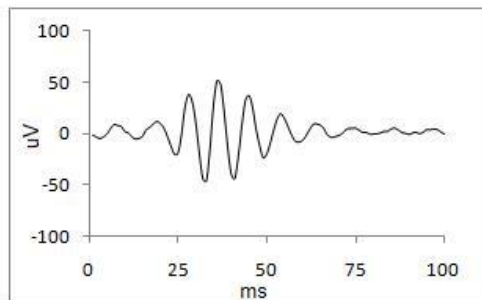

Figura 30. Potenciais oscilatórios dos grupos controles (b6;129 e C57;B7) e modelos de Alzheimer. Estes OPs foram filtrados digitalmente do MATLAB $(100-300 \mathrm{~Hz})$.

Comparando os três grupos com seis e doze meses de idade, notamos que não houve diferença significativa entre as amplitudes dos OPs 1 e 2, porém, a amplitude do OP 3 dos modelos de Alzheimer mostrou-se diferente do camundongo C57/B6 aos seis meses ( $p=$ 0,01 ) e as amplitudes dos OPs 4 e 6 foram estatisticamente diferentes comparando o grupo C57/B6 tanto com o B6;129 quanto com o 3xTg-AD aos seis e doze meses de idade (tabela 9). 
Tabela 9. Resultados da comparação dos potenciais oscilatórios entre os cinco grupos aos 6 e 12 meses de idade (valores de significância $p$ dos testes de hipóteses).

Comparação entre os grupos (variáveis independentes)

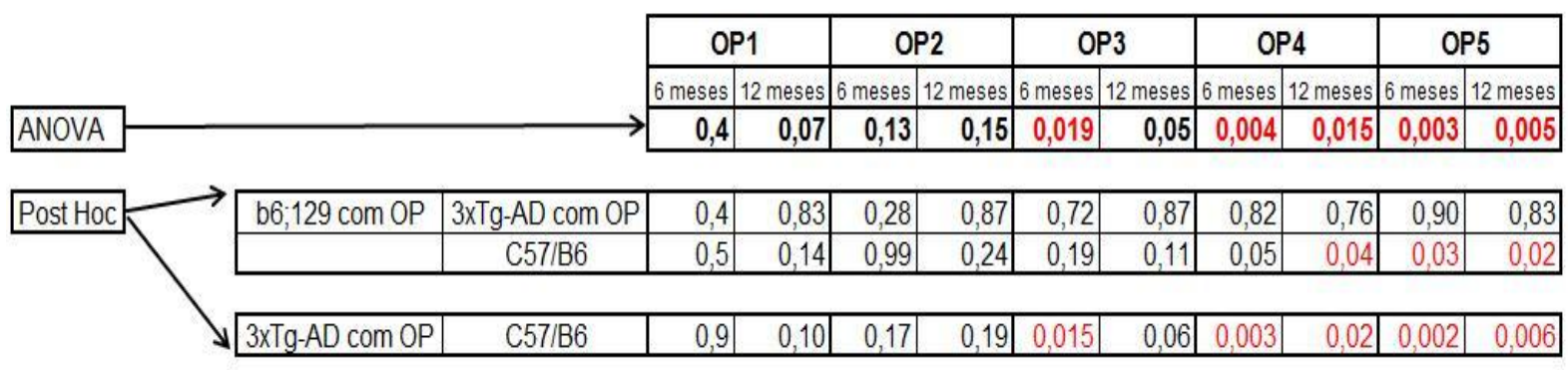

5.4. Resposta a diferentes freqüências temporais de estimulação (flicker)

Os animais sem OP e com OP também diferiram pronunciadamente em relação às suas respostas à estímulação intermitente. A figura 31 mostra que, para os grupos sem OP, as respostas ao flicker de $30 \mathrm{~Hz}$ possuem amplitudes menores do que as dos grupos com OPs. Observa-se também que os animais com OPs, mesmo nas frqüências temporais em que apresentam amplitudes mais baixas, em torno de $20 \mu \mathrm{V}$, ainda possuem os picos bem definidos.

$\mathrm{Na}$ estimulação de $12 \mathrm{~Hz}$ as diferenças de amplitude entre os grupos com e sem OPs são muito grandes e observa-se que os picos dos grupos com OP ocorrem de maneira abrupta enquanto que as respostas dos grupos sem OP são sustentadas durante a fase de luz do estímulo, formando um platô. 


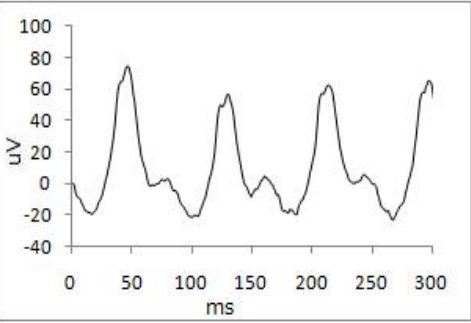

C57/B6
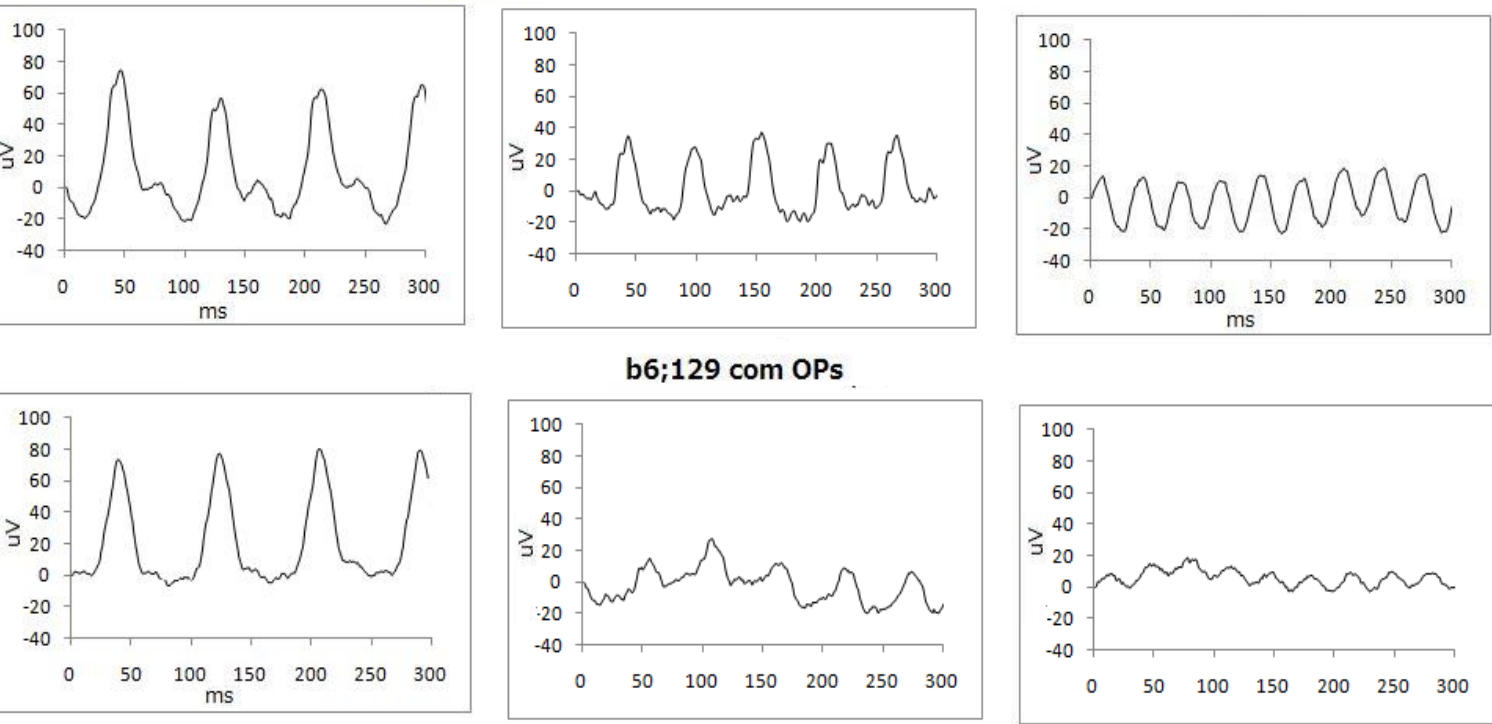

b6;129 sem OPs
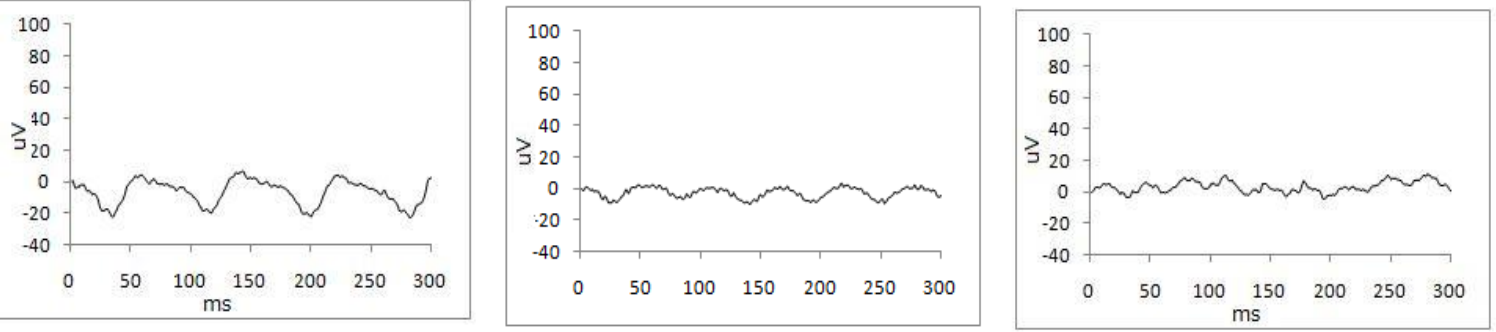

3xTg-AD com OPs
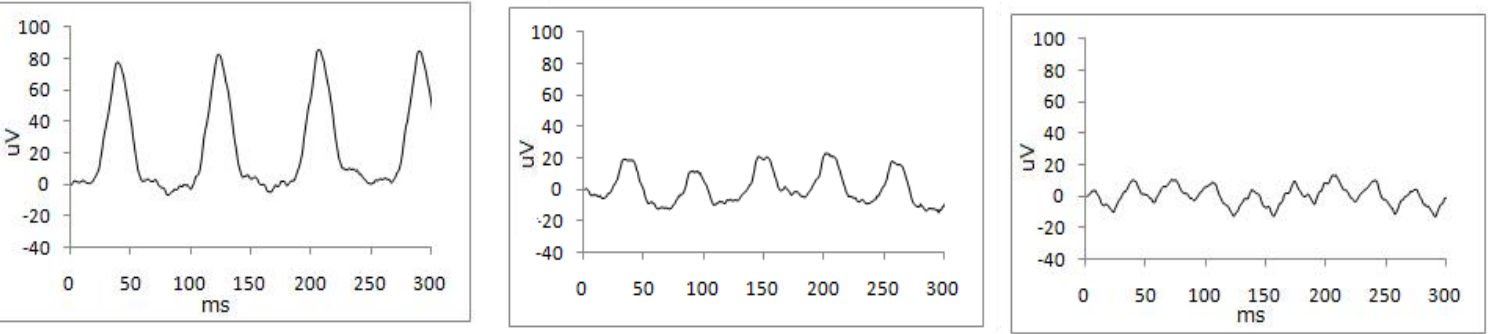

3xTg-AD sem OPs
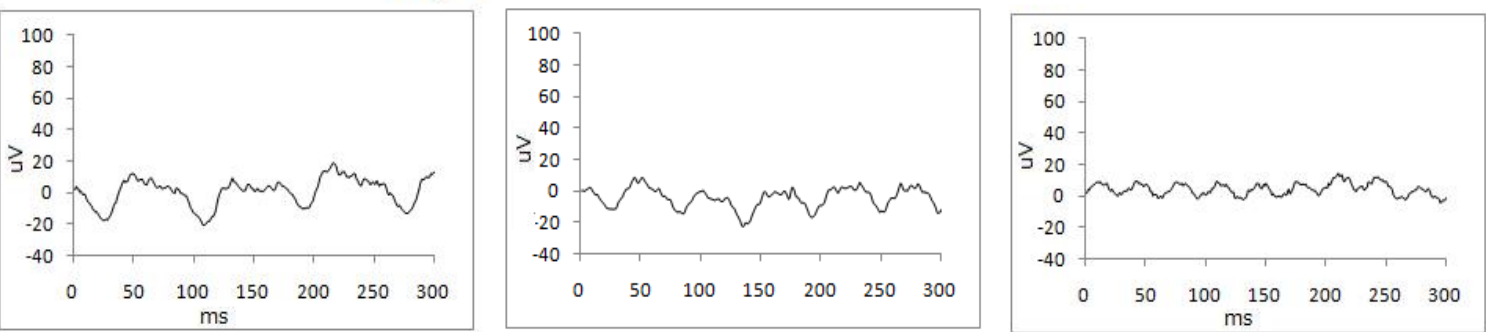

Figura 31. Exemplos de registros respostas eletrorretinográficas a estimulação intermitente nas freqüências temporais de 12,18 e $30 \mathrm{~Hz}$ de cinco sujeitos diferentes, todos com 4 meses de idade e cada um pertencente a um grupo. 
A partir da rotina em linguagem de programação MATLAB, elaborada por Givago da Silva Souza e colaboradores (Souza et al, 2010), A Figura 32 apresenta as amplitudes do 1은 harmônico da transformada de Fourier nas respostas às freqüências temporais de 12, 18 e $30 \mathrm{~Hz}$ dos cinco grupos ao longo do tempo.

As amplitudes do primeiro harmônico das respostas de estimulação intermitente dos grupos b6;129 e 3Tg-AD com OP, assim como as do C57;B6, diminuem com a freqüência de estimulação (Figura 32). Amplitudes bem menores foram encontradas nos camundongos controles e transgênicos sem OPs; em 12 e $18 \mathrm{~Hz}$, as amplitudes ficam em torno de $10 \mu \mathrm{V}$, enquanto que em $30 \mathrm{~Hz}$, a resposta é praticamente nula.

A tabela 11 mostra que não houve muita variação dos grupos ao longo das idades, apenas os animais b6;129 sem OP e 3xTg-AD com OP apresentaram algumas oscilações em 12 e $18 \mathrm{~Hz}$, porém, todos os grupos mantiveram-se constantes quando estimulados a $30 \mathrm{~Hz}$. 


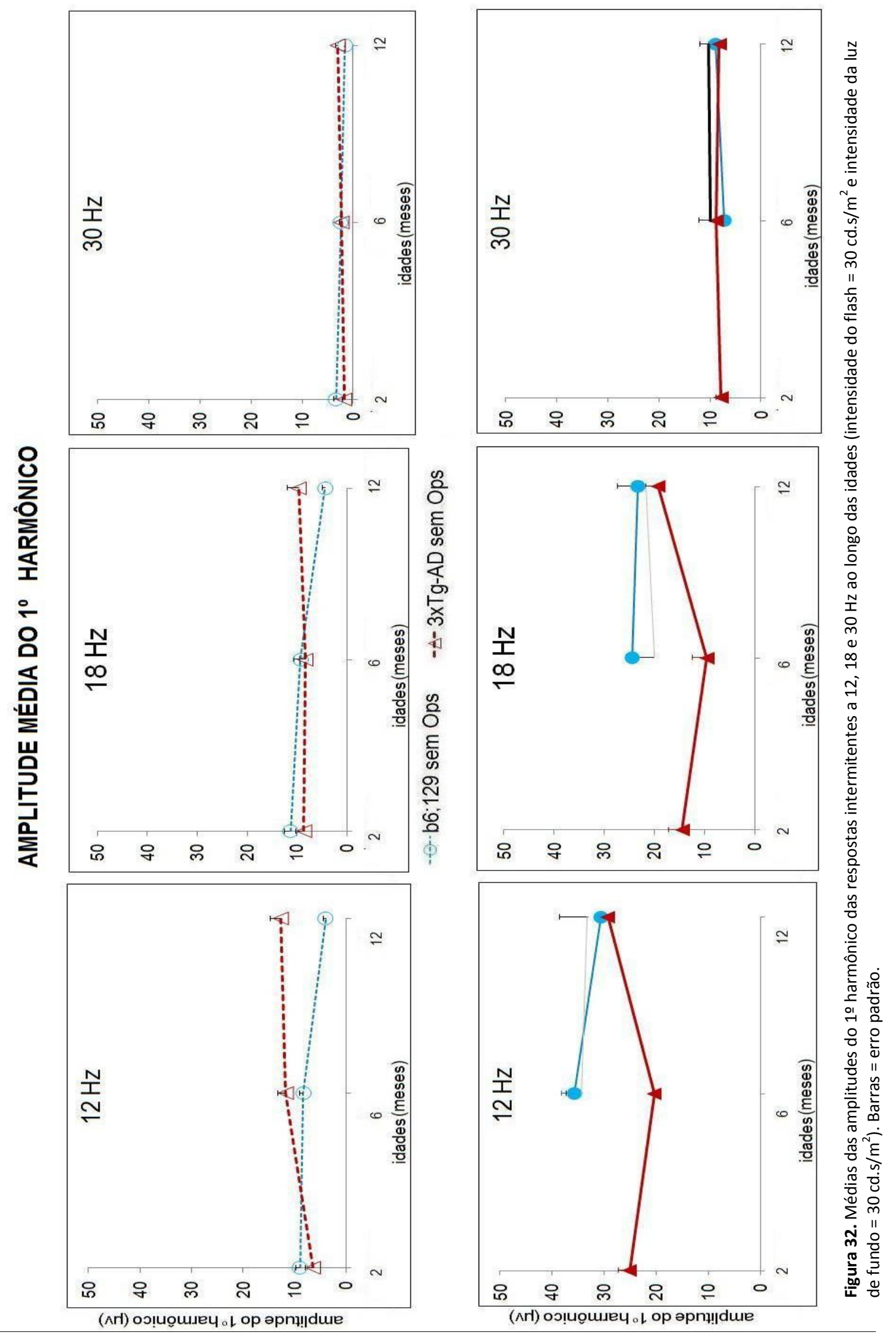


Tabela 10. Resultados da comparação das amplitudes do $1^{\circ}$ Harmônico nas freqüências de 12, 18 e $30 \mathrm{~Hz}$ entre os cinco grupos (valores do nível de significância $p$ dos testes de hipóteses).

\section{Comparação entre os grupos (variáveis independentes)}

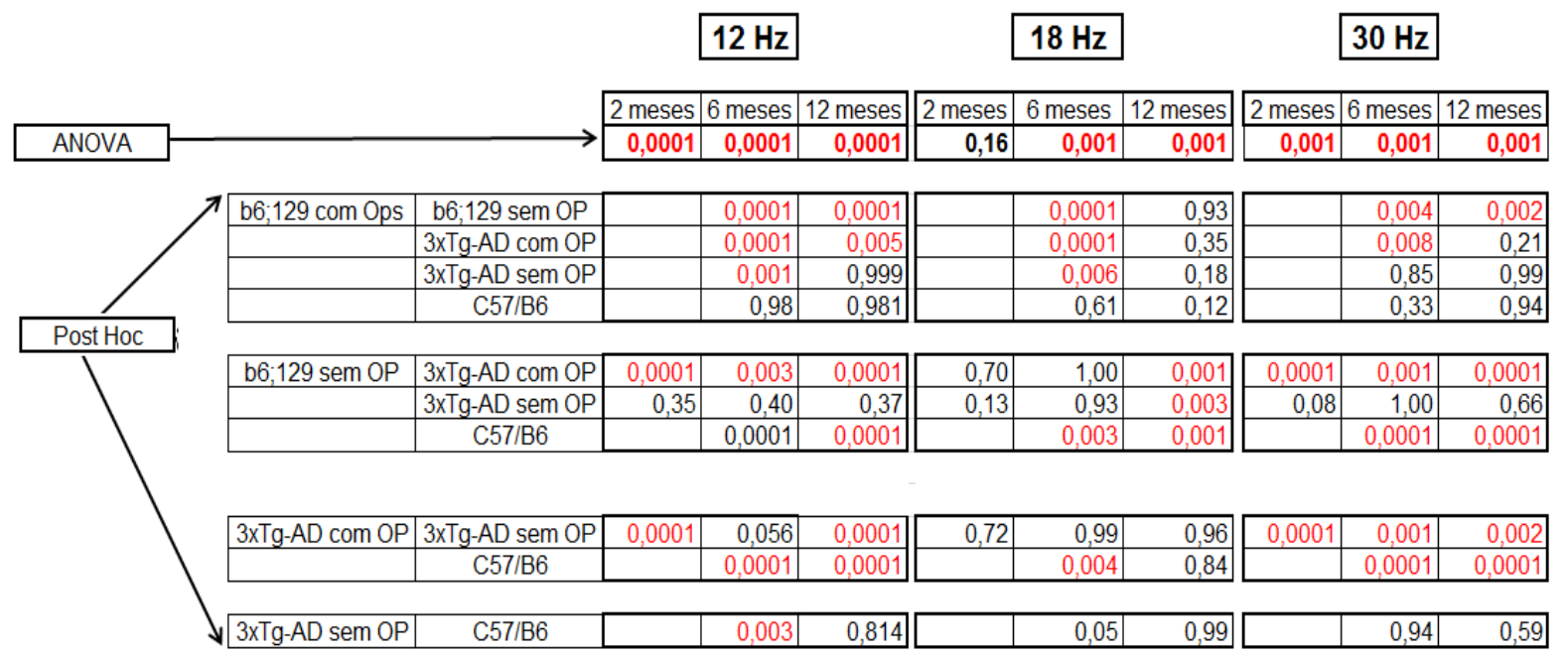

Tabela 11. Resultados da comparação das amplitudes do $1^{\circ}$ Harmônico nas freqüências de 12, 18 e $30 \mathrm{~Hz}$ entre as diferentes idades de cada grupo (valores do nível de significância $p$ dos testes de hipóteses).

Comparação entre as idades (variáveis dependentes) - teste de Wilcoxon

\section{$12 \mathrm{~Hz}$}

\begin{tabular}{|c|c|c|c|c|c|c|}
\hline & b6;129 com OP & b6;129 sem OP & 3xTg-AD com OP & 3xTg-AD sem OP & C57/B6 \\
\hline 2 meses & 6 meses & & 0,34 & 0,043 & 0,18 & \\
\hline & 12 meses & 0,18 & 0,01 & 0,043 & 0,14 & \\
\hline 6 meses & 12 meses & & & 0,50 & 0,18 & 1,00 \\
\hline
\end{tabular}

$18 \mathrm{~Hz}$

\begin{tabular}{|c|c|c|c|c|c|c|}
\hline & b6;129 com OP & b6;129 sem OP & 3xTg-AD com OP & 3xTg-AD sem OP & C57/B6 \\
\hline 2 meses & 6 meses & & 0,086 & 0,34 & 0,65 & \\
\hline & 12 meses & & 0.01 & 0,02 & 0,14 & \\
\hline 6 meses & 12 meses & 0,18 & 0,01 & 0,08 & 0,18 & 1,00 \\
\hline
\end{tabular}

$30 \mathrm{~Hz}$

\begin{tabular}{|c|c|c|c|c|c|c|}
\cline { 3 - 7 } \multicolumn{2}{l|}{} & b6;129 com OP & b6;129 sem OP & 3xTg-AD com OP & 3xTg-AD sem OP & C57/B6 \\
\hline 2 meses & 6 meses & & 0,12 & 0,68 & 0,18 & \\
& 12 meses & & 0,02 & 0,17 & 1,00 & \\
\hline
\end{tabular}

\begin{tabular}{|l|l|l|l|l|l|l|}
\hline 6 meses & 12 meses & 0,18 & 0,05 & 0,13 & 0,18 & 0,28 \\
\hline
\end{tabular}


O mesmo procedimento foi realizado para analisar as fases do 1 을 harmônico em 12 , 18 e $39 \mathrm{~Hz}$.

Em $12 \mathrm{~Hz}$, podemos notar que há uma dessincronização entre os grupos em função da idade e isto é causado pelas grandes variações da fase, todavia, os camundongos b6;129 sem OP mantém sua fase constante aos 2, 6 e 12 meses de idade (figura 33).

A figura 33 também mostra que, em 18 e $30 \mathrm{~Hz}$, todos os grupos estão praticamente paralelos ao eixo $x$ e, estatisticamente, a tabela 13 informa que a estimulação periódica a 30 $\mathrm{Hz}$ produz menos variações ao longo do tempo.

Por fim, se compararmos as fases do grupo b6,129 com OP com as do grupo C57/B6 não encontraremos diferença significativa, enquanto, ao fazer a combinação dos outros grupos entre si através da tabela 12, encontraremos diferenças estatísticas para todas as combinações. 

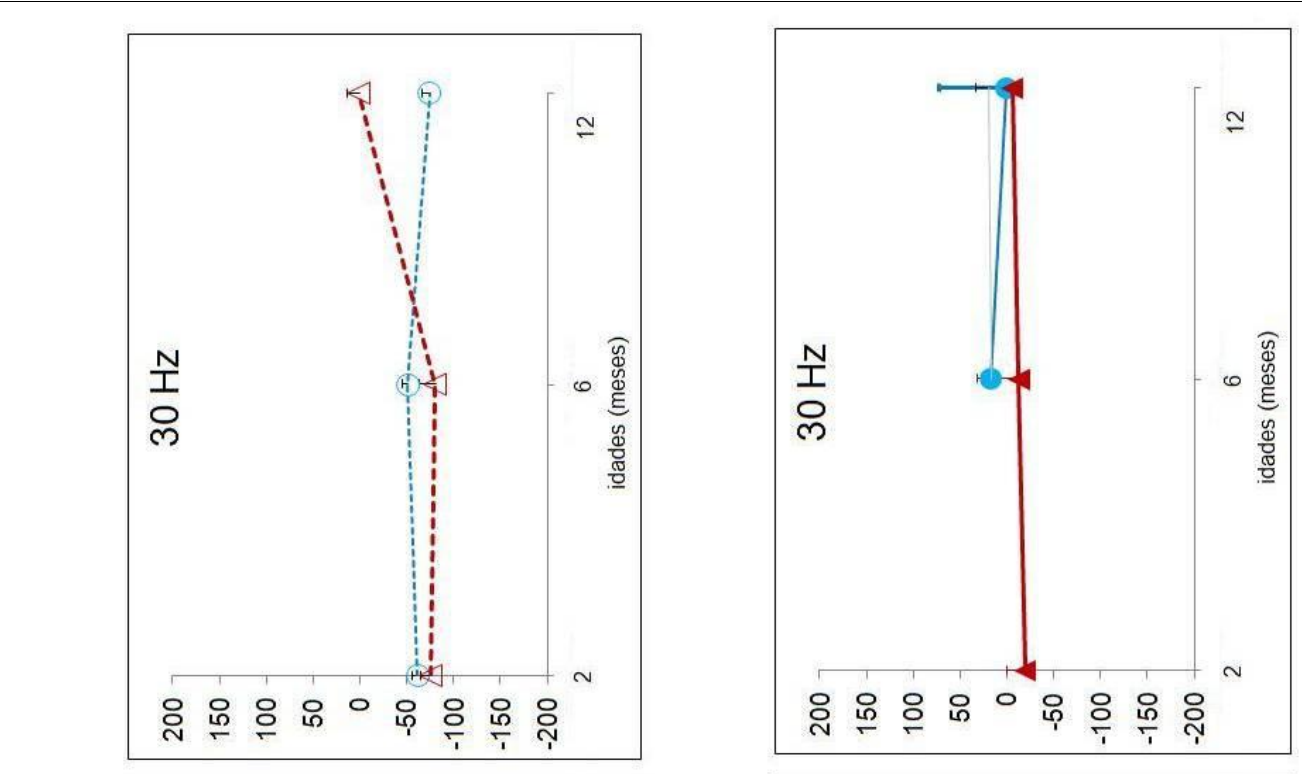

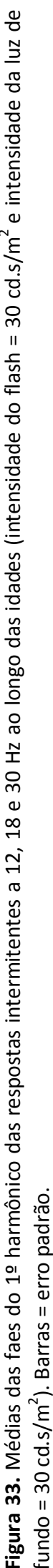
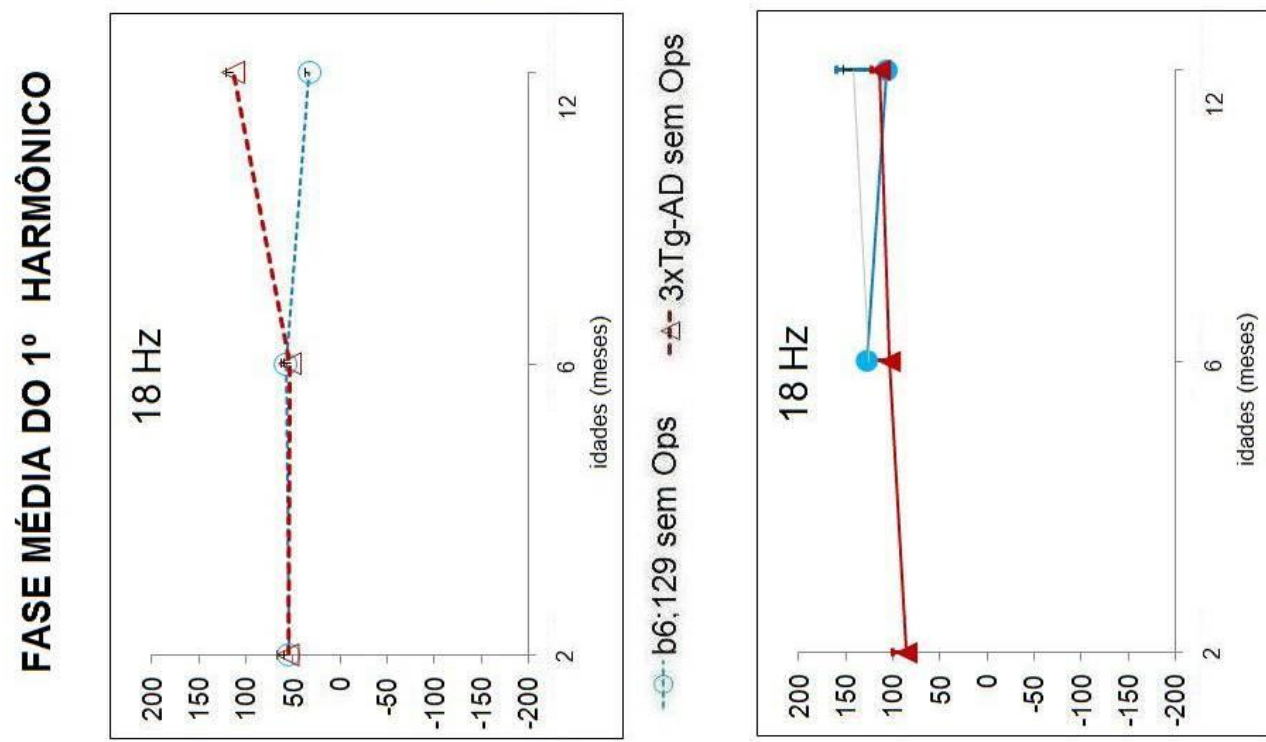

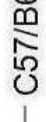
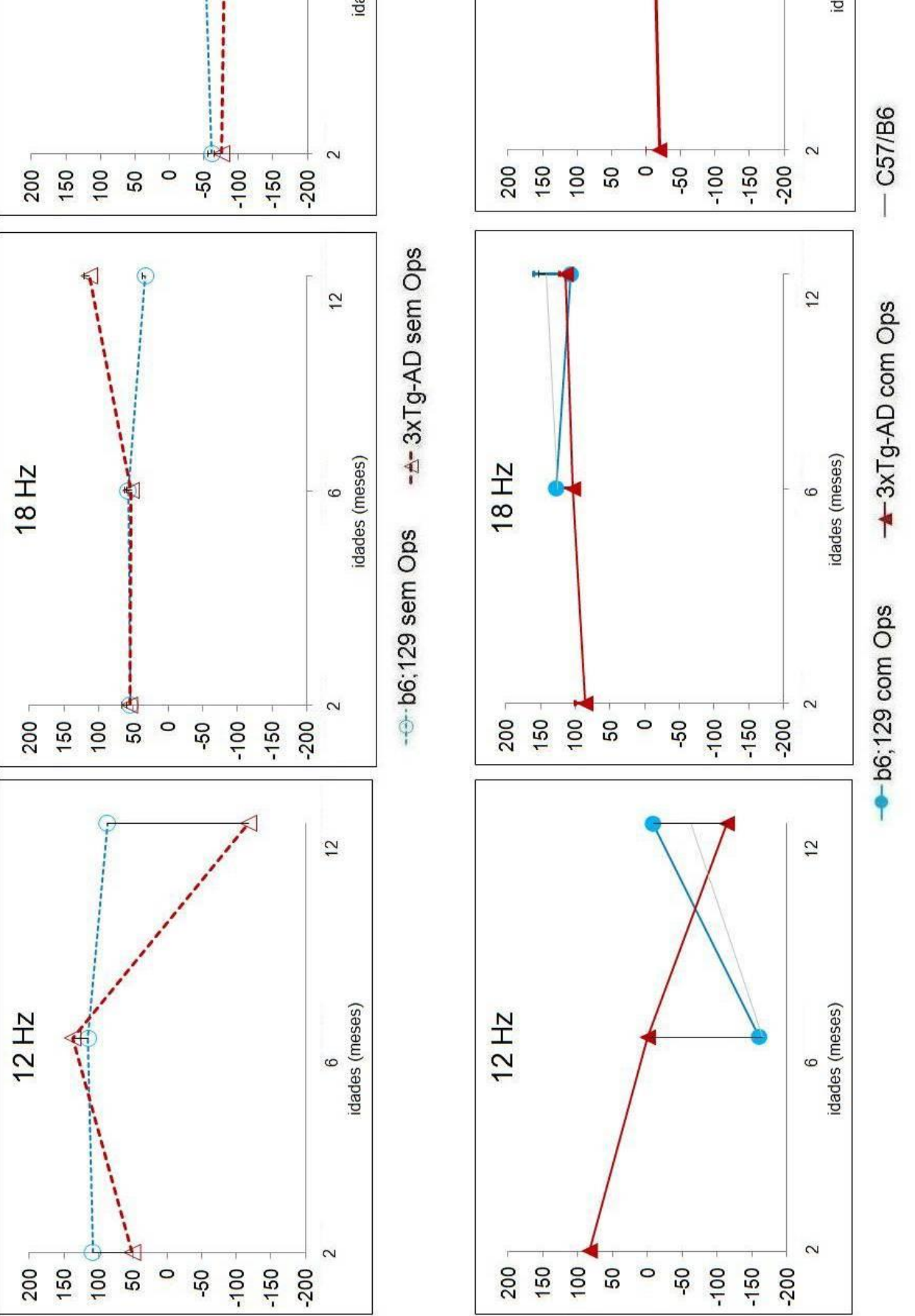

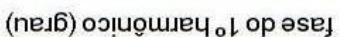

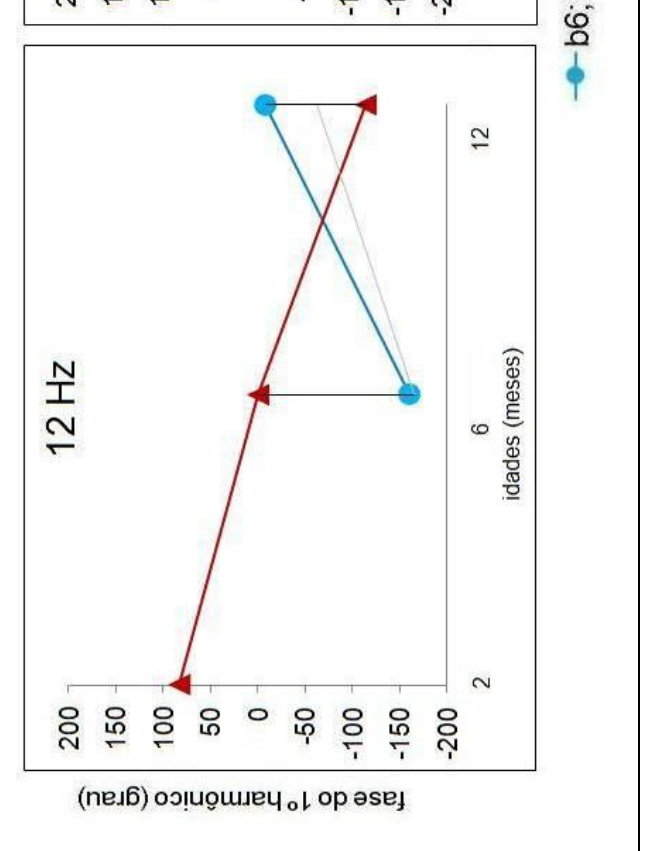

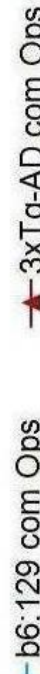

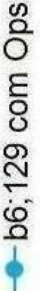
. 
Tabela 12. Resultados da comparação das fases do $1^{\circ}$ Harmônico nas freqüências de $12,18 \mathrm{e}$ $30 \mathrm{~Hz}$ entre os cinco grupos (valores do nível de significância $p$ dos testes de hipóteses).

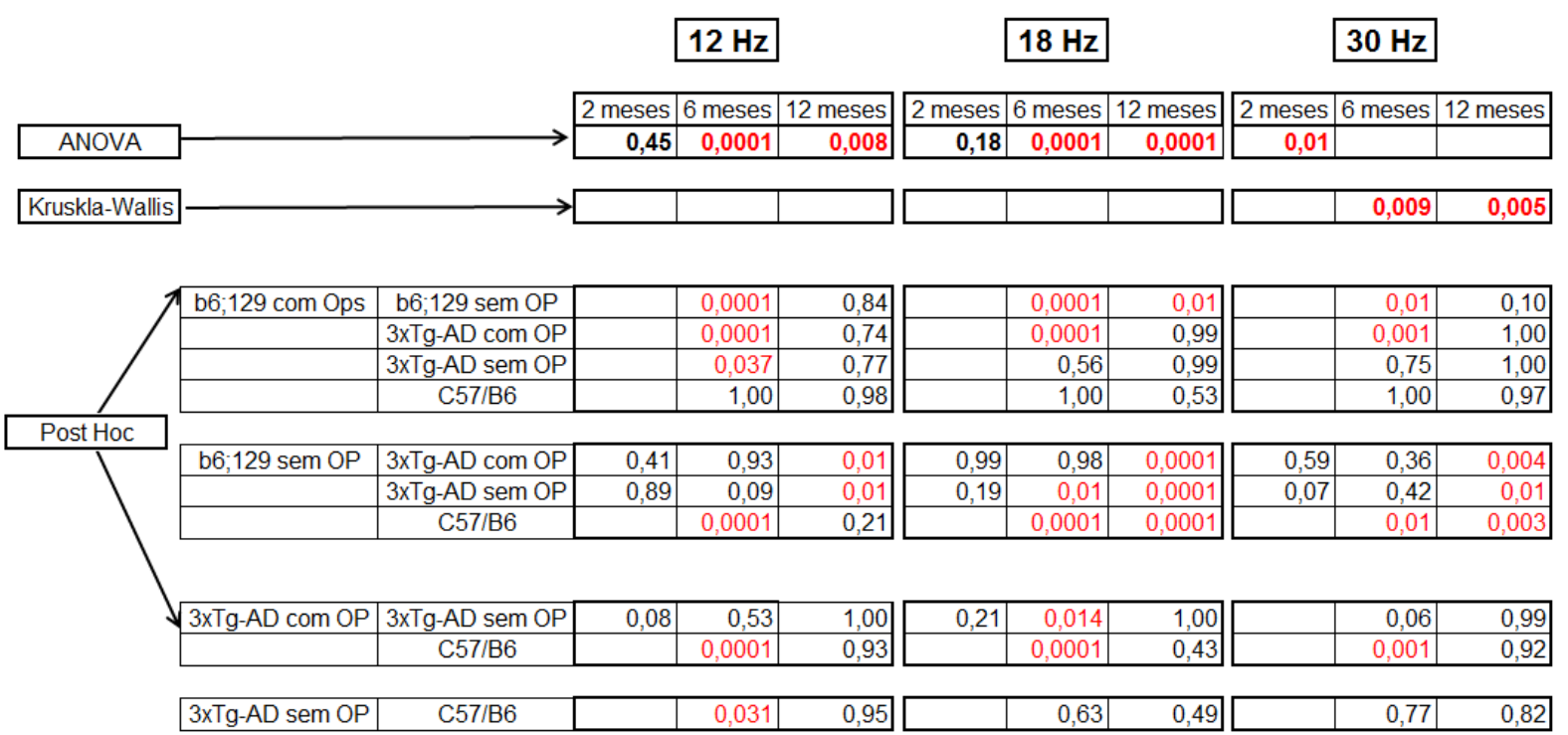

Tabela 13. Resultados da comparação das fases do $1^{\circ}$ Harmônico nas freqüências de 12,18 e $30 \mathrm{~Hz}$ entre as diferentes idades de cada grupo (valores do nível de significância $p$ dos testes de hipóteses).

Comparação entre as idades (variáveis dependentes) - teste de Wilcoxon

\section{$12 \mathrm{~Hz}$}

\begin{tabular}{|c|c|c|c|c|c|c|}
\hline & b6;129 com OP & b6;129 sem OP & $3 x T g-A D$ com OP & 3xTg-AD sem OP & C57/B6 \\
\hline 2 meses & 6 meses & & 0,37 & 0,04 & 0,65 & \\
\hline & 12 meses & & 0,06 & 0,23 & 0,46 & \\
\hline 6 meses & 12 meses & 0,18 & 0,02 & 0,08 & 0,65 & 0,10 \\
\hline
\end{tabular}

$18 \mathrm{~Hz}$

\begin{tabular}{|l|l|l|l|l}
\hline b6;129 com OP & b6;129 sem OP & 3xTg-AD com OP & 3xTg-AD sem OP & C57/B6
\end{tabular}

\begin{tabular}{|c|c|c|c|c|c|c|}
\hline 2 mese & 6 meses & 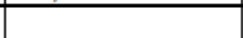 & 0,09 & 0,34 & 0,65 & \\
\hline & 12 meses & & 0,01 & 0,03 & 0,003 & \\
\hline 6 mese & 12 meses & 0,18 & 0,01 & 0,03 & 0,003 & 1,00 \\
\hline
\end{tabular}

$30 \mathrm{~Hz}$

\begin{tabular}{|l|l|l|l|l}
\hline b6;129 com OP & b6;129 sem OP & 3xTg-AD com OP & 3xTg-AD sem OP & C57/B6 \\
\hline
\end{tabular}

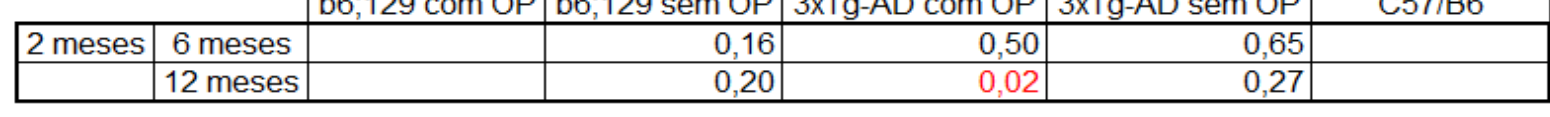

\begin{tabular}{|l|l|l|l|l|l|l|}
\hline 6 meses & 12 meses & 0,65 & 0,13 & 0,08 & 0,65 & 0,59 \\
\hline
\end{tabular}




\section{DISCUSSÃO}

Os eletrorretinogramas obtidos no presente trabalho mostraram dois tipos de respostas escotópicas tanto no grupo dos camundongos controles (b6;129- PS1) quanto nos modelos de Alzheimer (3xTg-AD). Em cada grupo, parte dos indivíduos apresentou ERGs com potenciais oscilatórios presentes e tempo implícito dentro da faixa esperada, enquanto em parte deles o ERG se apresentava sem potenciais oscilatórios e latência da onda-b muito aumentada. A proporção de ERGs sem OPs em cada grupo foi de $13 \%$ (20/23) nos controles e $28 \%(12 / 44)$ no 3xTg-AD. A partir destas características fenotípicas tão acentuadas, os grupos controle e experimental foram subdivididos em grupos com e sem OPs, tendo sido constituídos quatro subgrupos: b6;129 com OP, b6;129 sem OP, 3xTg-AD com OP e 3xTg-AD sem OP.

Para comparação com outros estudos da literatura e confirmação das condições experimentais do laboratório, incluímos como controle adicional um quinto grupo (camundongos da linhagem C57/B6), cujas respostas coincidiram com as de outros trabalhos publicados (Bayer et al, 2001; Saszik et al, 2002; Fu et al, 2005; Rakoczy et al, 2006; Harazny et al, 2009).

Assim, com a nova divisão dos animais, os resultados dos componentes do ERG foram comparados entre os cinco grupos e ao longo de seis idades: 2, 4, 6, 8, 10 e 12 meses.

Com relação à amplitude da onda- $a$, os animais não apresentaram muitas variações ao longo das idades; e ao compararmos os grupos entre si, apenas algumas diferenças significativas entre os grupos com OP e sem OP foram observadas (b6;129 com OP versus 3xTg-AD sem OP e b6;129 sem OP versus C57;B6 - tabela 1).

A latência da onda-a também se apresentou pouco alterada, de modo que os grupos exibiram dados semelhantes e se mostraram estáveis ao longo do tempo.

Com relação aos dados da amplitude da onda- $b$, podemos perceber que são muito semelhantes aos da amplitude da onda- $a$. Ao compararmos as amplitudes médias das ondas - $a$ e - $b$ (figuras 25 e 27), podemos observar várias semelhanças entre o desenvolvimento das 
duas ondas, uma vez que a diminuição e o aumento das amplitudes das ondas $-a$ e $-b$ coincidem no tempo.

Retomando os dados da latência da onda- $b$, podemos dizer que foram os resultados mais reveladores deste trabalho, pois, deixaram nítida a extraordinária variação das respostas eletrofisiológicas dos diferentes animais (figura 28A), uma vez que camundongos com OP foram quase duas vezes mais lentos em suas respostas do que os animais sem OP. Ressaltamos ainda, que dentre todos os resultados apresentados, a latência da onda-b exibiu a menor variabilidade individual, pois os animais do mesmo grupo responderam de forma muito semelhante (figura 28B).

A partir dos resultados das amplitudes e latências das ondas $-a$ e $-b$, podemos concluir que a ausência dos potenciais oscilatórios e o aumento da latência da onda- $b$ nos grupos b6;129 e 3xTg-AD sugerem que as células bipolares, amácrinas e ganglionares podem estar alteradas nestes animais (Wachtmeister, 1998).

As pequenas diferenças encontradas na amplitude da onda- $a$ entre os animais b6;129 com OP e os 3xTg-AD sem OP (tabela 1) poderiam ser atribuidas a alterações das células pós receptorais citadas acima.

A discordância entre os dados dos camundongos controle b6;129 sem OP e C57/B6 pode ser devida a diferenças entre linhagens, exemplificada por Reynold e colaboradores (Reynold et al, 2008) para duas outras linhagens de camundongos. Os resultados desses autores mostraram que linhagens diferentes podem apresentar ERGs diferentes. Na figura 35, os ERGs fotópicos das duas linhagens de camundongos estudadas por eles, mostram que a onda- $b$ dos animais C57BL/6JOlaHsd (B6) apresenta latência e amplitude menores do que a onda- $b$ dos 129S2/SvHsd (129) (Reynold et al, 2008). Nos mesmos registros, a onda-a não parece diferir entre os dois exemplos. 


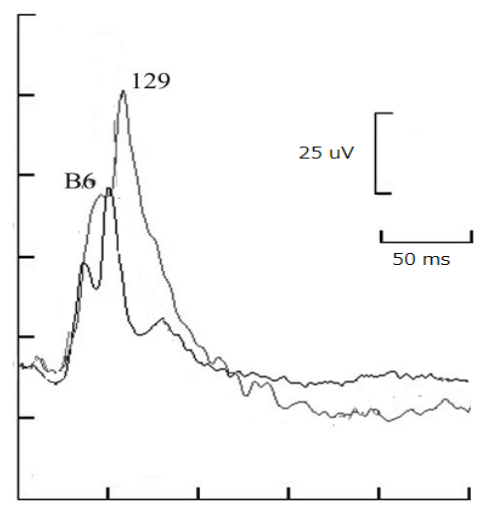

Figura 35. Respostas fotópica do camundongo B6 e 129 (Reynold et al, 2008).

Portanto, supondo que estas diferenças encontradas na amplitude da onda- $b$ possam ser causadas pela variabilidade individual ou da linhagem e, como nossos resultados indicam que não houve diferença significativa nas latências da onda-a entre os cinco grupos (tabela 3), podemos deduzir que os cones e os bastonetes, de uma forma geral, não são os responsáveis pelas respostas fenotípicas encontradas nos camundongos controles e 3xTg-AD sem OP.

Potenciais oscilatórios designam uma série de ondas que se sobrepõem à fase de subida da onda b, cuja origem é ainda pouco clara (Dong et al, 2004) e que segundo alguns autores representa a interação de células da retina interna, principalmente o efeito de retroalimentação negativa na camada plexiforme interna sobre a atividade de células bipolares, amácrinas e ganglionares (Wachtmeister, 1998). Apesar de refletirem atividade da retina interna, os OPs originam-se de vias de cones ou de bastonetes, e essa diferenciação é importante na utilização clínica dos OPs, pois estaria evidenciando diferentes patologias (Lei et al, 2006). Em estudo feito no ERG de camundongos Lei et al (2006) atribuem diferentes origens aos diferentes OPs. Os autores compararam o tipo selvagem C57BL/6J com camundongos cpfl1 que possuem apenas bastonetes e $\mathrm{rho}^{-/-}$que possuem apenas cones, concluindo, contrariamente ao geralmente descrito na literatura que os OPs ligados ao sistema de cones ocorrem antes dos ativados por bastonetes. Portanto, os OPs iniciais (OP1 e OP2) refletiriam atividades da via de cones enquanto os tardios refletiriam atividade conjunta de ambas as vias. 
No presente trabalho, a análise dos ERGs dos três grupos que possuem OPs não mostrou diferenças significativas no OP1 e no OP2 (Tabela 9) entre os grupos. Este resultado pode indicar uma normalidade funcional dos bastonetes e possivelmente nas conexões pósreceptorais desse sistema, visto que a ausência dos primeiros potenciais oscilatórios está relacionada a um tipo de cegueira noturna estacionária congênita (Wachtmeister, 1998), mas pela literatura mais recente, este resultado indicaria normalidade nas vias ligadas a cones (Lei et al, 2006).

Nenhuma diferença foi encontrada nas análises dos OP entre os animais controles (b6;129) e 3xTg-AD.

Entretanto, foram encontradas algumas diferenças significativas nos OP3, OP4 e OP5 entre os seguintes grupos:

$>$ OP3: entre os animais modelos de Alzheimer e C57/B6,

> OP4: entre os animais modelos de Alzheimer e C57/B6 e entre os controles PS1 e os C57/B6,

$>$ OP5: idem ao OP4

Estes achados podem ser explicados pela diferença das linhagens b6;129 e C57/B6, mas, também podem ser conseqüências de alterações funcionais. No caso do OP4 e OP5, as diferenças significativas podem estar relacionadas aos cones, pois, a relativa redução da amplitude dos potenciais tardios pode caracterizar distrofias destes fotorreceptores, incluindo o monocromatismo incompleto de bastonetes. Já as alterações no OP3 podem representar tanto diferenças quantitativas dos bastonetes, quanto dos cones (Wachtmeister, 1998).

Por fim, as respostas de flicker deixam clara a divisão dos subgrupos formados, mostrando o comprometimento no processamento temporal dos dois grupos sem OP, os quais em $12 \mathrm{~Hz}$, já apresentam respostas no nível do ruído (10 $\mu \mathrm{V})$, enquanto as respostas dos outros grupos são 2,5 a 3,5 vezes maiores (figura 32).

Comparando as fases dos $1^{\text {os }}$ harmônicos em 18 e $30 \mathrm{~Hz}$, percebemos que o estímulo mais rápido diminui a amplitude de resposta do ERG dos animais, o que é explicado pelo 
tempo de recuperação da retina, que aparentemente, parece não ser suficiente para um completo retorno à linha de base entre um flash e outro. Também podemos notar, que os camundongos sem OP são os grupos com menores respostas em ambas as freqüências (figura 33).

Uma das motivações para o presente trabalho foi a comparação de modelos de Alzheimer com modelos de glaucoma, dada a possibilidade de pontos em comum entre as duas patologias. De fato, existem algumas indicações de que processos similares estão envolvidos na patofisiologia do glaucoma e da Doença de Alzheimer. Podemos observar as seguintes semelhanças entre estas duas doenças:

- $\quad$ Sínteses de óxido nítrico podem ser envolvidas em muitas desordens neurológicas como a DA e o glaucoma (Mckinnon, 2003).

- $\quad$ O processo apoptótico envolvido na Doença Alzheimer e no glaucoma também são similares, envolvendo, principalmente, caspases 3 e $8, \mathrm{Bcl}-2$ e outros. Eventualmente, conduz um processo proteolítico anormal do precursor da proteína amilóide na membrana integral e uma acumulação anormal da proteína $\beta$-amilóide (Mckinnon, 2003).

- $\quad$ Em modelos animais de glaucoma, depósitos de $\beta$-amilóide nas células ganglionares da retina coincidem com a apoptose destas células. Além disso, injeções desta proteína no olho induzem a morte celular (Guo et al., 2007).

- O envolvimento da oxidação de proteínas através do excesso da produção de espécies reativas de oxigênio (como $\mathrm{O} \mathrm{OH}^{-}, \mathrm{H}_{2} \mathrm{O}_{2}$, radicais $\mathrm{O}$ etc) é comum na DA e no Glaucoma. (Tezel, 2006).

- A glicação de proteínas também tem um papel importante nestas duas doenças (Tezel, 2006).

As similaridades do Alzheimer e do glaucoma refletem no fato da memantina e a galantamina, que também é usada no tratamento da DA, estarem sob estudos para o tratamento do glaucoma, mostrando que qualquer tratamento efetivo contra DA (ou possivelmente outra doença neurodegenerativa) é potencialmente importante para a terapia do glaucoma (e possivelmente para a isquemia retinal e/ou desordens da retina). 
Além disso, ao intervir no trajeto da produção da $\beta$-amilóide os danos glaucomatosos em animais poderão ser evitados (Guo et al, 2007).

Estes dados sugerem que estas duas doenças podem estar intimamente ligadas, sugerindo que modelos de Alzheimer podem sofrer glaucoma ou outras desordens da retina.

O camundongo DBA/2J é o modelo mais usado para glaucoma, apresentando déficits anatômicos e funcionais na retina (Chang et al 1999). Este modelo é usado para testar possíveis tratamentos do glaucoma e estudos com epilepsia (Schuettauf et al, 2004). Novamente, mostrando que a neurodegeneração na retina pode ter uma relação com a neurodegeneração em áreas próximas do cérebro.

Comparando o modelo animal para Alzheimer utilizado neste trabalho (3xtG-AD) com os dados publicados pelo grupo de Jan Kremers, em camundongos modelos de glaucoma (DBA2J) (Harazny et al, 2009), podemos dizer que, apenas os modelos de glaucoma apresentaram uma diminuição das amplitudes da onda- $a$, da onda- $b$ e dos potenciais oscilatórios relacionada à idade. Porém, os camundongos do grupo controle, utilizados por Kremers, também apresentaram uma diminuição não patológica nas amplitudes destes mesmos componentes. Inferimos que esta diminuição longitudinal não foi encontrada em nenhum de nossos grupos, pois nossos dados indicam uma grande variabilidade individual (figuras 25B, 26B, 27B e 28B).

Os modelos de glaucoma também apresentaram uma latência maior conforme o aumento da idade, porém, segundo Harazny e colaboradores, esta diferença encontrada na latência pode ter sido ocasionada pela diminuição dos potenciais oscilatórios também encontrada no presente estudo com o modelo de Alzheimer.

Assim como nossos resultados, a resposta de flicker tanto do grupo controle, quanto do grupo experimental diminuiu conforme o aumento da freqüência temporal do estímulo; e a proporção: amplitude da onda de $30 \mathrm{~Hz} /$ amplitude de $12 \mathrm{~Hz}$ encontrada nos camundongos 3xTg-AD e nos DBA2J foi de, aproximadamente, 2,5 ou 3 . Além disso, tanto os modelos de glaucoma quanto os modelos de Alzheimer apresentaram uma amplitude do 1 o harmônico menor quando comparada com a de seus controles. Este mesmo resultado foi encontrado para a fase, pois, tanto os camundongos DBA2J, quanto os 3xTg-AD apresentaram um atraso 
na fase do 1 o harmônico, todavia, nossos modelos de Alzheimer apresentaram esta diferença apenas paras as freqüências de 18 e $30 \mathrm{~Hz}$.

Portanto, podemos dizer que as respostas de flicker dos camundongos modelos de Alzheimer e dos modelos de glaucoma foram semelhantes, apresentando uma diminuição da amplitude e da fase do 10 harmônico quando comparados com seus controles. Assim, como as respostas de flicker são geradas por células bipolares e os estímulos foram emitidos sob condições fotópicas e em altas freqüências temporais, estes resultados sugerem que as células bipolares de cones foram afetas tanto nos modelos de Alzheimer como nos modelos de glaucoma (Harazny et al, 2009).

Nossos resultados revelam que o ERG foi um método capaz de detectar alterações funcionais tanto nos camundongos b6;129 quanto nos 3xTg-AD, comprovando que a eletrorretinografia pode ser uma ótima ferramenta delimitadora de grupos, além de poder evidenciar variáveis fenotípicas de forma muito marcante.

Uma das hipóteses levantadas para justificar as respostas divergentes entre os grupos com e sem OPs encontradas neste trabalho estava baseada no estudo de Haines e colegas (Haines et al, 2001), o qual mostrava que a linhagem b6;129 estaria muito vulnerável em desenvolver um linfoma e, para o nosso estudo, estaria ocasionando as supostas alterações na retina. Esta hipótese foi excluída pois exames histopatológicos realizados em alguns animais, deram resultado negativo para investigação sobre linfoma, invalidando a tal hipótese.

Outra hipótese plausível para explicar os diferentes ERGs encontrados é a possibilidade de ter ocorrido uma mutação espontânea tanto no grupo controle quanto no grupo modelo de Alzheimer e, no nosso caso, é muito provável que esta mutação tenha ocorrido nas matrizes que foram importadas do Charles Rivers Lab, explicando assim, o grande número de animais sem potenciais oscilatórios (Neitz, com pess).

Nesta interpretação, as alterações eletrofisiológicas da retina podem estar associadas não apenas aos genes PS1, APP e tau e às placas senis, causadores da doença de Alzheimer, mas indiretamente e coincidentemente, a uma mutação não induzida. Acrescentamos que, como o único gene inserido em ambos os grupos foi o gene humano PS1, sugerimos que a 
mutação espontânea tenha ocorrido nesta proteína, o que explicaria as respostas divergentes tanto no grupo controle quanto no grupo modelo de Alzheimer.

Como citado na introdução, o gene PS1 é responsável pela formação da presenilina e esta, por sua vez, é um sub-componente da $\gamma$-secretase, responsável pela formação da proteína precursora do amilóide (APP) (Dawbarn \& Allen, 1995).

Estudos anteriores mostraram que o camundongo controle b6;129 com o gene PS1 inserido não manifesta fenótipos alterados, não apresentando alterações no desenvolvimento em fisiológicas da presenilina (Shen et al, 1997; Qian et al, 1998; Guo et al, 1999), mas, oportunamente, estas respostas divergentes encontradas neste trabalho podem ser justificadas pela mutação no gene PS1 através do trabalho de Dinet e colaboradores (2010), que mostraram a importância da APP no processo de diferenciação da retina, pois, camundongos deficientes em APP apresentaram inúmeras anormalidades neuronais: ${ }^{1} 1$. alteração da especialização de um subtipo de célula amácrina, $\mathbf{2}$ alteração na estrutura laminar da camada plexiforme interna, ${ }^{3}$ aumento das células horizontais $\mathrm{e}^{4}$ danos nas sinapses (Dinet et al, 2010). Estes resultados estariam coerentes com o aumento da latência da onda- $b$ encontrado em nossos camundongos.

Outra hipótese é que estas disfunções eletrofisiológicas da retina apresentadas por alguns camundongos controles b6;129-PS1 e alguns 3xTg-AD não estão relacionadas com o modelo de Alzheimer, propriamente dito, pois estes animais apresentaram um aumento da latência da onda- $b$ e um platô no pico das respostas de flicker já a partir dos 2 meses de idade, ou seja, não dependente de envelhecimento. Este achado exclui a possibilidade de que a $\beta$-amilóide e os emaranhados neurofibrilares tenham relação com as alterações encontradas no ERG pois os camundongos 3xTg-AD apresentam a $\beta$-amilóide entre três e quatro meses e os emaranhados neurofibrilares a partir dos dezoito meses de idade (Oddo et al 2003).

Em continuidade à investigação das causas das diferenças dos ERGs encontrados, a etapa seguinte deste trabalho será confirmar a expressão das proteínas tau, ps1 e APP, na retina desses camundongos, com uma extração do RNA a partir da retina; após uma reação 
com transcriptase reversa, obteremos o DNA complementar e faremos uma PCR específica para cada gene, detectando a expressão das proteínas. 


\section{REFERÊNCIAS}

Aprahamian, I., Martinelli, J. E., \& Yassuda, M. S. (2009). Doença de Alzheimer: revisão da epidemiologia e diagnóstico. Rev Bras Clin Med. (7): 27-35.

Arima, K. (2006). Ultrastructural characteristics of tau filaments in tauopathies: Immunoelectron microscopic demonstration of tau filaments in tauopathies. Neuropathology, $26,475-483$.

Barboni, M. T. S.; Pangeni, G.; Ventura, D. F.; Kremers, J. (2010). Phase changes in the chromaticity and luminance driven flicker electroretinograms (ERGs) of glaucoma patients. In: Annual Meeting of the Association for Research in Vision and Ophthalmology (ARVO 2010). Investigative Ophthalmology and Visual Science, 51: Eabstract 3264 .

Bayer, A.U., Ferrari, F., \& Erbb, C. (2002). High Occurrence Rate of Glaucoma among Patients with Alzheimer's disease. Eur. Neurol., 47, 165 - 168.

Berisha, F., Feke, G. T., Trempe, C. L. McMeel, J. W., \& Schepens, C. L. (2007). Retinal Abnormalities in Early Alzheimer's disease. Invest. Ophthalmol. Vis. Sci., 48:2285.

Blanks, J. C., Torigoe, Y, Hintons, D. R., \& Blanks R. H. (1996)(a). Retinal Pathology in Alzheimer's Disease I. Ganglion Cell Loss in Foveal/Parafoveal Retina. Neurobiology of Aging, 17 (3): 377-384.

Blanks, J. C., Schmidt, S. Y., Torigoe, Y, Porrello, K., V., Hintons, D. R., \& Blanks R. H. (1996)(b). Retinal Pathology in Alzheimer's Disease II. Regional Neuron Loss and Glial Changes in GCL. Neurobiology of Aging, 17 (3): 385-395.

Blurton-Jonesa, M., Kitazawaa, M., Martinez-Coriaa, H., Castelloa, N. A., Mullerb, J. F., Loringb, J. F., Yamasakl, T. R. Poona, W. W., Greena, K. N., LaFerla, F., M. (2009). Neural stem cells improve cognition via BDNF in a transgenic model of Alzheimer disease. PNAS, 106 (3): 13594-13599. 
Braak, H., \& Braak E. (1997). Neuropathological Assessments Staging of Alzheimer-Related Cortical Destruction. International Psychogeriatrics, Vol. 9, Suppl. 1, 257-261.

Buée, B., Bussière, T., Buée-Scherrer, V., Delacourte, A.,\& Hof, P. R. (2000). Tau protein isoforms, phosphorylation and role in neurodegenerative disorders. Brain Research Reviews, 33, 95-130.

Carroll, J. C., Rosario, E. R., Chang, L., Stanczyk, F. Z, Oddo, S., LaFerla, F. M., \& Pike, C. J. (2007). Progesterone and Estrogen Regulate Alzheimer-Like Neuropathology in Female 3xTg-AD Mice. The Journal of Neuroscience, 28, 27 (48):13357-13365.

Chaimowicz, F. (1997). A saúde dos idosos brasileiros às vésperas do século XXI: problemas, projeções e alternativas. Rev. Saúde Pública vol. 31.

Chen, J., Kanai, Y., Cowan, N. J., \& Hirokawa, N. (1992). Projection domains of MAP2 and tau determine spacings between microtubules in dendrites and axons. Nature, 360, 674677.

Costa, M. F. (2004). Perdas de função visual na distrofia muscular de Duchenne: visão de cores e visão de contrastes de luminância temporal e espacial. Tese de Doutorado, Instituto Psicologia, Universidade de São Paulo, São Paulo.

Cuthbertson, R. A. \& Mandel, T. E. (1985). Anatomy of the Mouse Retina. Endothelial CellPericyte Ratio and Capillary Distribution. Investigative Ophthalmology of Visual Science, 27, $1659-1664$.

Dagalarrondo, P. (2000). Psicopatologia e Semiologia dos Transtornos Mentais. Porto Alegre: Artmed.

Dinet, V., An, N., Ciccotosto, G. D., Bruban, J., Maoui, A., Bellingham, S. A., Hill, A. F., Ander, O. M., Nykjaer, A., Jonet, L. J., Cappai, R., \& Mascarelli, F. (2010). APP involvement in retinogenesis of mice. Acta Neuropathol. DOI10.1007/s00401-010-0762-2 
Dong CJ, Agey P, Hare WA. (2004) Origins of the electroretinogram oscillatory potentials in the rabbit retina. Vis Neurosci., 21:533-543.

Dräger, U. C., \& Olsen, J. F. (1981). Ganglion cell distribution in the retina of the mouse. Investigative Ophthalmology of Visual Science, 20 (3): 285-293.

Drewes et al. (1992). Mitogen activated protein (MAP) kinase transforms tau protein into an Alzheimer-like state. The EMBO Journal, 11 (6): 2131 - 2138.

Dutescu, R. M., Li, Qiao-Xin, Crowston, J., Masters, C. L., Baird, P. N., \& Culvenor, J. C. (2009). Amyloid precursor protein processing and retinal pathology in mouse models of Alzheimer's disease. Graefes Arch. Clin. Exp. Ophthalmol., 247, 9, 1213 - 1221.

Fath, T., Eidenmüller, J., \& Brandt, R. (2002). Tau-Mediated Cytotoxicity in a Pseudohyperphosphorylation Model of Alzheimer's Disease. The Journal of Neuroscience, 22, 9733-9741.

Fei, Y. (2003). Development of the cone photoreceptor mosaic in the mouse retina revealed by fluorescent cones in transgenic mice. Molecular Vision, (9): 31-42.

Ferri et al (2005). Global prevalence of dementia: a Delphi consensus study. The Lancet, 366, $2112-2117$.

Gargini, C., Terzibasi, E., Mazzoni, F., \& Strettoi, E. (2007). Retinal Organization in the retinal degeneration 10 (rd10) Mutant Mouse: a Morphological and ERG Study. J. Comp. Neurol., 500(2): 222-238.

Gautheron, V., Auffret, A., Mattson, M. P., Jean Mariani; Garabedian, B. V. (2009). A new and simple approach for genotyping Alzheimer's disease presenilin-1 mutant knockin mice. J Neurosci Methods., 181(2): 235-240.

Ghosh, K., Bujan, S., Haverkamp, S., Feigenspan, A, \& Wässle, H. (2004). Types of Bipolar Cells in the Mouse Retina. The Journal of Comparative Neurology, 469, $70-81$. 
Goedert, M., Klugand, \& A Crowther, R. A. Tau protein, the paired helical filament and Alzheimer'sdisease. Journal of Alzheimer's Disease, 9, 195-207.

Goldblum, D., Kipfer-Kauer, A., Sarra, G. S., Wolf, S., \& Frueh, B. E. (2007). Distribution of Amyloid Precursor Protein and Amyloid-BImmunoreactivity in DBA/2J Glaucomatous Mouse Retinas. Investigative Ophthalmology \& Visual Science, 48 (11): 5085 - 5090.

Goldgaber, D. et al (1987). Characterization and Chromosomal Localimtion of a cDNA Encoding Brain Amyloid of Alzheimer's Disease. Science, 239, 877-880.

Granit, R. (1968). The Development of Retinal Neurophysiology. Science, 160, 1192-1196.

Greeve, I., Kretzschmar, D.,Tschape, J.A., Beyn, A., Brellinger, C., Schweizer, M., Nitsch, R. M., Reifegerste, R. (2004). Age-Dependent Neurodegeneration and Alzheimer-Amyloid Plaque Formation in Transgenic Drosophila. The Journal of Neuroscience, 24 (16): 3899-3906.

Grundke-lqbal, I., Iqbal, K., Tung, Y, Quinlan, M., Wisniewski, H. M., \& Binder, L. I, (1986) (a). Abnormal phosphorylation of the microtubule-associated protein tau in Alzheimer cytoskeletal pathology. Proc. Natl. Acad. Sci. USA 83, 4913-4917.

Grundke-Iqbal, I., Iqbal, K., Quinlan, M., Tung, Y., Zaidi, M. S., \& Wisniewski, H. M. (1986)(b). Microtubule-associated Protein Tau. A component of Alzheimer paired helical filaments. The Journal of Biological Chemistry, 261 (13): 6084-6089.

Gualtieri, M. (2004). Visão de cores e sensibilidade ao contraste em indivíduos com diabete melito: avaliação psicofísica e eletrofisiológica. Dissertação de Mestrado, Instituto Psicologia, Universidade de São Paulo, São Paulo.

Guo, Q., FU, W., Sopher, B. L., Miller, M. W., Ware, C. B., Martin, G. M., \& Mattson, M. P. (12007). Increased vulnerability of hippocampal neurons to excitotoxic necrosis in presenilin-1 mutant knock-in mice. Nature Medicine, 5 (1): 101 - 106. 
Haines, D. C., Chattopadhyay, S. \& Ward, J. M. (2001). Pathology of Aging B6;129 Mice. Toxicologic Pathology, 29 (6) 653-661.

Harazny, J., Scholz, M., Buder, T., Lausen, B., \& Kremers, J. (2009). Electrophysiological deficits in the retina of the DBA/2J mouse. Doc Ophthalmol., 119 (3): 181-197.

Heckenlively, J. R., \& Arden, G. B. Associate editors: Nusinowitz, S., Holder, G. E., \& Bach, M. (2006). Principles and Practice of Clinical Electrophysiology of Vision. $2^{\text {nd }}$ edition. The Mit Press Cambridge, Massachusetts.

Hedrich, H., Bullock, G., \& Petrusz, P. (2004). The handbook of experimental animals. The Laboratory Mouse. Oxford, UK: Elsevier Limited.

Herrera Junior, E., Caramelli, P., Nitrini, R. (1998). Estudo epidemiológico populacional de demência na cidade de Catanduva - estado de São Paulo - Brasil. Revista de Psiquiatria Clínica, 25, 70-73.

Jen, L. S. et al. (1998). Alzheimer's peptide kills cells of retina in vivo. Scientific correspondence Nature, 392, 140 - 141.

Jeon, C. J., Strettoi, E., Masland, R. H. (1998). The Major Cell Population of the Mouse Retina. The Journal of Neuroscience, 18(21): 8936-8946.

Kandel, E. R., Schwartz, J. H., \& Jessell, T. M. (2003). Princípios da neurociência (4ạ Ed.), São Paulo: Manole.

Kidd, M. (1963). Paired helical filaments in electron microscopy of Alzheimer's disease, Nature, 197, 192-193.

LaFerla, F. M., \& Oddo, S. (2005). Alzheimer's disease: AB, tau and synaptic dysfunction. Trends in Molecular Medicine, 11, 4, $170-178$.

Lei, B., Yao, G. , Zhang, K. , Hofeldt, K.JU., Chang, B. (2006). ,Study of rod-and cone-driven oscillatory potentials in mice. Invest. Ophthalmol. Vis. Sci. 47 (6): 2732-2738 
Lin, B, \& Masland, R. H. (2006). Populations of Wide-Field Amacrine Cells in the Mouse Retina. The Journal of Comparative Neurology, 499, 797 - 809.

Lindwall, G., \& Cole, R. D. (1984). Phosphorylation Affects the Ability of Tau Protein to Promote Microtubule Assembly. The Journal of Biological Chemistry, 259, No. 8, 5301 $-5305$.

Löffler, K. U., Edward, D. P., \& Tso, M. O. M. (1995). Immunoreactivity Against Tau, Amyloid Precursor Protein, and Beta-Amyloid in the Human Retina. Investigative Ophthalmology \& Visual Science, 36 (1): $24-31$.

Loo, D. T, Copani, A., Pike, C. J, Whittemore, E. R., \& Walencewicz, A. J. (1993). Apoptosis is induced by B-amyloid in cultured central nervous system neurons. Proc. Natl. Acad. Sci. USA., 90, 7951 - 7955.

Mahley, R. W. (1988). Apolipoprotein E: Cholesterol Transport Protein with Expanding Role in Cell Biology. Science, 240, 622-630.

Marmor, M. F., Holder, G. E., Seeliger, M. W., \& Yamamoto, S. (2008). Standard for clinical electroretinography (2004 update). Documenta Ophthalmologica 108, 107-114.

Matus, A. (1988). Microtubule-Associated Proteins: Their Potential Role in Determining Neuronal Morphology. Ann. Rev. Neurosci. 11, 29-44.

McKinnon, S. J. (2003). Glaucoma: ocular Alzheimer's disease? Frontiers Bioscience, 11401156.

Möller, H. J., \& Graeber, M. B. (1998). The case described by Alois Alzheimer in 1911 Historical and conceptual perspectives based on the clinical record and neurohistological sections. Eur. Arch. Psychiatry Clin. Neurosci., 248, 111 - 122.

Morin, P. J., Abraham, C. R., Amaratunga, A., Johnson, R. J., Huber,G., Sandell, J. H., \& Fine, R. E. (1993). Amyloid Precursor Protein Is Synthesized by Retinal Ganglion Cells, Rapidly 
Transported to the Optic Nerve Plasma Membrane and Nerve Terminals, and Metabolized. J. Neurochem., 6 (2): 464 -473.

Nee, L. E., et al (1987). Dementia of the Alzheimer type: clinical and family study of 22 twin pairs. Neurology; 37, 359-363.

Ning, A., Cui, J., To, E., Ashe, K. H., \& Matsubara, J. (2008). Amyloid-B Deposits Lead to Retinal Degeneration in a Mouse Model of Alzheimer Disease. Investigative Ophthalmology \& Visual Science, 49 (11): 5136 - 5143.

Nitrini, R. (1999). Epidemiologia da doença de Alzheimer do Brasil. Revista de Psiquiatria Clínica 26 (5).

Nitrini, R. (2005) (a). Critérios diagnósticos e exames complementares. Recomendações do Departamento Científico de Neurologia Cognitiva e do Envelhecimento da Academia Brasileira de Neurologia. Arq NeurOPiquiatr. 63(3-A): 713-719.

Nitrini, R. (2005) (b). Diagnóstico de doença de Alzheimer no Brasil. Avaliação cognitiva e funcional. Recomendações do Departamento Científico de Neurologia Cognitiva e do Envelhecimento da Academia Brasileira de Neurologia Arq. NeurOPiquiatr. 63(3-A): 720-727.

Oddo, S., Caccamo, A., Shepherd, J. D., Murphy, M. P., Golde, T. E., Kayed, R., Metherate, R., Mattson, M. P., Akbari Y., LaFerla, F. K. (2003). Triple-Transgenic Model of Alzheimer's Disease with Plaques and Tangles: Intracellular AB and Synaptic Dysfunction. Neuron, $39,409-421$.

Parks, R. W., Zec, R. F., \& Wilson, R., S. (1993). NeurOPychology of Alzheimer's Disease and Other Dementias. Nova York: Oxford University Press.

Pache, M et al (2003). Colour vision deficiencies in Alzheimer's disease. Age and Ageing, 32, $422-426$. 
Pereira, J. M., Mendieta, L., Sacai, P. Y., Salomão, S. R., Berezovsky, A. (2003). Estudo normativo do eletrorretinograma de campo total em adultos jovens. Arq Bras Oftalmol. 66, $137-144$.

Perez, S. A., Lumayag, S., Kovacs, B., Mufson, E. J., \& Xu, S. (2009). B-Amyloid Deposition and Functional Impairment in the Retina of the APPswe/PS1deltaE9 Transgenic Mouse Model of Alzheimer's Disease. Investigative Ophthalmology \& Visual Science, 50 (2): $793-800$.

Pessôa, C. N., Santiago,L. A., Santiago,D. A., Machado,D. S., Rocha,F. A. F., Ventura,D. F., Hoko,J. N., Pazos-Moura,C. C., Wondisford,F. E., Gardino,P. F., \& Ortiga-Carvalho, T. M. (2008). Thyroid Hormone Action Is Required for Normal Cone OPin Expression during Mouse Retinal Development. Investigative Ophthalmology and Visual Science, 49, 2039-2045.

Qian, S. et al.(2998) Mutant human presenilin 1 protects presenilin 1 null mouse against embryonic lethality and elevates A $A 1-42 / 43$ expression. Neuron 20, 611-617.

Rakoczy, P. E., Yu, M. J. T., Nusinowitz, S., Chang, B., Heckenlively, J. R. (2006). Review: Mouse models of age-related macular degeneration. Experimental Eye Research, 82, $741-752$

Reynolds, A. L.,Danciger, M, Farrar, G. J., Humphries, P., \& Kenna, P. F (2008). Influence of a Quantitative Trait Locus on Mouse Chromosome 19 to the Light-Adapted Electroretinogram. Investigative Ophthalmology \& Visual Science, 49 (9): 4058-4063.

Rohn, T. T., Vyas, V., Estrada, T. H., Nichol, K. E., Christie, L. A., \& Head, E. (2008). Lack of Pathology in A triple Transgenic Mouse Model of Alzheimer's Disease after Over expression of the Anti ApoptoticProteinBcl-2. The Journal of Neuroscience, 28 (12): 3051-3059.

Saszik, S. M., Robson, J. G., \& Frishman, L. J. (2002). The scotopic threshold response of the dark-adapted electroretinogram of the mouse. J. Physiol. 543; 899-916. 
Schuettauf, T. et al, Retinal neurodegeneration in the DBA /2J mouse model for ocular hypertension, Acta Neuropathol 107 : 352 -358, 2004.

Schweers, O., Schonbrunn-Hanebeck, E., Man, A., \& Mandelkow, E. (1994). Structural studies of tau protein and Alzheimer paired helical filaments show no evidence for bstructure. The Journal of Biological Chemistry, 269 (39): 24290-24297.

Seubert, P. et al (1993). Secretion of B-amyloid precursor protein cleaved at the amino terminus of the 6-amyloid peptide. Nature, 361, 260-263.

Shen, J. , Bronson, R. T., Chen, D. F., Xia, W., Selkoe, D. J., \& Susumu Tonegawa. (1997). Skeletal and CNS defects in Presenilin-1-deficient mice. Cell 89,629-639.

Shoji, M. et al (1992). Production of the Alzheimer amyloid 8 protein by normal proteolytic processing. Science, 258, 126-129.

Souza, G. S.; Gomes, B. D.; Silveira, L. C. L.(2010) Métodos de processamento de dados em eletrofisiologia visual: tutorial de linguagem MATLAB sobre o uso da transformada de Fourier na análise do potencial cortical provocado visual. Neurociências (Rio de Janeiro), v. 6, p. 39-49.

Terry, R. D., Katzman, R., \& Bick, K. L. (1994). Alzheimer Disease. Nova York: Raven Press.

Tezel, G., Oxidative stress in glaucomatous neurodegeneration: mechanisms and consequences, Prog Retin Eye Res. Sep;25(5):490-513, 2006

Valenti D. A. (2010). Alzheimer's disease: visual system review. Optometry. 81(1):12-21.

Ventura, D. F., Costa, M. T. V.,Costa, M. F., Berezovsky, A., Salomão, S. R., Simões, A. L., Lago, M., Pereira, L. H. M. C., Faria, M. A. M., de Souza, J. M., \& Silveira, L. C. L. (2004). Multifocal and full-field electroretinogram changes associated with color-vision loss in mercury vapor exposure. Visual Neuroscience, 21, (3): 421-429. 
Ventura, D. F., \& Hamassaki, D. (2005). Neurônios da Retina. In: Hernandes F. Carvalho; Carla Beatriz Collares-Busato. (Org.). Células: uma abordagem multidisciplinar, 278-290. São Paulo: Editora Manole.

Yasuda, C., Ueno, S., Kondo, M., Chang-Hua Piao, Terasaki, H. (2010). Analyses of ERG in a patient with intraocular lymphoma. Clinical Ophthalmology,4, 301-306.

Yuan, J. (1997). Transducing signals of life and death. Current Opinion in Cell Biology, 9, 247251.

Wachtmeister, L. (1998). Oscillatory Potencials in the Retina: what do they reveal. Progress in Retinal and Eye Research, 17 (4): $485-521$.

Watson, J. D., Baker, T. A, Bellm S. P., Gann, A., Levine, M., \& Losick R. (2006). Biologia molecular do gene. 5a edição. Porto Alegre : Artmed

Williams, R. W., Strom, R. C., Zhou, G., \& Yan, Z. (1998). Genetic dissection of retinal development. Cell e Developmental Biology, 9, 249-255.

\subsection{Sites}

http://www.ibge.gov.br (Acessado em 10 de abril de 2010)

Deste site foram retirados dados do trabalho de Cintra, M. T. G., Belém, D., Moraes, F. L., Moraes, E. N. Avaliação do Programa Público Brasileiro de Tratamento da Doença de Alzheimer, no ano de 2008.

http://neuropathology.neoucom.edu/chapter9/chapter9bAD.html (Acessado em 14 de abril de 2010 